Historic, archived document

Do not assume content reflects current scientific knowledge, policies, or practices. 



\section{the most EXCITING}

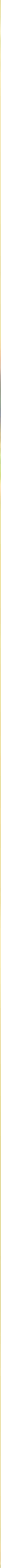

GERMAIN'S

SEED GROWERS AND HORTICULTURISTS INCE I 87 I 


\section{ALL AMERICA Rase Winner1 for 1952}

ALL ITEMS POSTPAID

NO C. O. D. ORDERS

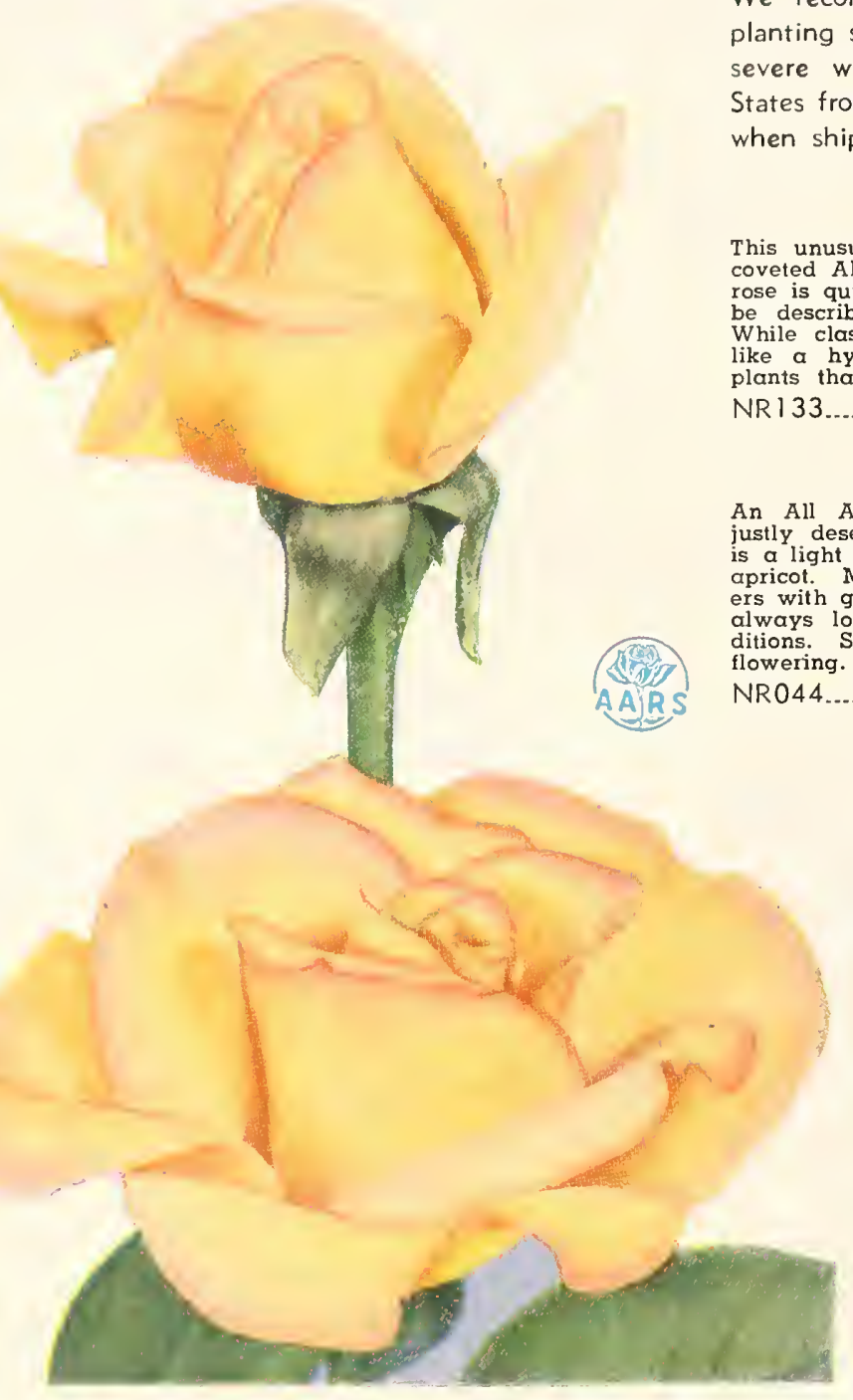

FRED HOWARD Pat. 1006)

FRED HOWARD (Pat. 1006). The long, rich yellow buds are tipped with a delicate penciling of light pink, and when the buds open you see full double, high centered, beautifully formed flower. The plant is strong, hardy and clothed in dark,
cellent for cutting. All America Award for 1952 .

NR027.

$\$ 2.75$ each, 3 for $\$ 7.20$

BABY CHATEAU Semi-double flowers of deep velvety red, borne in large clusters. Very free flowering and fine for bedding.

NR002 $\ldots \ldots$ each, 3 for $\$ 3.25$

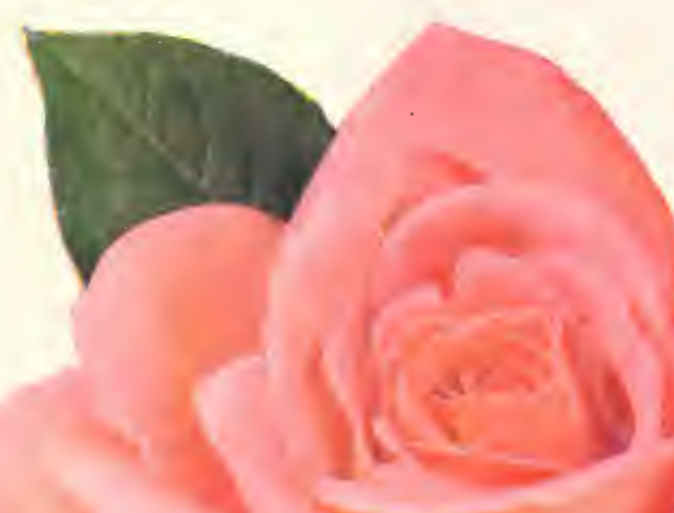

R 133

HELEN

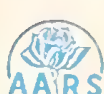

A A RS
We recommend shipment at the proper anting season in Spring to all States with winters but can ship to Southern from December on. Please designate

\section{VOGUE}

is unusual floribunda type rose received the All America Award for 1952. No other is quite this color. We believe it can best as a vivid deep coral scarlet. a loribunda, if really looks ants that are very free flowering.

$\$ 2.25$ each, 3 for $\$ 6.00$

\section{HELEN TRAUBEL
(Pat. Applied For)}

All America Winner for 1952. This rose lige color Magnificent buds, and half a lum flowwith glous full open blooms. The flowers gok clean regardless of weather conStrong growing plant that is very free

$\$ 2.75$ each, 3 for $\$ 7.20$

\section{CAPISTRANO}

The outstanding All America Rose Winner of a decade in vigor of growth and beauty or color. Beautiful long ry-red open to immense cherry-red open to immense long clear sparkling rose-pink. Capistrano produces lorge quantities of gorgeous blooms all season long and will truly be the treasure of your rose garden. All America $A$ ward Winner for 1950.

NR007.

$\$ 2.25$ each,
3 for $\$ 6.00$

\section{CHRISTOPHER}

\section{STONE}

Lovely, long-pointed buds open to vivid scarlet blooms with a dusky nap of crim-

$$
\begin{array}{r}
\text { son. } \\
\text { NR008 } \$ 1.25 \text { each, } \\
3 \text { for } \$ 3.25
\end{array}
$$

\section{CONDESSA DE SASTAGO}

Brilliantly Spanish in coloring. The petals are two-toned, goep outside. copper-rose and scarlet on the interior. NR009 \$1.25 each, 3 for $\$ 3.25$

\section{COUNTESS VANDAL}

Long pointed bud, distinctive shading of coppery bronze, suffused with soft gold. its beauty and abundant bloom. NR010 $\$ 1.25$ each, 3 for (Pat. App. For)

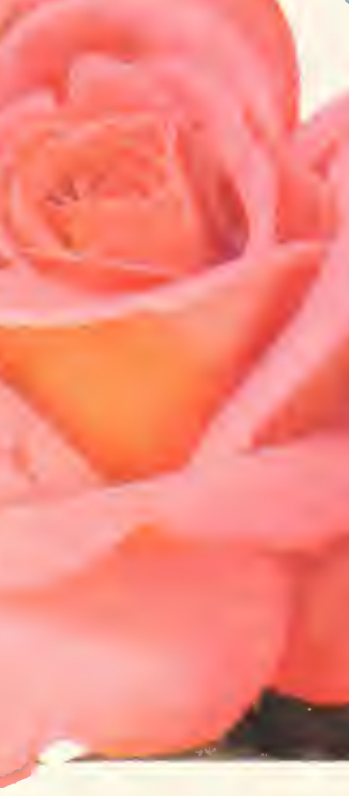

\section{DUQUESSA DE}

Orange apricot with deeper coppery tones. Huge pointed NR019

\section{$\$ 1.25$ each} perfumed, long-lasting.
VOGUE (Pat. 926)

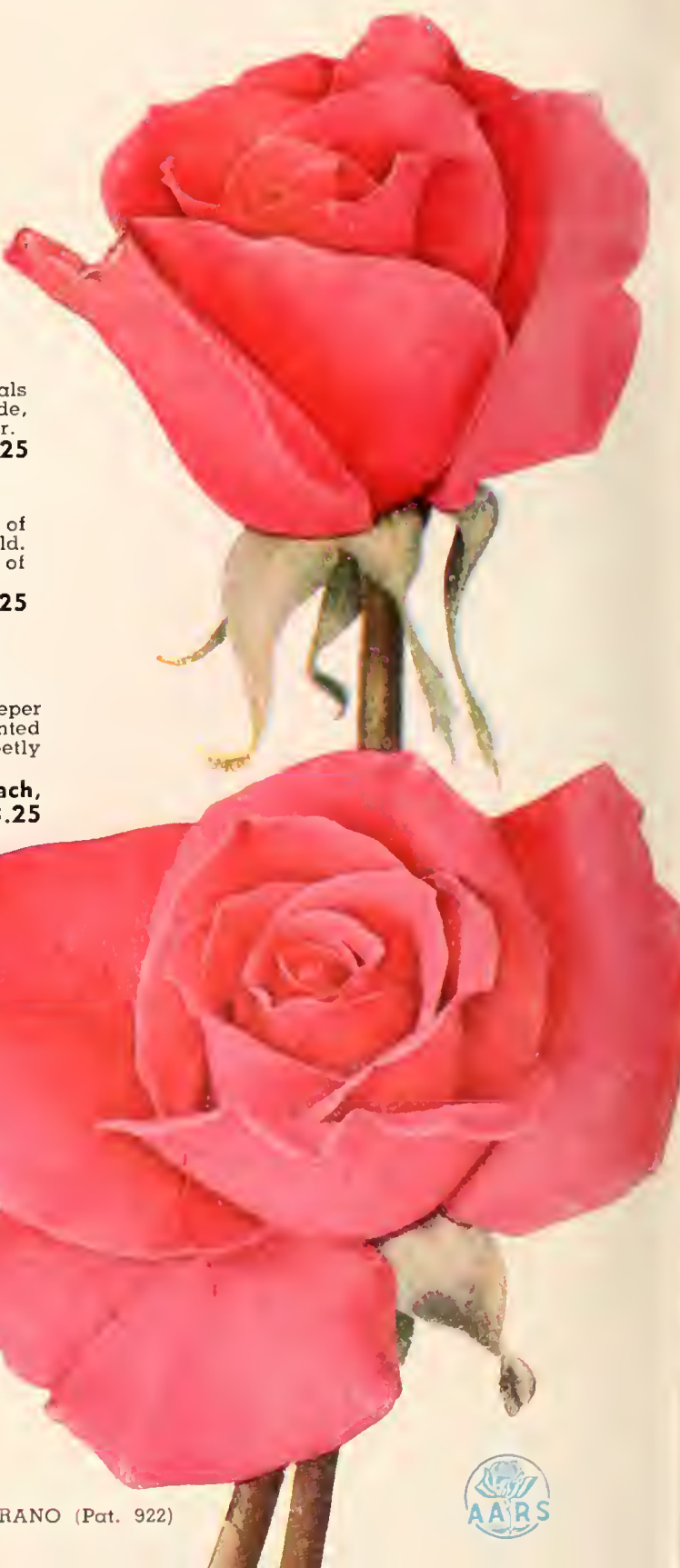




\section{CLIMBING ROSES}

\section{For Trellises, Arbars and Fences}

CL. BELLE OF PORTUGAL Large pearl pink blooms of unusual beauty. cific Coast and Southern States only.

NR 150_\$1.25 ea., 3 for $\$ 3.25$

CL. BEST REGARDS (P.R.R.) Cardinal red and tyrian rose flowers of enormous NR151...\$1.50 ea., 3 for $\$ 3.75$

CL. BLAZE An everblooming Paul's Scorlet. Blooms vivid scarlet produced in

NR 152...\$1.25 ea., 3 for $\$ 3.25$

CL. CAPISTRANO Strong growing of clear rose pink. Delicious fragrance. NR153..\$2.00 ea., 3 for $\$ 5.25$
CL. CECIL BRUNER Salmon flowers of small size produced profusely on ampant growing climber.

NR154 ...\$1.25 ea., 3 for $\$ 3.25$

CL. COUNTESS VANDAL We re gard this variety as one of the fines copper and gold tones.

NR 157_...\$1.25 ea., 3 for $\$ 3.25$

CL. CRIMSON GLORY (Pat. 736) C a strong growing plant. Fragrant.

NR 158...\$2.00 ea., 3 for $\$ 5.25$

CL. SAN FERNANDO

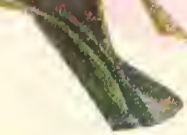

CL. HEART'S DESIRE (Pat. 663). Great dark red blooms of fine form and texture. Vigorous NR $169 \ldots \ldots \ldots \ldots 1.75$ ea., 3 for $\$ 4.65$

CL. HIGH NOON (Pat. 704). An intense shade Glossy foliage. Almost thorn less flower stems. Pillar type.

NR170 ............. $\$ 2.00$ ea., 3 for $\$ 5.25$

CL. K. A. VICTORIA Plants bloom through out the season. The lovely white flowers are mag

$\$ 1.25$ ea., 3 for $\$ 3.25$

CL. MRS. E. P. THOM Deep lemon yellow wers with fine dark green foliage.
NR176
$\$ 1.25$ ea., 3 for $\$ 3.25$

CL. Mrs. SAM MEGREDY (Pat. 374). Out standing for its coppery orange flowers and buds.
Blooms profusely the first year after planting. NR178 _...... $\$ 1.75$ ea., 3 for $\$ 4.65$

CL. PEACE (Pat. 932). A new climber, but most outstanding. Large canary yellow buds open to cerise edges.

NR 182

$\$ 2.50$ ea., 3 for $\$ 6.60$
CL. PICTURE (Pat. 524). Flowers of clear pink

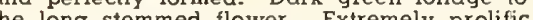

NR 183

$\$ 1.75$ ea., 3 for $\$ 4.65$

CL. PRES. HOOVER A vigorous climber. A combination of colors: cerise pink, flame scarlet and NR 185

$\$ 1.25$ ea., 3 for $\$ 3.25$

CL. ROSE MARIE Pure rose pink flowers.

CL. SAN FERNANDO (P.A.F.) A climbing form of the All America Award Winner. Has the same currant red color and exquisite fragrance o the bush type. Makes a brilliant show on a fence NR 186

$\$ 2.00$ ea., 3 for $\$ 5.25$

CL. TALISMAN A combination of shadings of gold, apricot yellow, deep pink and old rose. The NRI 89.............\$1.25 ea., 3 for $\$ 3.25$ CL. TEXAS CENTENNIAL (Pat. 565). Glow ing carmine red flowers on long stems. A vigorous climber. NR $187 \ldots \ldots . . . . .11 .25$ ea., 3 for $\$ 3.25$

$\$ 1.75$ ea., 3 for $\$ 4.65$

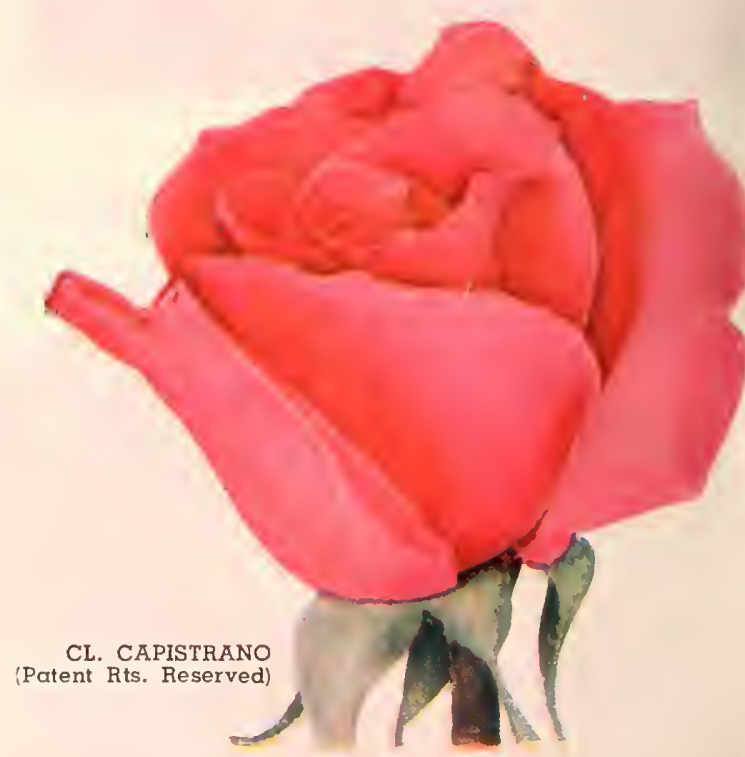

\section{YOU SAVE WHEN YOU BUY OUR COLLECTIONS}

\section{THE BIG SIX COLLECTION}

One of the finest collections you can plant in your garden. ONE EACH OF AMIGO, BEST REGARDS, SAN FERNANDO, SAN GABRIEL,

Collection Complete: $\$ 8.50$ (A $\$ 9.75$ Value)

\section{GERMAIN'S 12 PATENTED ROSES}

welve outstanding patented roses that will give you all colors known to roses.

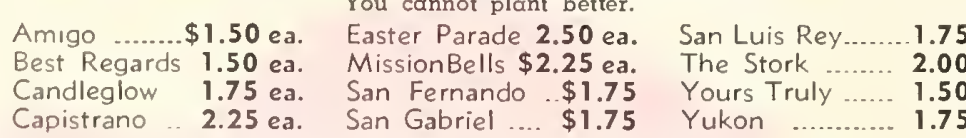
Complete Collection of All 12 Germain's Patented Roses; a $\$ 22.25$ Value for $\$ 18.95$

THE FAMOUS MISSION TRIO

ONE EACH OF SAN FERNANDO, SAN GABRIEL, SAN LUIS REY A $\$ 5.25$ Value for $\$ 4.65$

\section{ALL AMERICA AWARD WINNER COLLECTION}

collection of four roses that will make your garden complete and modern tomorrow. These outstanding varieties were selected from Test Gardens and free flowering qualities.

One Each of the All America Awards Winners for 1951

CAPISTRANO - Luminous Rose Pink

$\$ 2.25$ ea. MISSION BELLS-Salmon and Shrimp Pink

ea.

\section{A Complete Rose Garden}

GERMAIN'S 1952 FAMOUS DOZEN COLLECTION

One Each of the Following Varieties (A $\$ 15.00$ Value) for $\$ 12.95$

Coundessa de Sastago Mrs. E. P. Thom Sister Therese

Countess Vandal Night $\quad$ Snowbird

$\begin{array}{ll}\text { Duquessa de Peneranda } & \text { Picture } \\ \text { Etoile de Holland } & \text { President Hoover The Doctor }\end{array}$

\section{A.A.R.S. BEST TEN COLLECTION}

This Collection was selected by the All America Selections Committee as the roses given the coveted All America Awardion

CHARLOTTE ARMSTRONG (Pat. 455)_Flaming Cerise............ \$2.00

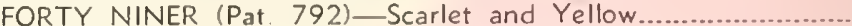
KATHERINE T. MARSHALL (Pat, 607) _Glowing Clear Pink..... 1.75 LOWELL THOMAS (Pat. 664)_Chrome Yellow..................... 2.00 MIRANDY (Pat. 632)—Dark Crimson................................................... NOCTURNE (Pat. 713)_Deep Red..................................... 1.75 PEACE (Pat, 591)_Yellow edged Pink _

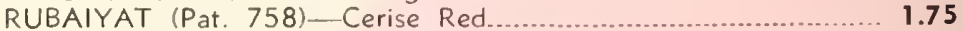
SAN FERNANDO (Pat. 785) —Currant Red................................. 1.75 TALLYHO (Pat. 828) - Two tone Red. (A $\$ 19.25$ Value) COLLECTION PRICE-\$16.75 YOU SAVE OVER $12 \%$

\section{ALL AMERICA AWARD WINNER COLLECTION}

The 1952 award winners judged the best by the Rose jury of the All America Rose Selections Committee. Have in your garden the latest and finest sorts. These varieties do well in all parts of the country. This has been proven an

FRED HOWARD-Yellow edged pink $\$ 2.75$ ea. .

VOGUE-Deep coral scarlet................... 


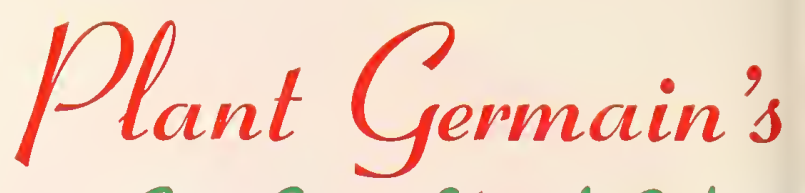
Far Gay, Vivid Calars

\section{No C. O. D. Orders}

NPI0I SANTA MONICA (1)-Beautiful light pink shade, large flowers. NP102 MACKENSEN (2)_-Fiery rose color. Compact grower.

NP103 MARIE VOGEL (3)-Pink and salmon shades, very large flowers. NPIO4 DUCHESS OF CORNWALL (4)-Deep maroon with silvery edges. NP105 MARY BARD (5)_Pure white with rose markings at the throat. NP106 SALMON QUEEN (6)—Very free flowering, salmon pink, white throat.

NPI07 SAN DIEGO (7)-Light purple with black blotches on each petal. NP108 SPRINGTIME (8)-Fiery salmon markings on a white ground.

NPI09 EASTER GREETING (9) - The earliest to bloom. Color bright red. NPI 10 PINK GIANT (10)-Large flowers of clear pink. (Not pictured). NPIII BELLA DONNA (11)-Cerise pink, blotched upper petal. (Not pictured).

NP112 SUE JARRETT (12)—One of the finest salmon shades. (Not pictured).

Any of the above 3 for $\$ 1.60$

$\$ 5.50$ per dozen Postpaid in U. S. A. Only

\section{GLORIOUS NEW}

The choice of the new varieties brought out in the past few Seasons. Can be grown as pot plants or

BALLERINA Shell pink upper petals veined deep red. Large ruf-
NP1 25

CONSPICUOUS Shining oxblood red waved petals, edqed with black hair.

GAY NINETIES $W$ a $v y$ petals of glistening white with elonqated rosy
spot in lower petals. NP127

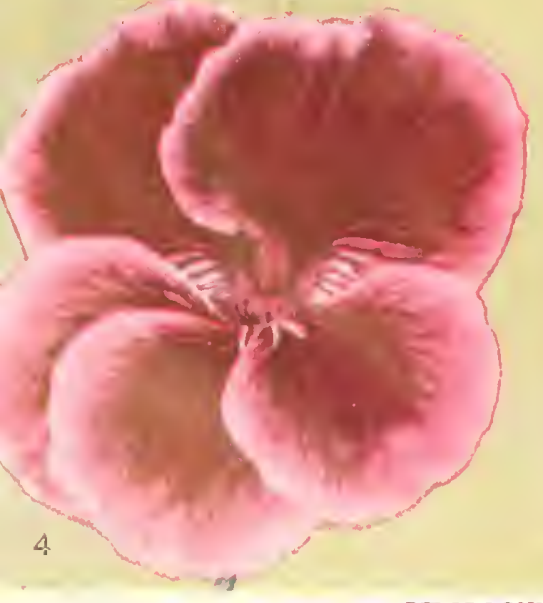

PELARGONIUMS

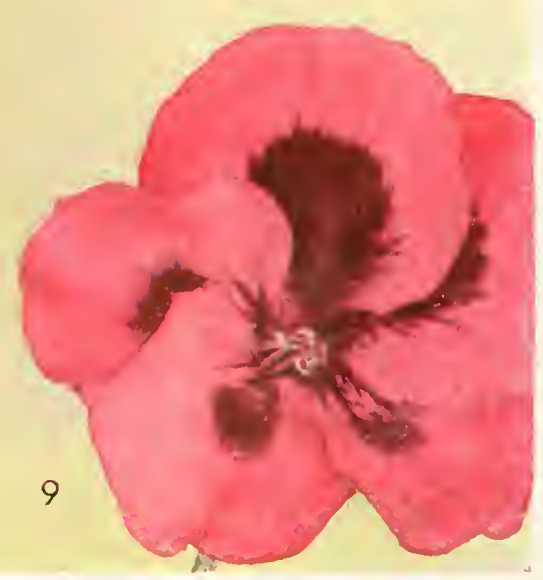

FANCIER'S IRIS COLLECTION If you are an Inis fancier, this collection is for you. The newest varieties, at greatly reduced prices. Read and compare our Cascade Splendor-Pink

apricot, $\tan \ldots . . . . . . . . . .50 \mathrm{ea}$ Chivalry - Medium blue..... $5.00 \mathrm{ea}$ Cordovan-Brown red .......... 2.50 ea. Golden Ruffles-Ruffled

Yellow $\$ 4.50 \mathrm{ea}$ Pink Cameo-Flamingo pink 4.00 ea. Rocket-Orange chrome.... $6.00 \mathrm{ea}$

\section{Epidendrums}

This orchid makes a grand showing outdoors in frostless sections or as a house plant in cold climates. Soil should be well drained with plenty of leaf mold added. Water moderately. Shade loving.

\section{APRICOT GLOW A n e w} rariety that is a qrand shade al alowing apricot. Free flow ering and easy to grow. $\mathrm{N} \times 504 \quad \$ 2.00$ each

BRACEYII The largest flow ered of all the Epidendrums. Color is a bright Orange Scar et. The plant is more compact han any other variety, th larqe.

NX506

$\$ 2.50$ each

BURTONI This variety is be inq offered by us for the firs the. growna varient showy and free flowering. $\mathrm{N} \times 503$............\$2.00 each

LAVENDER BEAUTY A new color in the popular free-flow ening orchid, a beautiful shade please.

NX505

$\$ 2.00$ each

O'BRIENIANUM This variety is probably the most widely dis tributed of all Epidendrums. Its exciting crimson
JUNGLE NIGHT Reddish bu $\mathrm{d} s$ darkening to black. Open flower wavy patch. MARDI GRAS White, lower petals feathered at base violet rose, top petals striped and blotched viole rose. NP129 PRAIRIE FIRE Sof $\mathrm{t}$ in $\mathrm{k}$ and orange salmon. Lower petals veined deep brown. Remarkable for its flame-
like color flowers.

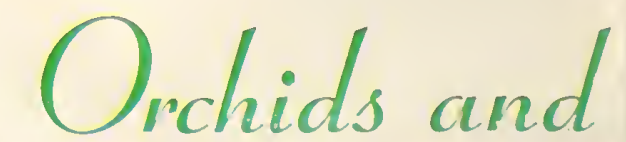

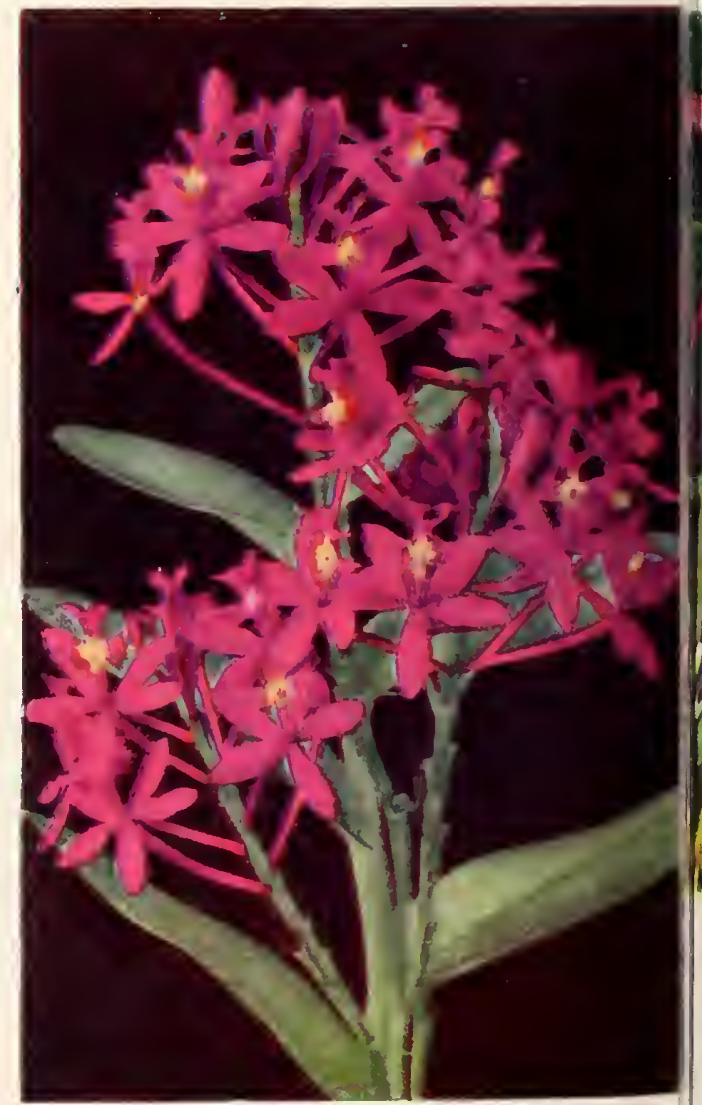

L.AVENDER BEAUTY EPIDENDRUM

RADICANS welcome addition to this class of plant is the Radicans. The color is a very brilliant red and this variety is exceptionally free flowering.

NX509

$\$ 2.00$ each 


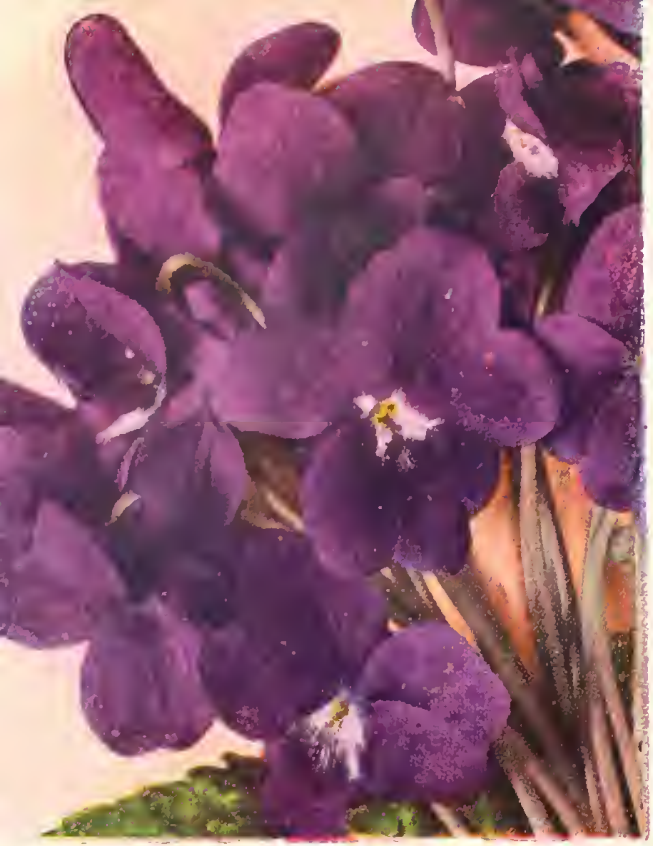

ROYAL ROBE
Fragrant Lang-Stem Vialets

VIOLET ROYAL ROBE Never before have you seen such deep-lustrous violet blue color, such delicate petals that open such luscious scent-the very essence of fragrant voilet per NP167.......................... for $\$ 1.25 ; 10$ for $\$ 3.75$ NEW VIOLET BLUE GIANT A lustrous shade of blue which is very eye appealing. The center has a distinct white

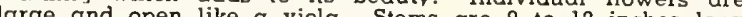
on well grown plants. Fragrance is the most deliqhtful of violet perfumes.

NPI 64.

3 for $\$ 1.25 ; 10$ for $\$ 3.75$

FREY'S FRAGRANT Color is vivid deep blue. Deep fragrance. Foliage is large, stems are long and flowers held wP165

\section{VIOLET COLLECTION}

1 each of the three varieties listed above NP1 68.......................\$1.25

ASTER FRIKARTI This sensational new large flower perennial Aster blooms from late Spring until frost. Its clear lavender-blue flowers which are yellow-centered are exceedingly showy. A compact growing plant that does equally well in the sun or half
useful for cutting. NP006.

GERBERAS An excellent garden plant and at the same time one of the most beau. tiful of cut flowers. Extra large size in sal. mons, pinks, reds, yellows and their varia. tions. Borne on long, wiry stems, ideal for cutting and keep easiy should be lifted after cold climates gerberas shou bool place until the first frost and stored in a coold when the soil warms up in the Spring. When planting, care should be taken to keep the
crown of the plant above the surface of the soil. Sold in mixture only. NP067....3 for $\$ 1.65 ; 12$ for $\$ 5.95$ POLYANTHUS - ENGLISH PRIMROSE Among the most useful and beautiful plants to qrow in shady places or in pots. Primroses provide color all through spring and early summer. Polyanthus is one of our leading shade-loving plants. Colors white and combinations of these colors. Sold in mixtures only, not by colors.
NP084...3 for $\$ 1.45 ; i 2$ for $\$ 5.00$ Daisies for Lovely Cut Flowers

CHIFFON Lovely semi-double flowers showing $a$ golden center. Petals are beuutifully waved and frilled at the edges, giving the flower a soft airy appearance. A favorite florist's flower, for corsages and bowl arNP156...3 for $\$ 1.35 ; 10$ for $\$ 4.00$ MARCONI DAISIES Great $s \mathrm{~h} a \mathrm{~g} g \mathrm{y}$ flowers four inches across that make a beau. tiful showing and are indispensable in the cut flower garden. Stems are often two and one half leet long. Color is snow white with NP159...3 for $\$ 1.35 ; 10$ for $\$ 4.00$ THE NEW MAJESTIC DAISY grandest daisy introduced in recent years. The white flowers are enormous in size, measuring five inches across. Two rows set off by the handsome yellow cushion and ruffled edqed petals. $60 \mathrm{c}$ ea.; 3 for $\$ 1.60$ 10 for $\$ 4.75$

ESTHER REED DAISIES The blooms are pure white and completely double and are produced in large quantities from June to November. The plants are vigorous and free flowering and produce the blossoms on tall erect stems. This variety has found fa vor in the East and large quantities Bound to be a favorite in your cut flower NPl60 3 for $\$ 1.25 ; 10$ for $\$ 3.75$

\section{GERMAIN'S NEW}

Daisy Mume

All the sterling qualities which made the double Shasta Daisy a tavorite with leadin florists, and a best seller on the cut flower market, are enhanced and intensified in the main's New Daisy Mum. The blooms are snow white and fully double to the ver Plants grow much more vigorol than most daisies and have heavier foliage.

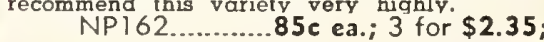

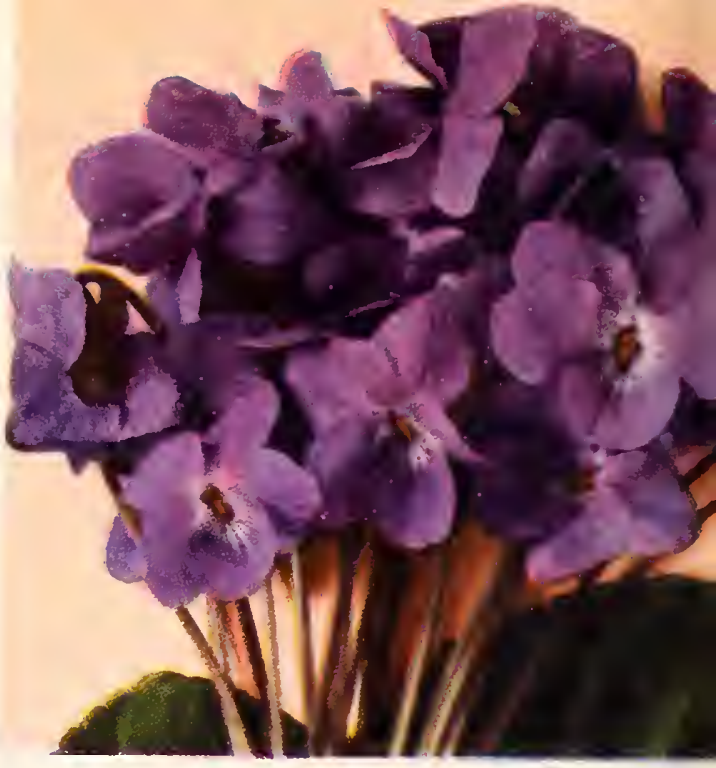

BLUE GIANT

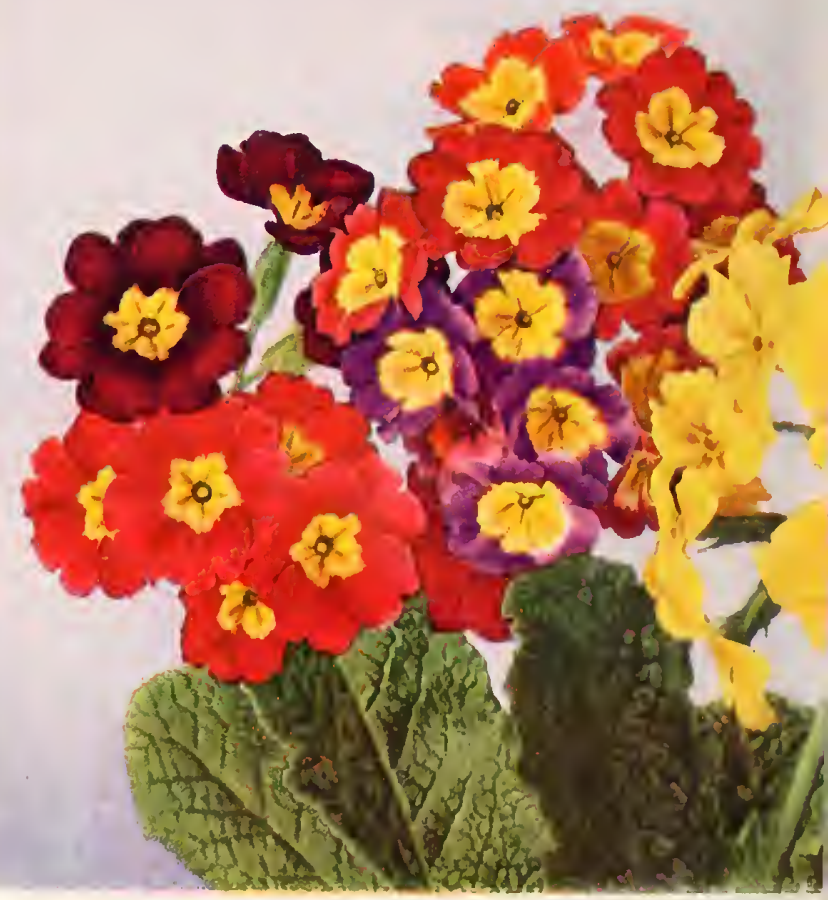

ENGLISH PRIMROSE

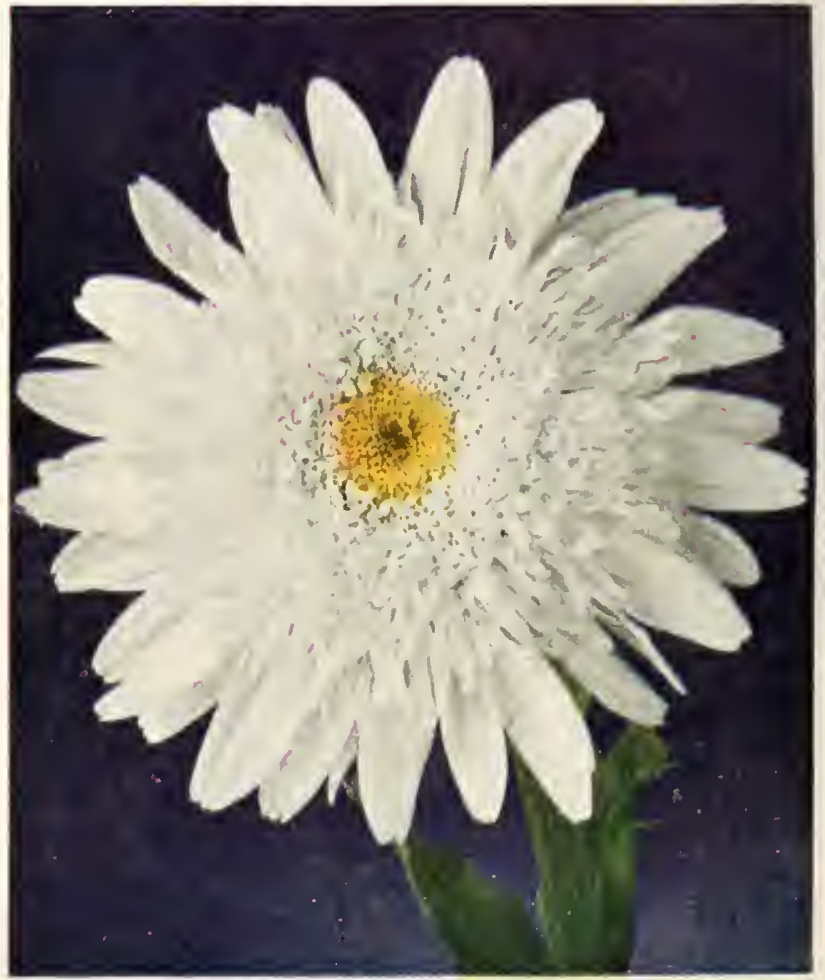

DAISY MUM 


\section{ORDER BLANK FOR PLANTS}

\section{GERMAIN'S}

LOS ANGELES 21, CALIFORNIA

\section{Date of Order}

Mr.

Mrs.

Miss

R. D. or Street and No.

Post Office

State

Express Office

If Difforent from P. O.
Please write your name plalnly and give address in full.

SPRING

Terms-Send Remittance in full with order. We cannot accept c. O orders. All shipments are sent PREPAID.

You pay nothing extra.

19 merchandise is to be sent to another address. please print or write plainly.

SHIP TO

Name.

Address.

Clty and

State................

In case we are out of a variety you order, we shall send another variety of the same color and equal or higher value, as most of our customers prefor it. If you do NOT wish us to substitute, please mark " $x$ " In this space.

NON-WARRANTY. Germain's Inc. gives no warranty express or implied, as to the productiveness of seeds, bulbs or plants tt selis and will not be in ang way responsible for the crop. Our liabtitty in ait instances is intted to the purchase price of the seeds, butbs or plants.

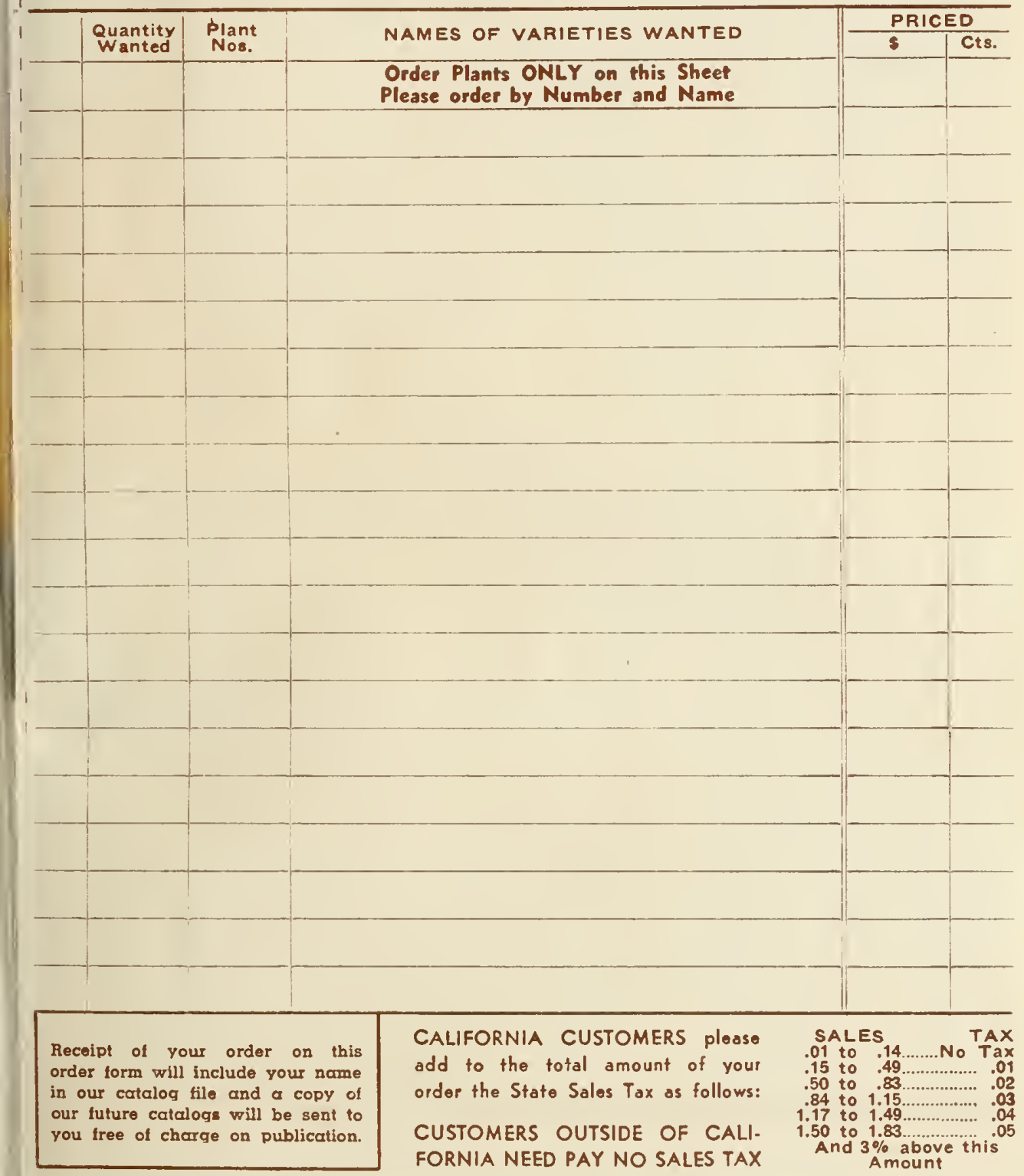




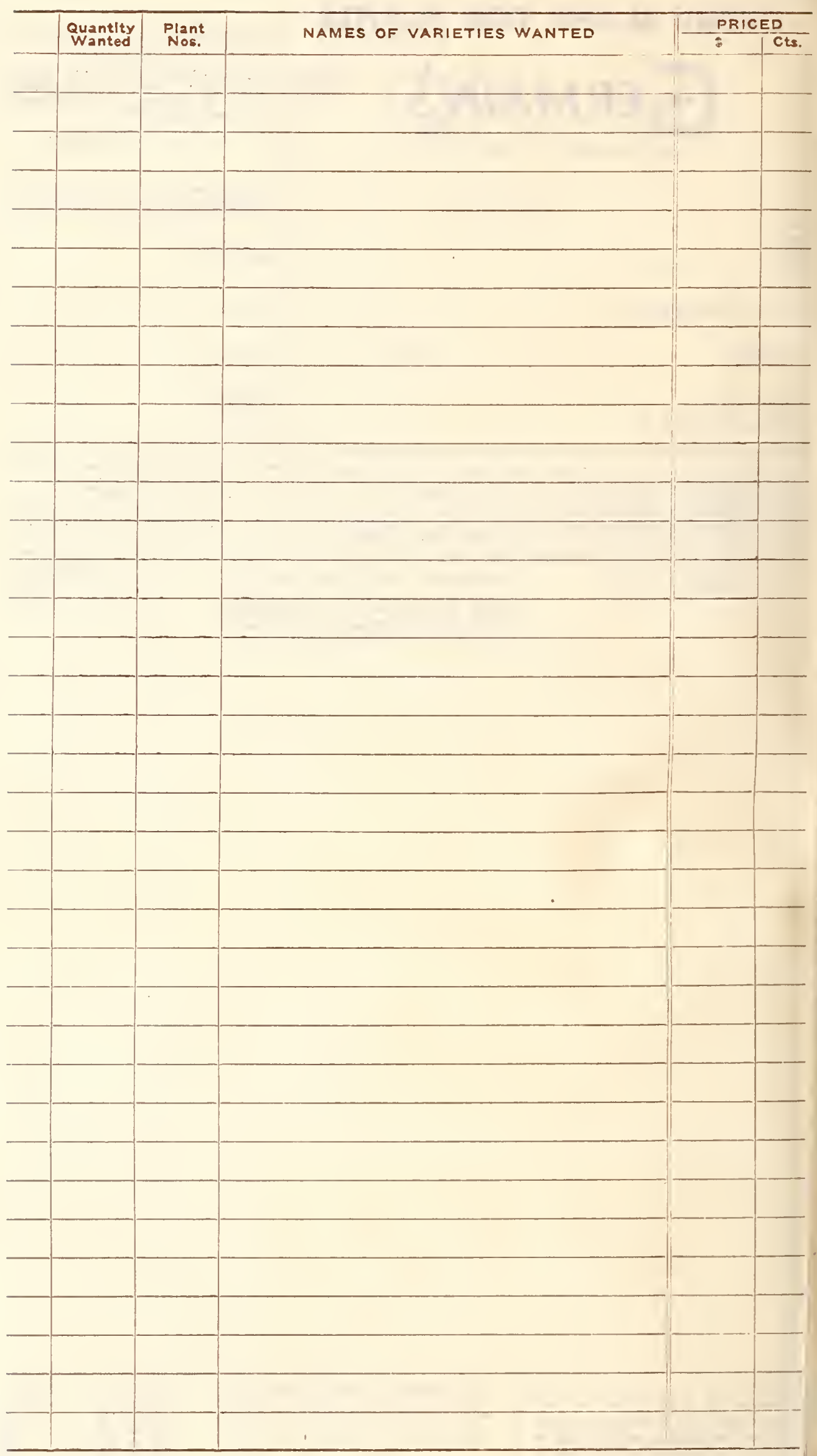




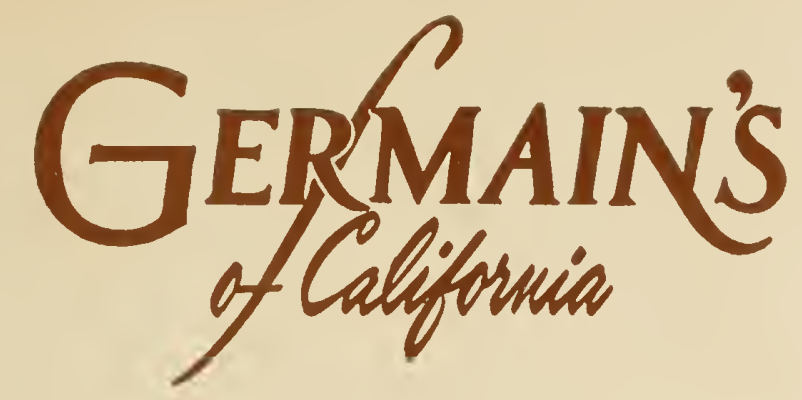

\section{A California Instifution With a National Clientele}

TN 1871, The Germain Seed and Plant Company was founded in the City of Los Angeles-one of the few pioneer firms in this city that can boast of three quarters of a century of continued progress and expansion. From a small retail store, it has become a National and lnternational institution, shipping its products throughout the United States and to many foreign countries.

Germain's ultra-modern Retail establishment in Los Angeles' downtown business district is among the finest in America. No one should fail to visit it when in Los Angeles.

Branches patterned after the Los Angeles store are located in the following California communities: San Francisco, San Diego, Santa Maria, San Jose, Fresno, Compton, Salinas, El Monte, Watsonville, Sacramento, and Van Nuys and in Phoenix, Ariz.

At our nurseries, many acres of lath and greenhouses are devoted to the culture of orchids, flowering and foliage plants, roses and perennials Thousands of acres in the West are devoted to the production of Germain's seeds, plants and bulbs-and are supervised by men thoroughly trained in the Horticultural profession.

This, perhaps explains why more gardeners all over America are planting Germain's seeds and horticultural products each year.

\section{You'll Want to Get Your ROSES, SEEDS, BULBS Direct from California}

\section{- the greatest flower growing center in the nation and as far as we}

know, the World. We are sure that you cannot start your garden year under better auspices than by ordering California Flower Seeds, plants and bulbs from Germain's.

\section{WE PREPAY AND GUARANTEE DELIVERY ANYWHERE IN THE UNITED STATES}

All prices quoted in this catalogue include special packing and carrying charges to any point in the U. S. A. Our experts employ specialized packing methods to protect live plants in transit and assure safe delivery to your door All shipments are sent prepaid. You pay no more than the prices shown.

\section{WHEN MAILING US YOUR ORDER}

use the order sheet enclosed in catalogue, if possible. In the space reserved for address write plainly your name, post office, nearest express office (if different from post office), County and State. Keep a duplicate copy of your order for comparison.

\section{REMITTANCES}

Remittances may be made by Money Order, Bank Draft or Personal Check. If you remit in cash be sure to send in a Registered letter. Please send remittance in full with your order as we do not send shipments C. O. D.

\section{PROMPT SHIPMENTS OF ORDERS}

All orders entrusted to us will be carefully filled and shipped promptly or at the proper planting time. We take every precaution to supply only Plants, Bulbs and Seeds of the highest quality and guarantee safe delivery.
-

-

-

-

\section{Germain's Inc., Los Angeles 21. Californic}

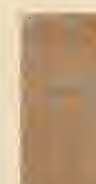

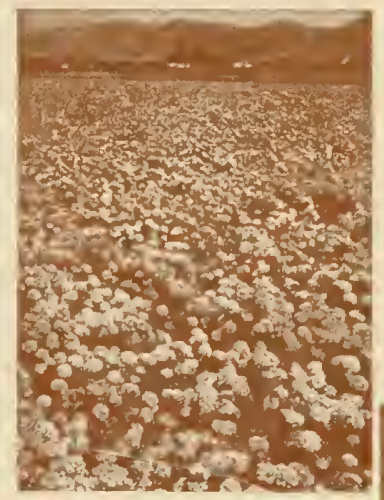

Field View at

seed

Germain's

Fine Flower

Seeds are

grown

View of Salesroom at one of Germain's

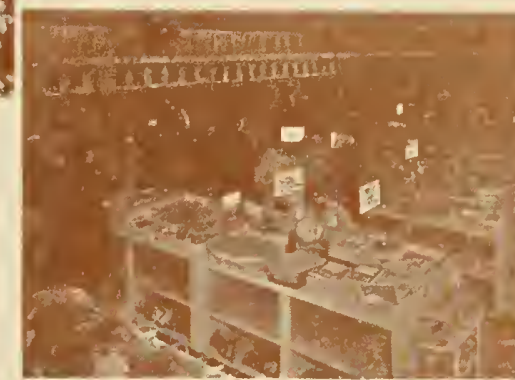

View of plant display in our
retail Salesrooms. display in our
retail Salesrooms.
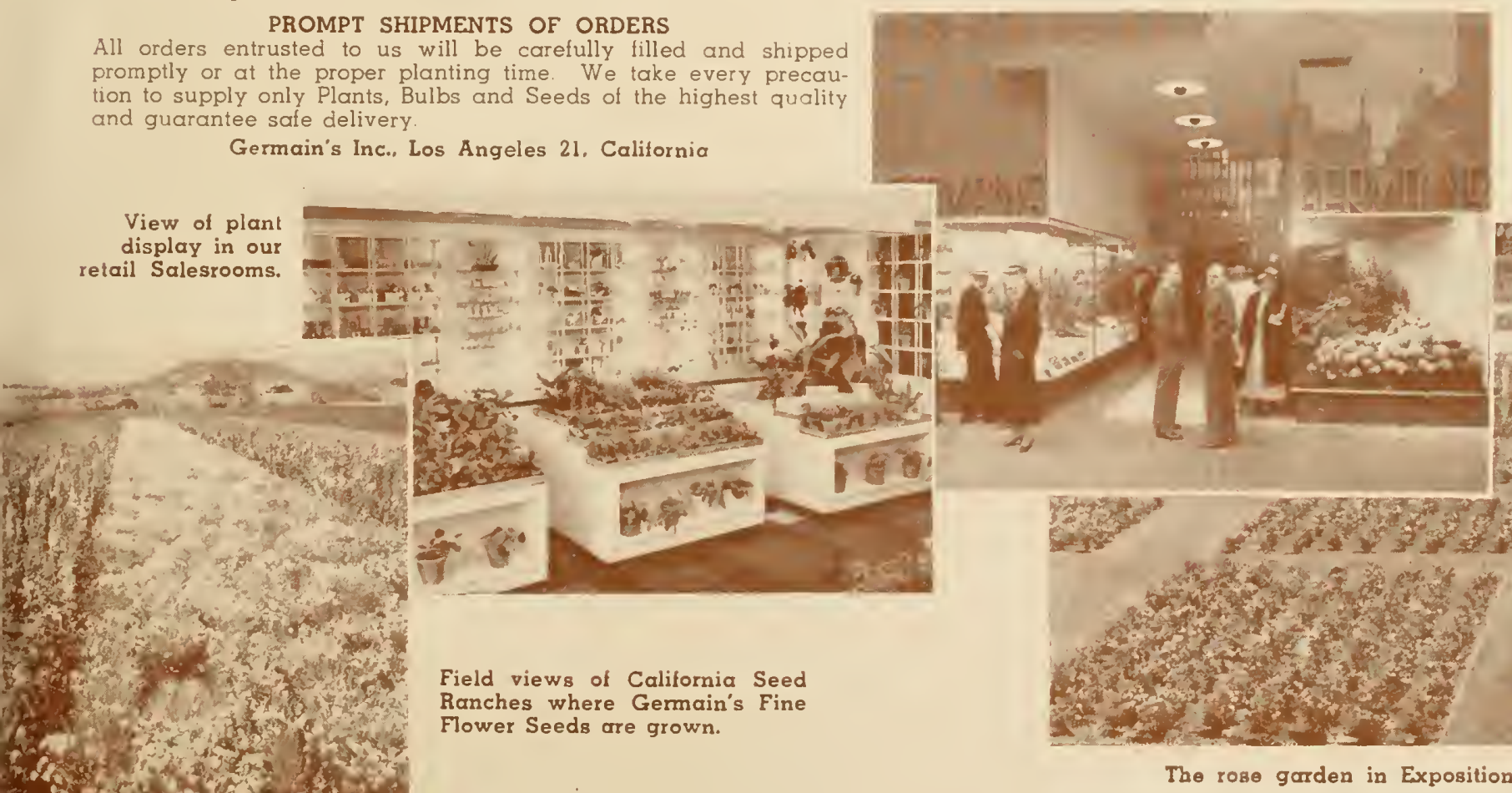

Entrance to Germain's

$I^{N}$

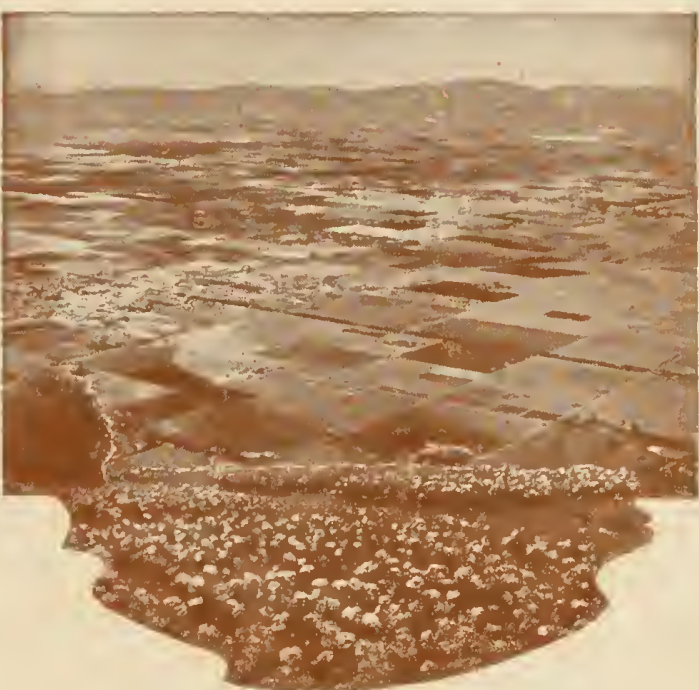

SAN FERNANDO VALLEY

N sunny San Fernando, California's "Valley of Roses", Germain's grow acres and acres of roses each year. ments almost to perfection, roses attain larger and dier growth and develop strong sun-ripened canes which give that satisfying burst of spring bloom for which Germain's patented roses are famous throughout the nation.

Ranches where Germain's Fine Flower Seeds are grown.

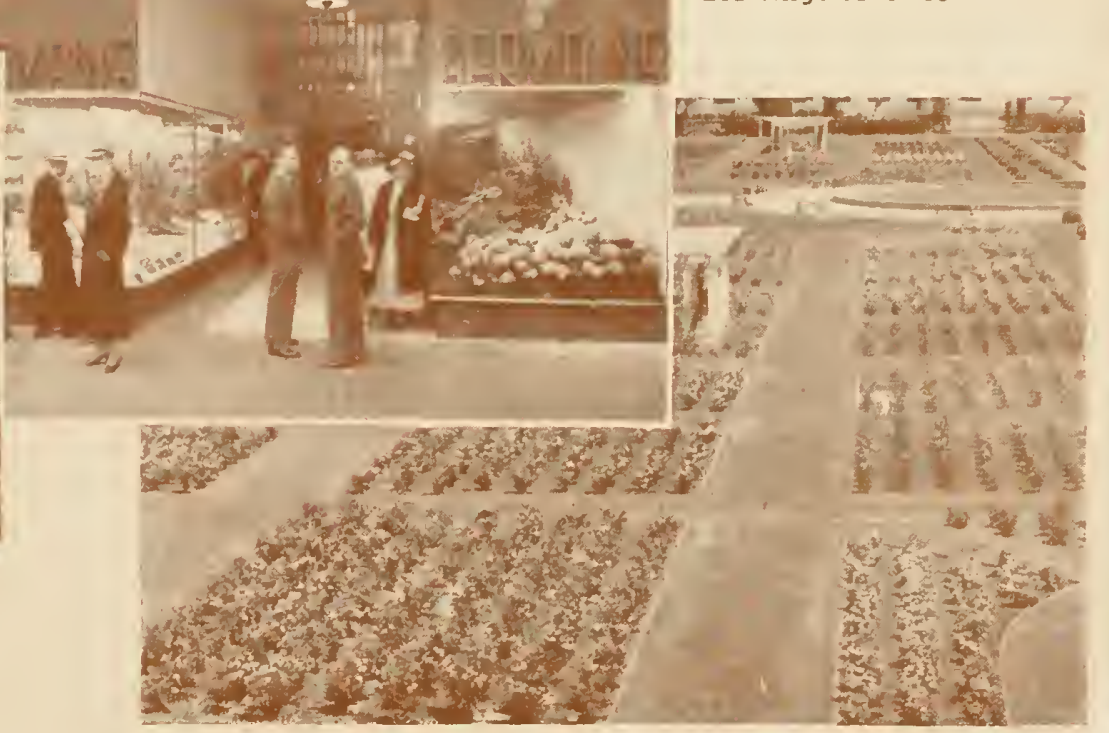

The rose garden in Exposition Park, Los Angeles 


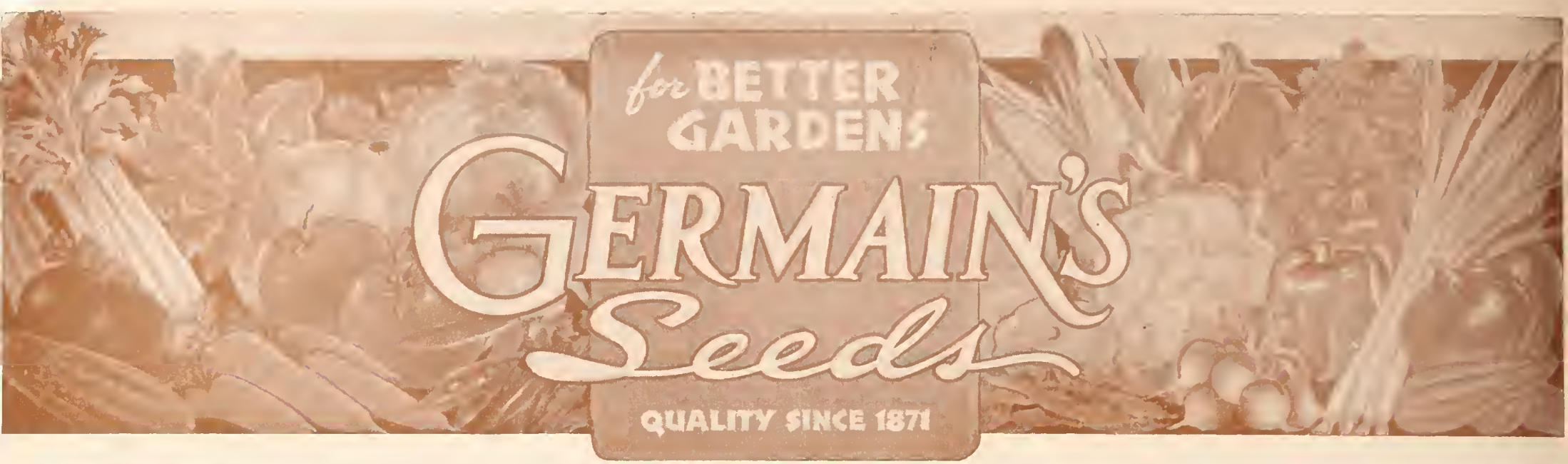

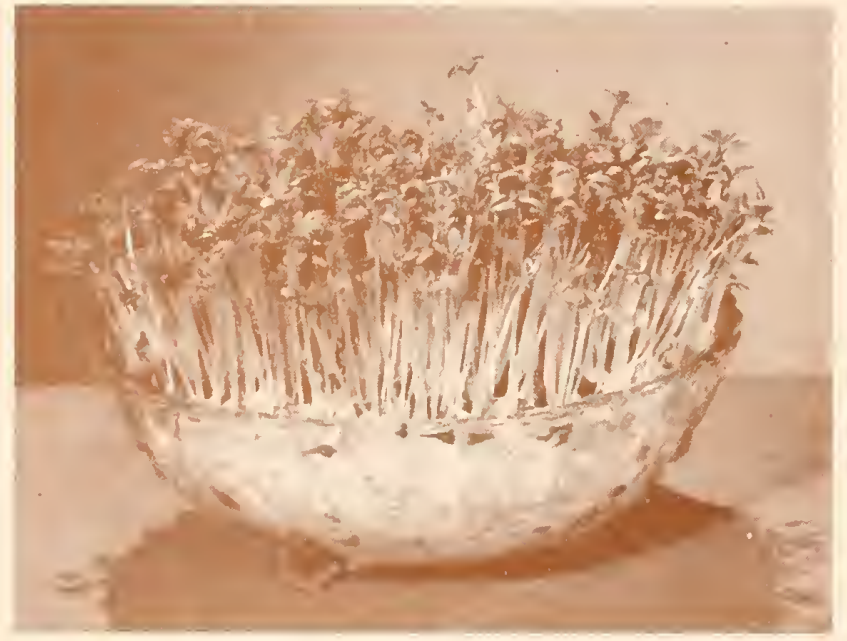

\section{AMAZING! KITCHEN GROWN} IN 7 DAYS!

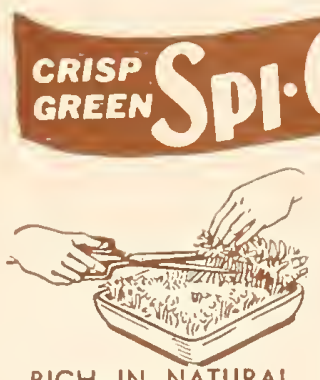

RICH IN NATURAL VITAMINS

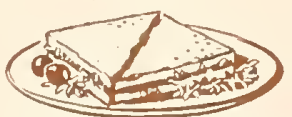

200A-INTRODUCTORY OFFER (Save 25c) 5 Big JUMBO $\$ \mathbf{\$ 1 . 0 0}$
PACKAGES (including Sponge Rok and Directions) only ...

thrills!

\section{REG PEMD}

NEW

EXCITING

taste

thrills! -grown from seed in 7 days in your kitchen! No sun needed. Adds spicy sauces, etc. Plant Seed in dish in white Sponge-Rok (included). Ready to eat in 7 days! Cut, use, then re-seed. RICH IN VITAMINS. Grown year 'round. Ornamental too - fascinating hobby! No. 200 Spi-Cee-Cress............. Pkt 25c

NON-WARRANTY. Germaln's Inc, glves no warrants, express or Implled, as to the produc

\section{GERMAIN'S SENSATIONAL NEW Seedless WATERMELON}

$\mathrm{Be}$ the first to grow and surprise your friends with this truly sensational new Dessert Watermelon-Imagine, no seeds! Germain's Seedless Watermelon, offered this year for the first time, has been hailed as a "new invention" in plant science. It is a true hybrid and, like hybrid corn, has exceptional vigor and shows marked resistance to the diseases common to melons. The finest quality fruit, is rounded in form, dark green in color and weighs about 15 to 20 pounds. The flesh is rich reddish pink, its flavor extra sweet and delicious.

In order to produce fruit, the seedless melon plants must have an ordinary melon close by to supply the necessary pollen. One ordinary melon plant to six seedless plants is sufficient.

Imagine! Fresh glorious tangy CRESS

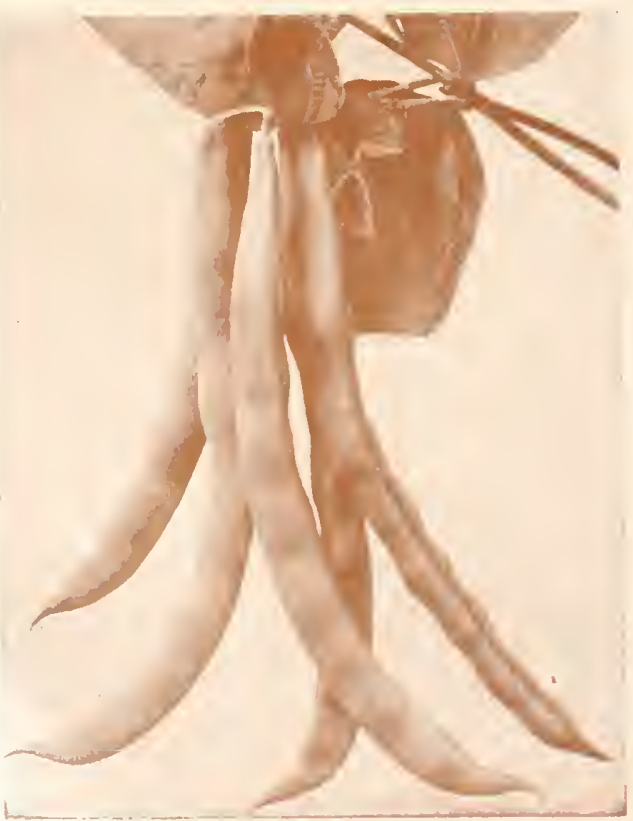

021 Landreth Stringless Green Pod ( 5 days) Used extensively by freezers, canners. market and home gardeners. Heavy producer of stringless pods, medum green $51 / 2$ inches long, very thick. meaty and $c$ excellent flavor. Seed yellowlsh brown. Pkt. 10s:

026 Black Valentine Stringless (55 days) Excellent varlety for shlpping as well as the home garden. Pods about 6 inches . A very prollitic varlety

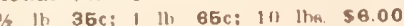

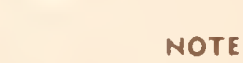

All Prices Listed

are Postpaid zest to salads, sandwiches, meats, soups,
Price per packet (10 seeds) of NEW SEEDLESS WATERMELON (Plus pkt. Klondike Blue Ribbon Watermelon)

Prices listed on Beans are postpaid. If sent otherwise deduct $10 \mathrm{c}$ per pound. Write for Quantity Prices.

\section{CULTURE}

Complete $\$ 1.00$

\section{GERMAIN'S BEANS Yield Heavily}

Plant whel ground is warm, preferably in light, rlch, well-dratned loam. Plant in drills two or in the row. If Dlanted in bllls, about two feet apart eacb way.

\section{BUSH GREEN POD}

022 Bountiful 145 anysi very inruts and produc ive. Pods likht green, $6 \frac{1 / 2}{2}$ to 7 inches lone. over $1 / 2$ in likhe yellow Pkt. Ille;

BUSH BEANS BOUNTIFUL

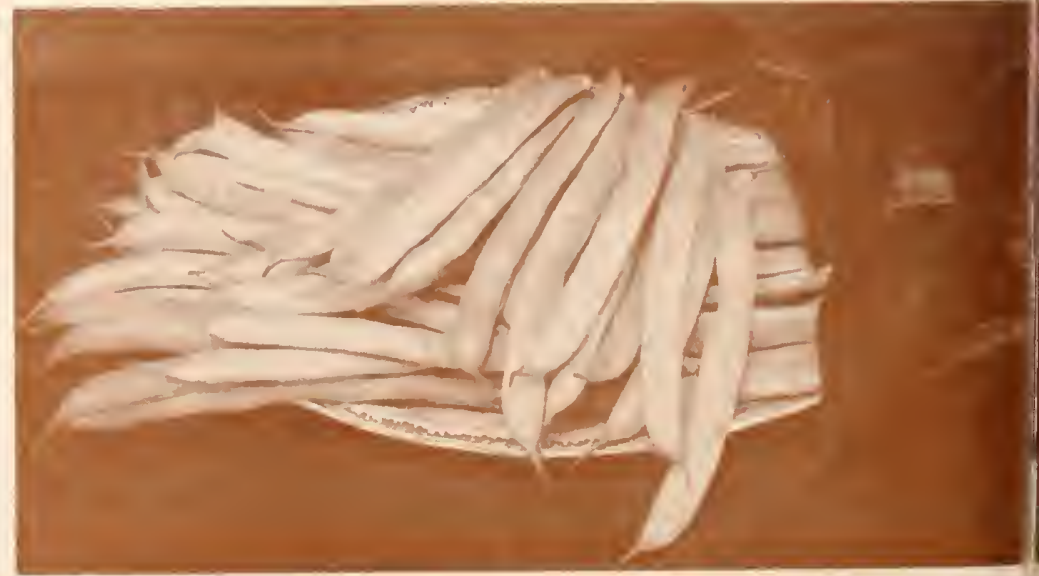




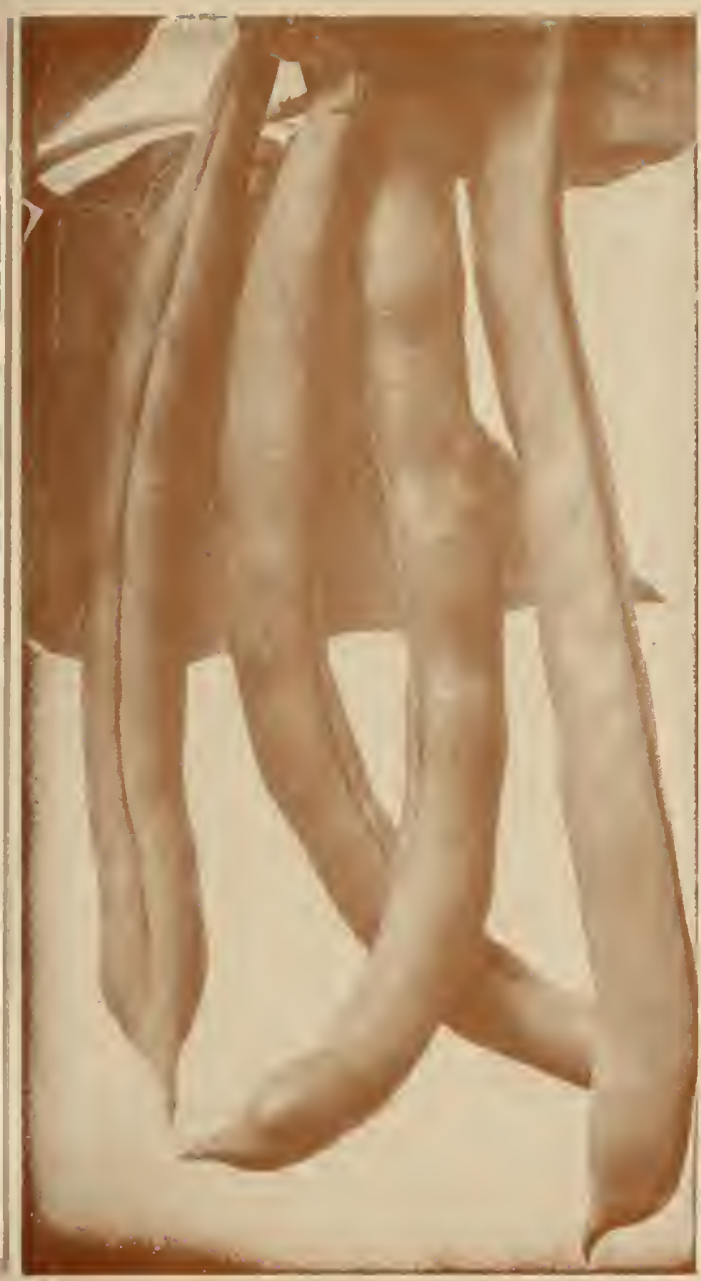

BEANS KENTUCKY WONDER

\section{Germain's Broccoli}

CULTURE-Same as Cauliflower.

106 Italian Green Sprouting Broccoli, Early Strain (75 days) An early type of broccoll having large compact central heads. with verg few laterals Pte. 16et (3) 600; 4 lb. $\$ 1.50 ; 1$ b b 84.00

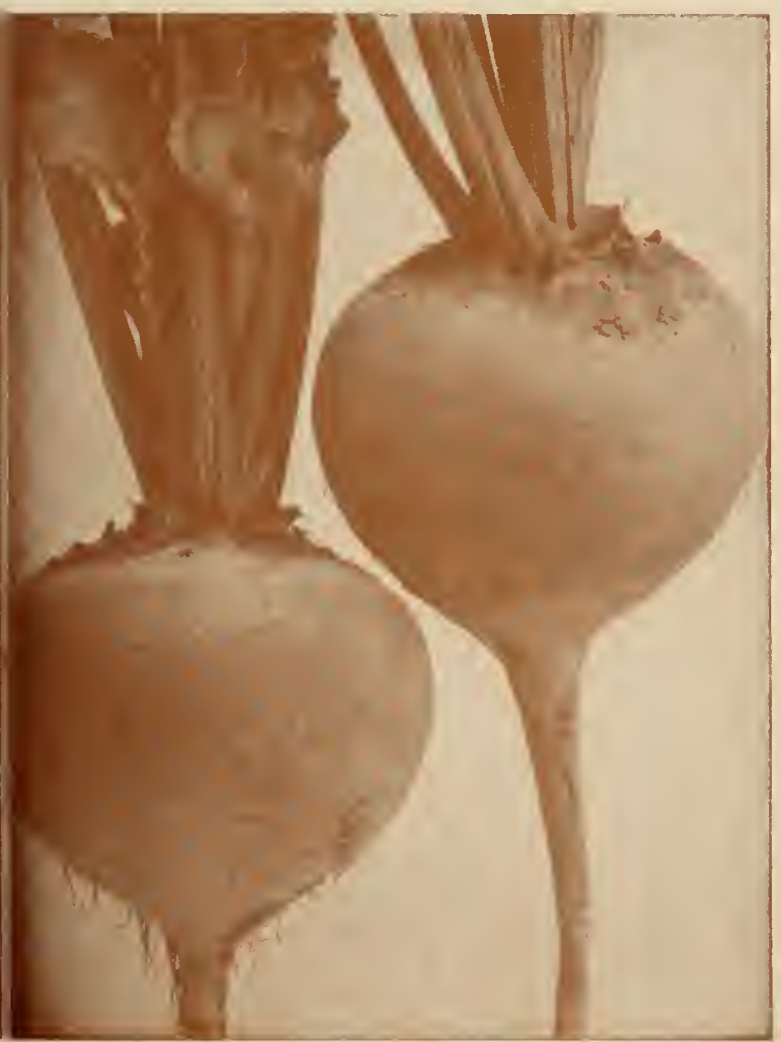

BEET DETROIT DARK RED

\section{BUSH BEANS}

\section{YELLOW OR WAX BEANS}

019 Golden Wax (48 dars) The best early wax pod. Plants medlum slze and very productlve. Pods $4 \%$ to 5 In. long. golden yellow oval and strngless. Seen

020 Pencil Pod Black Wax $(52$ days $)$ A vers superlor variety, round podded, $5 \frac{1 / 2}{2}$ to $6 \mathrm{ln}$. long. Puds golden yellnw. curved. Stringless and brttle. Tender

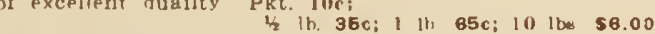

\section{POLE BEANS}

039 Kentucky Wonder Brown Seeded (65 days) This is the leading all around pole bean be. lng used allke for home gardens. market gardens and Pods very large, 8 to 10 inches, bright green round lleshy and somewhet crooked and crumpled os they mature, but leep in eating condition until fully grown Seed long, oval, of a duli brown color. Pkt. loc:

\section{Kenfucky Wonder White Seeded} No. 75 (60 days) Largely used by local market gardeners, as It has an abundance of large tender pods, 6 to $7 \mathrm{ln}$. long, and is earlier than the Brown Seeded Ken. tucky Wonder. Seeds snow white when ripe and are 045 Scarlet Runner (y0 days) Largely pianted for its brillant scarlet flowers, although it is also good as a snap bean when young. Pods dark green, 6 in. long May also be used green. shelled. Pkt. 10e; 10 the 5700

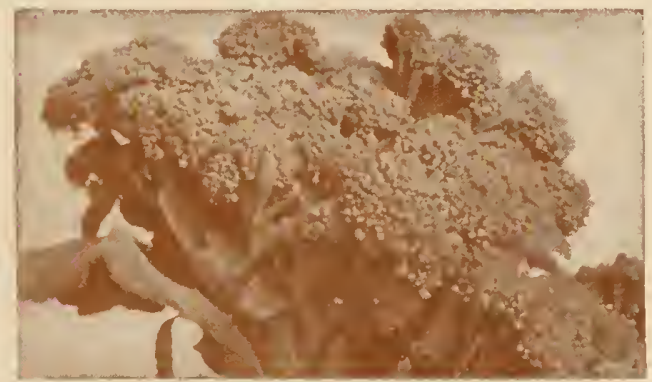

BROCCOLI GREEN SPROUTING

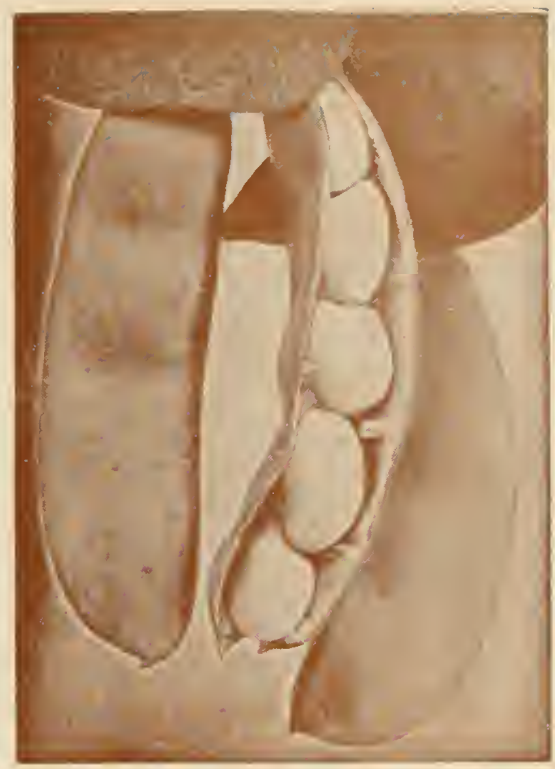

BEANS FORDHOOK BUSH LIMA

\section{LIMA BEANS CULTURE}

Llmas should be planted only in warm weather, as th seed will rot in cold soll. Except in favored warm sec tlons. We do not recommend planting before Aprll or May. Plant 2 inches deep in rows $3 \frac{1}{2}$ feet apart and $1 \frac{11 / 2}{20} 2^{1 / 2}$ feet apart In the rows, according to varlety pounds to the acre.

\section{POLE VARIETIES}

017 King of the Garden (88) days) Perhaps the most popular of the Pole Limas. Pods 6 In. long and contain 4 to 5 beans. Pkt. 10c; 5 lb. 700 : 10 lbs $\$ 6.50$

\section{BUSH VARIETIES}

012 Fordhook (75 days) The best of the Buat Limas, sometimes called Butter Bean, grows a vigorous erect bush with large pods, 4 ln. Jong, contalning 3 to larean, finest quality. Pkt. 100$\}$ ib. 40c; 1 lb. $700 ; 10$ lbs $\$ 6.80$

014 Burpee's Improved Bush Lima $\quad 170$ days) The earlest maturing of all the large seeding Limas. Pods are verg large ( $4 \frac{1}{2} \mathrm{ln}$. long), thlck and contain usualiy 4 beans of large size and excellent quality. Pkt. Jinc

\section{GERMAIN'S TABLE BEETS}

\section{CULTURE}

Thls is one of the few vegetabies that can be grown the year around. The seeds should be sown in drills 15 inches apart and $1 \frac{1 / 2}{2}$ inches deep, and covered by hand uniess following fleld culture. Thin out to 4 to 6 inches produce a successful crop. Plant $10 \mathrm{lbs}$. to the acre

080 Crosby Egyptian home garden varlety for all purposes. Tops medium wlth liahter color $\mathrm{Pkt}$ Inc:

077 Extra Early Egyptian (50 dass) A splendid varlety that matures sooner than any others. Tops small, roots smali, dark red. somewhat fiattened and
good quality. Plant for first early crop. Pkt. 10c;

2. 25c: ts tb $60 \mathrm{c}$ : 1 th $517 \mathrm{~B}$

081 Early Wonder

(60 to 65 days) Tops smali. roots very smooth, globe shaped and uniform. makln it an ideal beet for bunch she. parativels free from llght zoning. Pkt. 1lic:

082 Detroit Dark Red (55 to 60 days) Roots medium slze, nearly round and dark blood red color canning and aually sood for bome use. Pkt. I0ci Oz. 28c: to ib 60o: 1 lb $\$ 1.76$

079 Blood Turnip (60 days) A very fine struln requires a longer time to mature than Detroit Dark Red Roots are dark red, round and flesh is a deep red with lighter zoning. This variety is sweet. crisp and tender Oz 25c: \& lb 60c; I Ib. 51,7

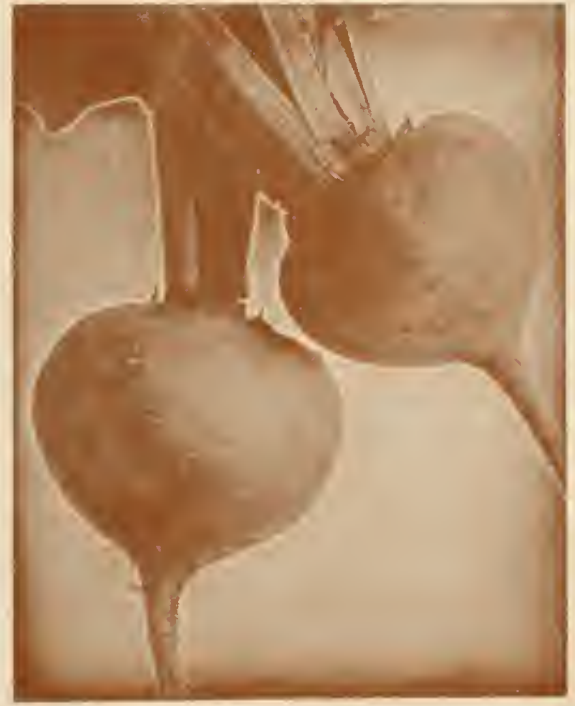

BEET CROSBY EGYPTIAN 


\section{GERMAIN'S Tender-Sweet CORN}

Prices are postpaid. Deduct $10 \mathrm{c}$ per lb. if shipped otherwise.

Culture

列 Plant in hills 18 inches apart with Three or four seeds may be planted re than two allowed to stand. removed, as they take strength from the mother plant.

221 Golden Cross Bantam (88 days) Developed by the Purdue Experiment Station. This hybrld is probably the best of all the yellow corns. Plants $61 / 2$ to
$7 \mathrm{ft}$, hlgh, ears 8 in. long. 12 to 14 rowed. Pkt. 10c; 237 Stowells Evergreen (105 days) Best for late corn. Kernels white, plants 7 to $7 \frac{1}{2} \mathrm{ft}$. tall, ears

\section{GERMAIN'S CABBAGE}

列 soon as large enough to be handled should be lifted out to their permanent place. For early varieties, such as winningstadt, plant in rows $2 \frac{1 / 2}{2}$ feet apart, plants 1 foot apart in the row. The larger headed varieties, 1112 feet apart in the row. Cabbase hay ben

122 Copenhagen Market bage ls the leader in the roundhead varieties and is the
most deslrable all-purpose cabbage we list. For earliness. heading, uniformity in size and shape and superior inches in dlameter and weigh about 4 lbs. Pkt. 10c;

117 Early Jersey Wakefield (62 days) An excellent variety. A sure header. We recommend it for the home gardener. The heads are conical in shape, 7 to
8 in. high and about 5 in. in diameter and weigh about

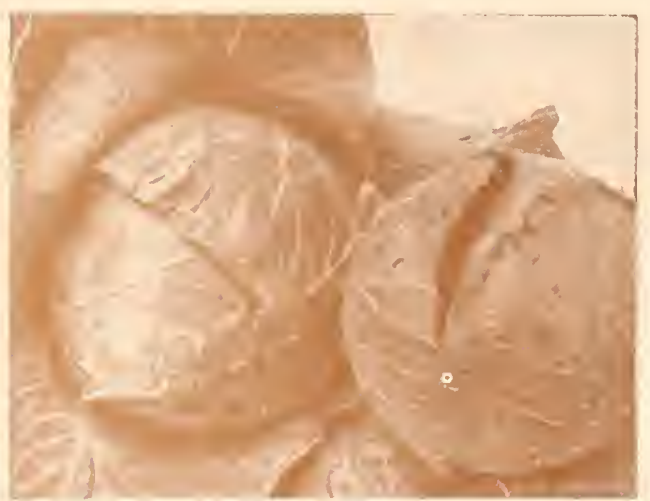

COPENHAGEN MARKET

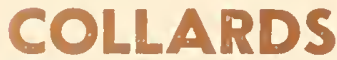

Similar to Cabbage

Culture

Georgia

\section{POT AND MEDICINAL HERBS}

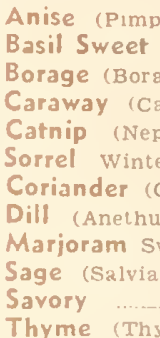

Thyme
235 Country Gentleman (95 days) A good home garden variety, cob small, grains white, very deep.

231 Golden Banfam (83 days) This golden colored corn is the leading variety for early home garden quality, very sweet and tender. Plants $4 \frac{1 / 2}{2}$ to $5 \mathrm{ft}$. tall.

236 Oregon Evergreen (100 days) Ears large and well filled to the tip with large delicious pearly crop, heavy producing variety. Pkt. 10c;

128 Late Flat Dutch and 7 in deep; bluish green, round, broad and flat on top: an excellent fall and winter variety: 27. 30c; $1 / 4$ lb. $\$ 1.00 ; 1$ lb. $\$ 3.00$

129 Drumhead Savoy (90 days). Is a heavy producer, has crumpled, deep and rich green leaves Heads are globe-shaped and large. Pkt. 10c; 1 lb. $\mathbf{\$ 3 . 5 0}$

127 Early Flat Dutch handsome, very solid, of fine quality, and as one of markets or for late spring use compact growing with excedingly hardy in resistlng cold and Pkt. 10c:

0 \%. $30 \mathrm{c} ; 1 / 4$ lh. $\$ 1.00: 1$ lb. $\$ 3.00$

134 Chinese White early variety of Chinese Cabbage. Heads are 33 to 4 and tender. Pkt. 10c: 18 inches high. Very solid. swcet

\section{CARROTS MOSt Nutritious Root Crop}

\section{Culfure}

Sow any tlme ln deep, loose soll preferably sandy loam about $1 / 2$. Inch deep, In rows 18 inches apart and thin out to 3 inchcs apart. Water freely at all times. One
ounce of seed will sow about 150 feet of row. Four pounds to the acre.

159 Imperator (77 days) 1 it is sleek, 7 to $8 \mathrm{ln}$ in length with round shoulders, allowing it to binch well. Its color is a deep orange and its core is ver indistinct. Pkt. 10)

155 Chantenay (70 days) The best of the early Carrots, about 6 in. long, stump rooted. sinooth, fille grained and sweet; a fine sort of bunching, for market
or for hoine gardens. This variety ls deep oranke ln

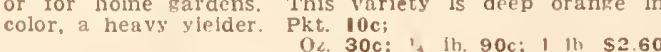

153 French Furcing (60 days) An excellent varlety for home garden and early market. It is reddish orange in color, small and globe shapcd, excellent quai-

156 Danvers Half Long (75 days) Very popitlar varlety for market garden and home garden purtapered and blunt at end. Pkt. loc;

158 Oxheart (75 days) A short thick varlety, the best to plant in hcavy soll where it can be easily lifted.
Roots are scarlet-orange in color, about 5 in. In length. Pkt. 1lic; $0 z .30 \mathrm{c} ; 1 / 4$ lb. 90c; 1 lb. $\$ 2.60$

157 Long Orange (85 days) A very heavy producer on light porous solls. It ls a large varlety 10 to
$12 \mathrm{in}$. long, $3 \mathrm{ln}$. across at the top. tapered and Dolnted. Pkt. 10k:
SWISS CHARD

091 Rhubarb Chard A dellclous vegetable, pos. sessing such beauty that it may well be used for flower borders and frequently ls seen, both leaves and stalk, in flower arrangements. It is as a tasty vegeta. translucent, crimson stalks alone may be used, or only the green leaves cooked separately, or both together in store for you. Grows to maturity in 60 days. Pkt. $15 \mathrm{c}$; 088 Swiss Chard, Large White Ribbed (60 days) Leaves smooth and dark green, stem thlck. broad and white. Grown for lts leaves, which have excellent flavor when cooked like spinach. Cut often and new stalks will be produced. 0 25c; $1 / 10$ lb. 50c; 1 lb. $\$ 1.50$ 08? Swiss Chard Lucullus (60 days) Leaves very crlnkled, of an attractive dark green color and very thick and fleshy. Easily grown and furnishes a
supply of good greens for a long period. very desirable for poultry feed. Pkt. 10c; $25 \mathrm{c}$, 4 lb 50c: 1 lb. $\$ 1.50$

\section{GERMAIN'S CELERY}

\section{Culture}

Sow from February to May in drills 1 foot apart. Later usually in June, transplant to rows 3 feet apart and 6 inches apart in row. Rows should be furrowed out so plants may be set 6 hows sheep. Lever, soll olled selfblanchlng varieties needing the cool molst soll to render the staks crisp and tender, but this should not be done until a few weeks before harvesting. One ounce of seed will produce 5000 plants.

195 Golden Self-Blanching Dwarf (90 days) Plants 20 to $24 \mathrm{ln}$. tall. stalks thick and solid and auality. Pkt. 15c

$$
\text { 07. } \$ 1.00 ; \text { id lb. } \$ 3.25
$$

196 Pascal (120 days from seed) An excellent green varlety of nutty flavor. Plants large. Stocky, with
dark green leaves, blanching to a yellow white. Pkt. 15e;
$07 . \$ 1.00 ; \%$ Ib. $\$ 325$

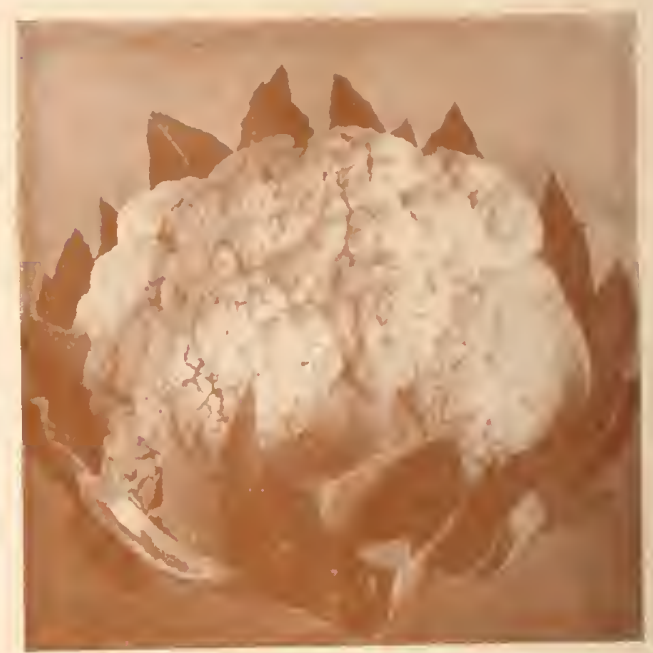

CAULIFLOWER MEDIUM PEARL

\section{CAULIFLOWER}

\section{Culture}

Prepare the seed-bed carefully, using only rich and thoroughly pulvcrlzed soll. Good results are obtalned condition. Broadcast the seed in the seed-bed prepared. sowing the eariy varleties from May 15 th to June 1 st. medium early varictles May 20 th to July 5th: and late varietles any time from June 25 th to Aug. 25th, inclusive. When 40 days old transplant to the ficld. 24 in. apart In rows 30 to 36 inches apart. Do not leave plants and poor results follow.

182 Medium Pearl (January-February maturity) Plant secd-bed between June 15 th and July $25 \mathrm{th}$. We have developed an exclusive straln of this type of caull. flower sced that has met with great favor amons exceptional quallty. Pkt. 15c;

\section{CHIVES}

\section{Grow Like Green Onions}

211 Chives The same methods of growing are used as for green onlons. When the plant is about 2 ln, high whlch are 12 in. apart. It is a perennlal of continuous growth and as the leaves are cut away, new growth comes on Plt 150 


\section{GERMAIN'S CUCUMBERS}

\section{Culture}

Cucumbers should not be planted until all danger of frost is over and the ground is warm. Sow 6 to 10 seeds in hills 4 to 6 feet apart sone and soil seed should be planted 1 inch deep. One ounce will plant 50 hills; 2 pounds, 1 acre.

274 Klondike (64 days) Another good whlte spined variety, medium length, very dark color and fine quality. lbs $7 \%$ in. lon and

lbs., $71 / 2$ in. lo. 25c; $1 / / 4$ lb. 85c; 1 b. $\$ 2.50$

268 Boston Pickling (60 days) An early pickling or slicing variety. Frults welgh about 11/2 lbs., 6 in.

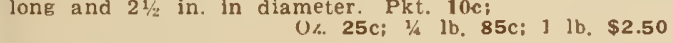

279 Improved Long Green (70 days) one of the best for all purposes-fruits long and slender, in. long and $2 \frac{1}{2}$ in. In diameter. Pkt. 10c:

Oz. 25c; $3 / 6$ lb. $85 \mathrm{c} ; 1$ lb. $\$ 2.50$

267 Lemon (65 days) This cucumber is the slze and shape of a good sized lemon, color creamy white When at its best eating condition, which turns yellow when very crisp and delicate and never turning bitter. Pkt. 10c;

02. 30c; $1 / 4$ lb. $\$ 1,00 ; 1$ lb, $\$ 3.00$

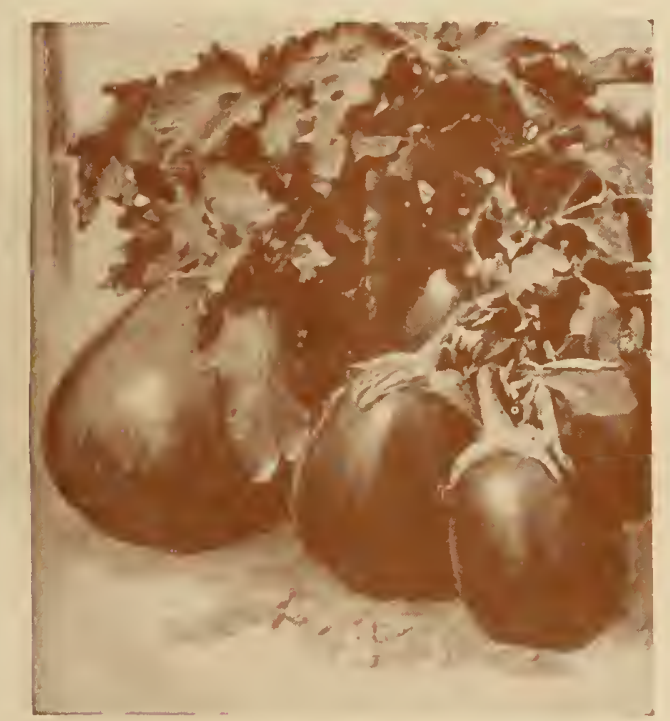

EGG PLANT NEW YORK

\section{EGG PLANT}

\section{Culture}

The plants should be started under glass if wanted early. If later results are desired, seed should be planted in cold frames or in boxes where special care can be given. taken to have the soil in beds or boxes moist. Plants should not be set out permanently until all danger of frost is over, using plants 6 to 8 inches tall of vigorous growth for setting in the field. Space plants 3 feet apart each way.

308 New York Improved (83 days) An ear!y variety, large, oval-shaped and the deep purple kind that tastes surprisingly like oysters when fried. This variety is a great producer 50 to 60 pounds having been
grown from one plant. Pkt. 15c; grown from one plant. Pkt. 1;ic;

\section{ENDIVE}

Culfure same as for letiuce

317 Green Curled (95 days) Makes a fine salad especially for winter use. When ready for use outer leaves are green wi:h the center of the head blanched Oz. 25c; $1 / 4$ lb. 70c; 1 lb. $\$ 2.00$

316 Broadleaved Batavian (90 days) Makes an excellent winter salad. Grown like lettuce and heads tied loosely for blanching. Regarded by some as the best
of the Endives. Pkt. 15c;

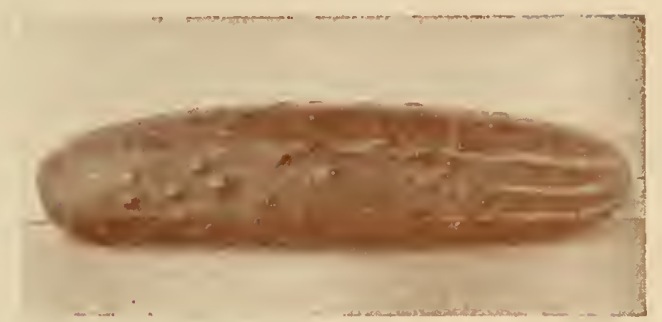

CUCUMBER EARLY FORTUNE

275 Early Fortune (66 days) one of the bes cucumbers for home or market grower. It is about 9 in long, of uniform diameter ( $\left.2 \frac{1 / 2}{\mathrm{in} .}\right)$, making it an ideal shape to pack and carry nicely. The color is a deep atvery crisp and solid. Pkt. 10c;

273 Davis Perfect (68 days) A favorite with market gardeners and shippers. Long, slim and dark about 2 lbs 10 in, long and $21 / 2$ in. in diameter. Pkt. 10e;

Oz. $25 \mathrm{c} ; 1 / 4$ lb. $85 \mathrm{c} ; 1$ lb. $\$ 2.50$

\section{KALE or BORECOLE}

\section{Culture}

Plants are usually cut off when the leaves are 6 inche or more in length, but with the fine curled varieties th leaves can be gathered for use when of good size. If leaves should be carefully pulled of so that the plants can grow on and furnish a continuous supply. One can grow on and furnish a continuous supply. One an acre. Seed should be sown thinly in drills and planis reset 18 inches apart in rows 3 fcet apart.

322 Dwarf Curled (85 days) very hardy, excellent for spring use. This variety grows 12 to 15 in. tall
and $30 \mathrm{in.}$ across. The leaves are finely curled and are Oz. 25c; $1 / 6$ lb. 85c; 1 lb. $\$ 2.50$

324 Thousand Headed or Jersey (80 days) An excellent food for poultry, an immense yielder. Crops are known to have gone as high as green feed per acre. Anyone having poultry should and the plants transplanted when from 6 to 8 in. high. The plants should be set 3 feet apart each way. They grow about $4 \mathrm{ft}$. high with a wide spread of leaves an a single plant often weighs 30 to 40 lbs. Pkt. 10e;

\section{KOHLRABI}

\section{Culfure}

A haldy plant and seed may be sown practlcally all the year around. Plant lt like turnlp and thin to 6 inches Use when $2 \frac{1}{2}$ to 3 in. in diameter as it soon becomes woody.

328 White Vienna (55 to 60 days) Flesh, white and tender. Pkt. 10c; (1). 25c; 1/ 1b. 85c; 1 lb. $\$ 2.50$

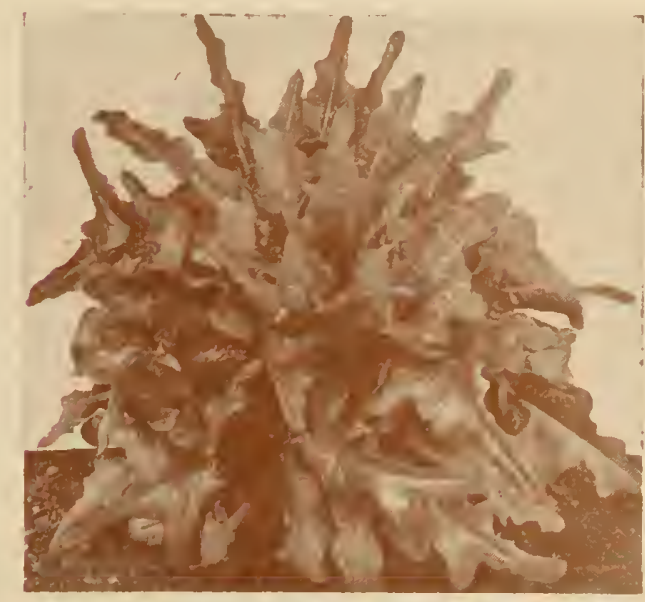

LETTUCE BRONZE BEAUTY

\section{LETTUCE}

\section{Tender, Crisp and Sweet}

Culture for the home garden. Loose quickly than heading

for 150 foot

when fourth leaf appear

lettuce. Crop needs ample

vation. In field plantin

plant on ridges

irrigation between the ridges.

Write for Quantity Prices

350 Black Seeded Simpson Pkt. 110c:

351 Early Curled Simpson varieties of the loose leaved kind
crisp. and tine flavor. Pkt. 10c;

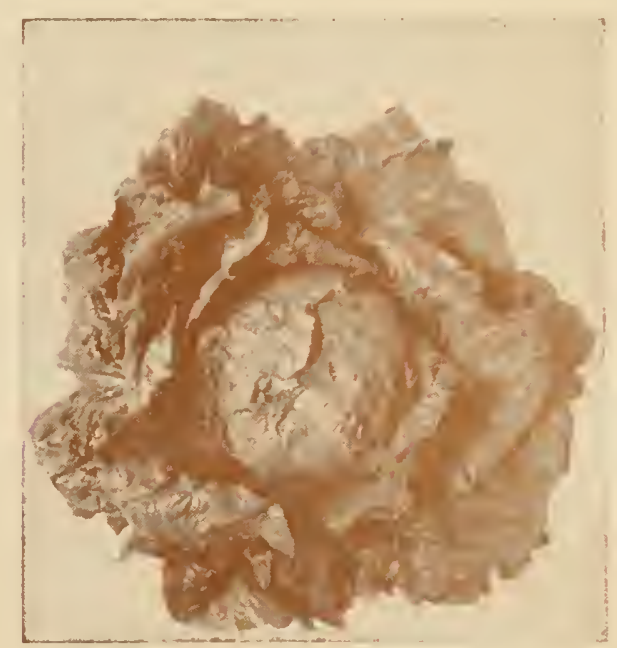

LETTUCE NEW YORK NO. 12

345 Iceberg

ing a solid lith

but not as is very large.

\section{Big Boston}

attractive green color

\section{Prizehead}

gardens because

inner leaves are
tender. Pkt. 10c

344 New York No, 12 an mpoved tope?

and sure heading. Is of fine appearance, excellent qual-

$15 \mathrm{i} ; \mathrm{i}$
$15 \mathrm{a}$

\section{Bronze Beauty Lettuce}

(All-American Selection)

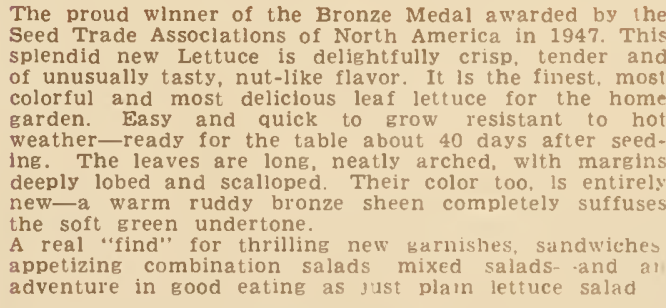

368 Bronze Beauty Pkt. 10c; $\$$

\section{ROMAINE or COS}

355 Paris Green Cos Plant upright and long, 8 to 10 inches. dark green. Sclf blanching the heart is greenish white, very tender and sweet
Pkt. Inc; 


\section{WATERMELONS}

\section{Finest, Sweetest Flavor}

\section{CULTURE}

Mrrows or abed and 6 to 8 seeds ure planted about row in the furrow. plll in the soll about them so as to establlsh ronts well into decper ond when the plants are securely established plick out all hut (wo of the most plant only atler eround is warm and provtde ample molsture

438 Angeleno Black Seeded large, about 20 lbs. A round melon with a strong rind of dark green color. flesh brisht scarlet and of good

444 Kleckley Sweet (85 days) A medlum slze melon, rind thin dark green, flesh deep red, dellclous lavor. An excellent melon

Oz. 25c; $1 / 4$ lb. $70 c$; 1 lb. $\$ 2.00$

447 Tom Watson (95 days) A very large melon welghing 35 to 40 pounds, an excellent shlpper. Skin deliclously sweet and julcy. Pkt. 10c; Oz. 25c: $1 / 4$ lb. 70c; 1 lb. $\$ 2.00$
446 Striped Klondike Klondlke but size and shape stripes on the outer rind. Pkt. 10c; $1 / 25 \mathrm{ll}$. $85 \mathrm{c} ; 1$ lb. $\$ 2.50$ 439 Chilean Dark Seeded early watermelon for the family supply or shipping to market. Is medium size, outer color light and dark green can be eaten rlght down to the rind. Is very sweet Welght about $10 \mathrm{lbs}$. Pkt $10 \mathrm{c}$

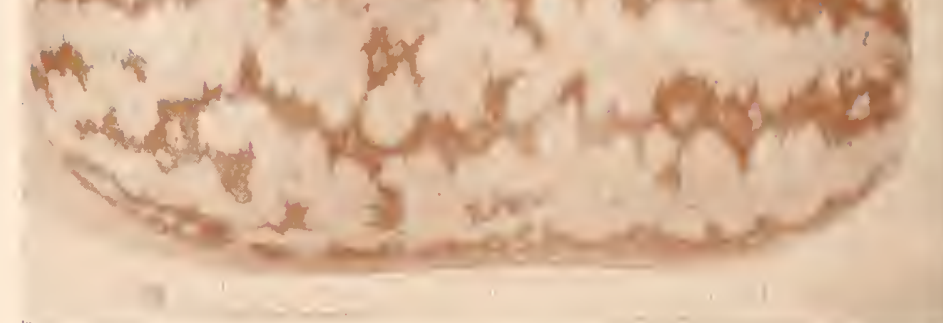

WATERMELON STRIPED KLONDIKE

445 Klondike (85 days) A dark seeded meloo which, with its bright red llesh. Elves it a very attractive appearance when cut. The sweetest, finest flavored

\section{MUSTARD}

\section{Culture}

Sow ang time in the year, though autumn sowing brins best greens, for mustard likes cool weather. No best. Seeds should be planted in rows elghteen inches apart and plants thinned to 6 Inches apart.

466 Southern Curled Leaves large light green. inely curled, and have a mild agreeable flavor. It also makes a fine areens for poultry. Pkt. 100 :

\section{O K R A \\ Culture} seeds to the hill, and when plants are thoroughly establlshed, pull out all but
three. Cover seed at depth of one Inch and as plant grows gradually flll up the furrow. Plant $12 / 2$ pounds of seed to the acre.

401 Hales Best thes of the original type, but being larger in size. For this reason it is increasing in popularity in many sectlons. Pkt. 10e

$25 \mathrm{c}: 1 / 4$ tb. $850: 1$ lb. 52.50

392 Tip Top (86 days) An oval melon about 7 or 8 inches lone. The flesh is deep yellow, very thick and Oz. 25c: 1/4 1b. $85 \mathrm{c} ; 1$ lb. $\$ 2.50$

400 Burrells Gem (100 days) A salmon fleshed melon of flne quallty and a little larger than most others. A fine home garden melon. Has a very smat $\begin{array}{lll}\text { lone. Pkt. 1nc; } & 0 z \text {. 25c; } 1 / 4 \text { lb. } 85 c ; 1 \text { lb. } \$ 2.60\end{array}$

411 Persian (Medium) (115 days) A small type Persian Melon. Is unlform in size. Frult is about $81 x$ to elght Inches in dlameter and can be packed in type. Pkt. inc;

388 Cranshaw (110 days) If you really enjoy a cood, mouth-watering melon-plant Cranshaw! It's a
cross between the flavorable Perslan and the meaty Casaba. Dlstingulshed by Its smooth skin, golden in color, its flrm. salmon colored flesh, flne aroma and rlch Ilavor. Becoming an important shipplng varlety. Itor:

\section{ONIONS}

Culfure

Osually planted in Calliornla in September for spring nlons and November to March for later crops. Sow using on this basls 3 pounds of seed per acre. The plants must have a steady even growth as a check go to seed. When the onlons are ready for harvesting

495 Australian Brown

A large brown onlon for belng a good keeper and long distance shipper as

the outer skln $1 \mathrm{~s}$ heavy and does not break and peel

18 Yellow Globe Danvers A well known early onlon of flne quallty. Flesh whlte and firm. Color abrlaht straw, grows to a good size, hardy. a sure
croner and a good keeper. Pkt. 15c:

504 White Portugal or Silver Skin one of leadlng white sorts, of beautiful shape and very flavor. The bulbs are flat and mature early
dld varlety for market garden. Bulbs averaze two inches in diameter. Pkt. 15c: $\$ 135$. 1 $\$ 4.00$

\section{Honey Dew}

412 Honey Dew (115 days) A medium stze oval melon of a dull creams white color, flesh green, quit and 6 inches in diameter. The rind is tough, wlthout nettlng. Ships well to distant markets. Pkt. 10c:

413 Honey Dew Gold Rind (105 days) Frult slmilar in every way to regular Hones Dew except at
maturity has a deep golden colored rind. Develops maturlty has a deep golden colored rind. Develops about 10 dass earlier than regular strains. Pkt. 10c;

\section{Casabas}

415 Golden Beauty (120 days) Thls superior variety is rightly named; is a true golden color and skin is tough, allowing long distance shipping. In shape almost a elobe, 6 to 8 inches in diameter, with wrinkles very thick julcy and sweet can be kept for weeks after plcking. Pkt. 10c;

419 Improved Hybrid (105 days) A I a r e e melon, very proliflc; it can be planted early or late: has a dellclous flavor. Pkt. 10c; 260 ; 1/4 850 : 1 in $\$ 2.50$

505 Southport White Globe A tavorlte white

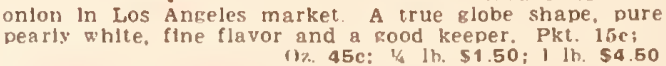

498 Red Italian (Torpedo Shaped) An exceedIngly good onlon for market or home. Very popular in Northern Callfornla. Pkt. 15c:

521 Utah Sweet Spanish Thls is a comnaraIIvely new type belng a selectlon of the Riverslde Sweet Spanish that has a thlcker skln. a hlgher and thinner
neck. Is a better keeper. has a darker brown color. and heck. Is a better keeper. has a darker brown color. all ness and size that are lound In the Rlverside Swent
Spanlsh. Pkt lis:

497 Large Red Wethersfield One of the leading varletles for mans years. In color the skln is a deep purplish red. The flesh is white, tinsed with red
Of good quallty. crisp and solld. It grows to a larke Of good quallty. crisp and solld. It grows to a lark
slze and is both a good keeper and shlpper. Pkt. 15 r: (1). $400^{2}: 2 /$ ll $\$ 1.35: 1$ ll $\$ 4.00$
Seed can be planted from the middle of March untय the latter part of August. Plant 18 lnches apart in rows 3 leet apart. Plant seed $1 \frac{1 / 2}{1}$ inches deep. One ounce of seed will sow 50 feet of row. The vecetable used in soups and stews.

476 Long Green (68 days) Later and more productlve; rlbbed pods. The pods are deep green and ?
to 8 inches long and plants grow to a helght of $11 \mathrm{ve}$ to six feet. Ptt. 10c; 477 White Velvet (70 days) Pods 6 to 7 inches long. round, smooth. White in color, free from seams. exceedingly tender, well flavored and very prollilc and cannlne because of lts smooth pods. Pkt. 100i 75

\section{LEEK}

\section{Culture}

Leek is a very hardy plant with a sweet onlon-1ike flavor. Plant seed in seed-bed, broadcast or in drille. covered to depth of one-hall inch, and when plants are be transplanted in rows 24 in. apart, and plants 6 in

335 American Flag 0z. 50c; $\%$ lb. $\$ 1.70 ; 1$ lb. $\$ 5.00$

\section{Onions Bunching}

510 Bunching Onion Produces the long. tender and sweet green onlons Qhich are justly $s c$ popular on the table good eating. It can be easlly grown in very garden. Pull while medlum size formed. Pkt. 150 c; $1 / 4$ in. $\$ 1.70$

511 Evergreen White Bunching Is bulbless, perennial and forms long, slen. der. leaf-like sllvery for bunching. The onlons produce clusters of four to nine and are twice bunching on $10 \mathrm{~ns}$. Pkt. 150 : $\$ 1.70$
$\$ 500$ 


\section{PARSLEY CULTURE}

Same as for Lettuce. See page 20

535 Moss-Curled Vigorous, compact-growing va. rlety; excellent for garnishing and flavoring. also a handsome decorative plant. Leaves fine and crisp. resembling moss. A most popular sort for the market and home garden. Pkt. 16c; Oz. 25c; $3 / 4$ lb. 600; 1 lit. $\$ 1.50$ 534 Hamburg or Turnip-Rooted The roots

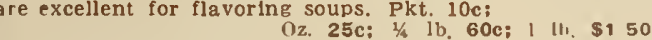
533 Plain Parsley Leaves flat, deeply cut but not curled very dark green in color and very hardy PKi lile: $\quad$ (1) 25c; $1 / 4$ tb. 60c; 111 . $\$ 150$

\section{PARSNIPS CULTURE}

Sow any month in the year in drills in rich soll $1 / 2$ inch deep and 30 inches apart, and cultivate the same as carrots; thin to 4 inches apart. One ounce of seed wll sow about 100 feet of row.

540 Hollow Crown (130 days) o u r Hollow Crown is an excellent parsnlp, produclng very fine, long, smooth, pure white roots of fine quality. Roots are 12 Oz. 25c; $1 / 6$ lb. 60c; 1 lb. $\$ 1.50$

\section{GERMAIN'S PEPPERS CULTURE}

For early market peppers, seed should be planted In hotplants are of proper size and the danger and, when the they should be planted in the open fleld or garden or he plants may be planted direct in the open ground before the frost period is over if they are glven proper protection. Six ounces of seed will plant 1 acre.

573 California Wonder

(122 days) The best large frulted pepper, very smooth. Meat thlck, tender Peppers are about 5 inches in length and $4 \mathrm{in}$. in widtl. belng blocky in shape. Rlch and glossy green. Pkt. 15c: 574 Bell or Bull Nose (118 days) The earllest of the sweet bell shaped peppers, medium slze, long a Oz. 70c; $1 / 4$ lb. $\$ 2.50 ; 1$ lb. $\$ 7.00$ 588 Floral Gem (118 days) The favorite small hot pepper for plckling and hlghly flavored sauces.
Cone shaped. 2 ln. long, green to creamy white and \begin{tabular}{l} 
Oz. 85c; 1//4lib. \$2.90; 1 lb. $\$ 8.60$ \\
\hline
\end{tabular} 581 Anaheim Chili (128 days) A leading vartety among the hot or pungent peppers; used both as green

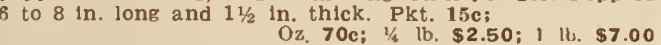
582 Mexican Chili (132 days) The kind used in making tamales and pungent sauces. Used almost exer. Peppers 5 in long 2 in thlck tapering to a point Pkt. $15 \mathrm{c}$;

577 Ruby King 9 (118 days) A large pepper, about 5 in long and $2 \frac{1}{2}$ in. thlck, slightly tapered. Deep green
in color, turning to a bright red and very sweet and mild. Excellent for stuffing or salads. Pkt. 15c; 571 Perfection Pimiento (125 days) The best of the medlum slzed smooth sweet peppers, largely used by canners, and excellent for stuffing. Peppers smooth.

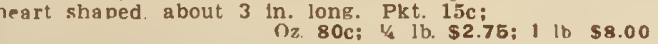
SPINACH PRICKLY WINTER

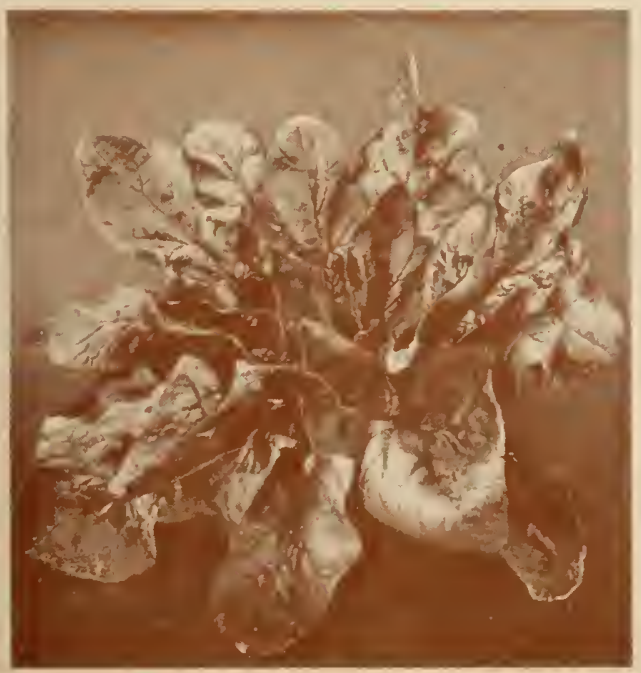

\section{GARDEN PEAS}

\section{CULTURE}

Peas may be planted in almost any kind of sull. in alm months theyld be planted about 3 inches deep so as to be near molsture. In heavier solls or in fall months plant about 1 Inch he seed. Rows should be about $21 / 2$ to 3 feet apart. Excessive molsture will rot the seed, so do not Irrigate after seed is planted untll the plants are well out of the ground. Usual planting is at rate of 60 pounds per

\section{EARLY VARIETIES}

549 Hundredfold (60 days) Grows 18 to 20 in hlsh, dark green foliage, pods $4 \mathrm{ln}$. long, dark green. straight, well filled. Whether you plant a few rows in of the best Pkt. life:

564 Progress No. 9 (60 days) An Improved selectlon of Laxton's Progress. Sllghtly larger of pod.
more thrifty of vine. Resistant to Fusarium wilt. An excellent large podded, early dwarf variety. Pkt. Ioc:

\section{MID-SEASON VARIETIES}

553 Dwarf Telephone (74 days) The best of the large podded second early sorts grows $2 \mathrm{ft}$. hleh ods large. 5 in. long and well fllled. Pkt. 10e; $\$ 4.00$

\section{LATE VARIETIES}

558 Alderman (Tall Telephone)

(74 daya) 5 fe most deliclous. Pkt. lac: dark green, peas large and

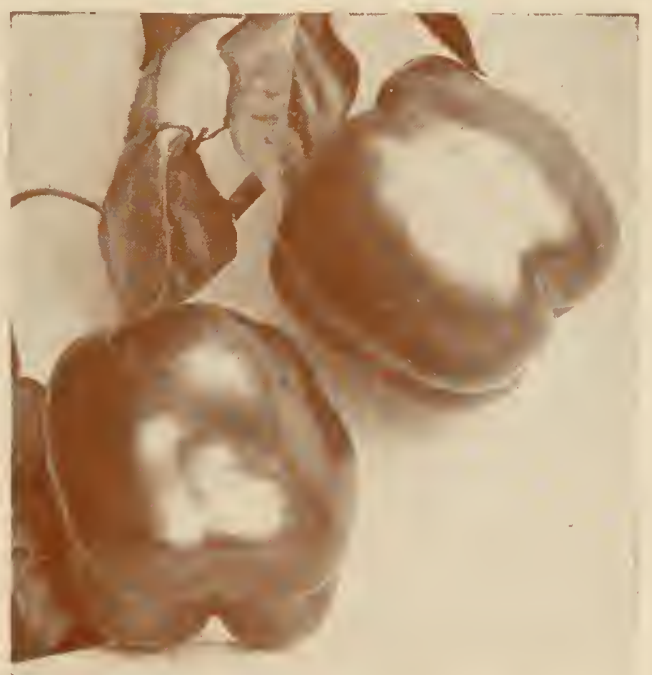

PEPPER CALIFORNIA WONDER

\section{SPINACH}

\section{CULTURE}

An all-year crop. Sow early in spring. In drills 1 foo apart, and thln the plants as you need them for cool. ing. For winter and spring use, sow in September. Onee ounce of seed will sow about 75 feet of row. In fleld plantings, 12 to 15 pounds of seed are planted per acre and plenty of water.

658 Bloomsdale or Savoy-Leaved Spinach ( 40 days) A favorite with market gardeners It has thick. dark green wrinkled leaves and is very hardy. The earliast varlety and one of the best fn

662 Viroflay 143 duys) Smooth seeded varlety used by both canners and market growers. Leaves large. .

659 Prickly Winter (45 days) The leading rarlety in our splnach list. The plant is vigorous, leare large, thick and of finest quality. Plants are very slo

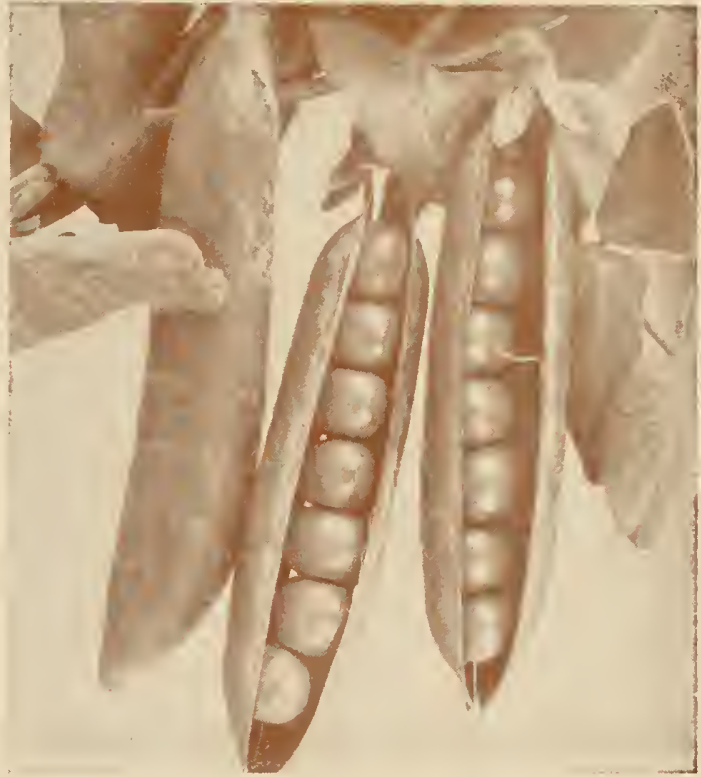

PEAS PROGRESS NO. 9

Plant PEPPERS and PUMPKINS 3 Weeks Earlier with HOTKAPS See Page 31

Prices are Postpaid

Deduct $10 \mathrm{c}$ per $\mathrm{lb}$. if shipped otherwise.

\section{GERMAIN'S PUMPKINS}

\section{CULTURE}

Pumpkins grow and th hills 8 to 10 feet apart each way, placlng 4 seeds to a hill and after established, pull out all but 609 Boston Pie or Small Sugar A very popular small variety. The skin is deep orang yellow and the flesh sweet and fine gralned. Fruts
flattened 6 in. hlah and 8 in. in diameter. Pkt. 10c; 610 Large Cheese or Kentucky Field inarket usendid keeper and a fine sort for far also. Frults 12 to 15 ine makes lt desirable 10 stock Californla. Pkt. 1110; $\quad 02$ 25ct th $65 \mathrm{c}$ : 1 lb. $\$ 2.00$

\section{Cushaw Green Striped}

large crook-necked pumpkin is excellent in warm loca and is used largely by 614 Mammoth King (83 days) Forms Immense globular frults. flattened a llttle at the end. Skin reddish yellow in color and flesh bright yellow. This is unquestionably the very best mammoth pumpkin we have
It runs very uniform in shape and color. and is 20 in It runs very uniform in shape and color. and is 20 in

\section{Rutabaga $\mathfrak{T}_{\text {Turnip }}^{\text {Swedish }}$}

\section{CULTURE}

784 Yellow Purple Top (100 days) The old popular standard sort both for stock feeding and table laree sipe, fine guality and an excellent keeper. Pkt. joc:

\section{Salsify CULTURE}

Sow in early spring, 1 inch deep. In drills 1 foot apar and thin young plants to 3 or 4 lnches in the row
The soll should be deep and loose, and never allowed to get dry General care same as for parsnips and car-
rots. Plant 1 ounce to 100 -foot tow or 6 pounds to the 652 Sandwich Island Salsify The largest an most deliclous salsify in cultivation, with long, white 


\section{GERMAIN'S Tender, Crisp RADISH \\ NOTE-Prices listed are postpaid.}

\section{Culture}

Sow any month of the year; will succeed in any good garden soli not over-moist or too heavy. For early and For those sown in summer, a rather shady spot must be selected. The seed is generally sown thinly broadcast ounce of seed will sow about 100 feet of drili. or a bed

\section{Scarlet Turnip White Tip} leading home garden and market radish. By succesve plantings you can keep your table supplied the year lound. Is round, of medium size, bright red in color Oz. 25c; $1 / 4$ lu. 50c; 1 lb. $\$ 1.50$ 623 Scarlet Turnip (25 days) scarlet in color turnip shaped, very crisp and of excelient flavor. One
of the best varieties for the home gardener. Pkt. 10e: 635 Early long $02.25 \mathrm{c} ;{ }^{2 / 3} 1 \mathrm{~h} .50 \mathrm{c} ; 1 \mathrm{lb}$. \$1.50 635 Early Long Scarlet S. T. (29 d a y s) A standard home and market garden variety of the long
type. Tops small, roots long, tapered; becoming 6 to 7 type. Tops small, roots long, tapered; becoming 6 to
inches long; deep red with purplish tint. pkt. 10c; 632 Icicle (55 days) The leader among long white radishes; pure white, very crisp and brittle. Grows 6 in. long and about 2 in. out of the ground. Being unusually mild, it is an extremely popular variety amonf

\section{TURNIPS MILD and TENDER}

\section{Culfure}

Sow during cool weather from October to April. For Purple Top, Milan during early winter; and for summer weeks, in drills 12 inches apart; cover the seed lightly unless the season be very dry; thin out the plants to Golden Ball or Purple Top Strap Leaf. Plant $3 \mathrm{lbs}$. to

763 Purple Top White Globe (55 days) By of its uniform shape, attractive color and fine quality flesh. Is sweet and tender and is slow to get pithy $0 \%$ 25c; $2 / 1 / 2$ lb. 50c; 1 lb. $\$ 1.50$ 762 Purple Top Strap Leaved (45 days) An pcellent small-topped flat variety. White in color with
purplish-red top and white flesh. A very mild turnip. about $5 \mathrm{in}$. in diameter and $2 \frac{1 / 2}{\mathrm{in}}$. long. Pkt. $10 \mathrm{c} ;$

\section{Nutritious SQUASH}

\section{Culture}

Sow after danger of frost is past. Light. warm soll :
best. Plant in hills, the bush kinds about 4 feet apart. best. Plant in hills, the bush kinds about 4 feet apart.
and the running varieties from 6 to 9 feet apart. Plant
about $1 / 2$ dozen seeds in each hill and thin to 3 best about $1 / 2$ dozen seeds in each hill and thin to 3 bes
plants. Cutting off the leading shoots of the running maturity of the frult. One ounce of seed will piant from mer varieties and $11 / 2$ pounds of the winter varletles.

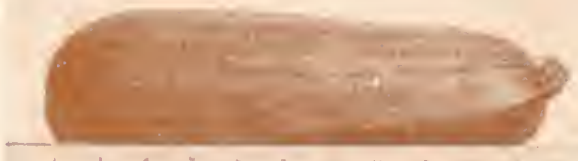

SQUASH ZUCCHINI

692 Italian or Zucchini

very early, prolific. Fruits when Im-

$75 \mathrm{c} ; 1$ 11, $\$ 2.50$
639 Elack Spanish Round

round type of winter radish. Is about days) The short. its color and other characteristics veing the same as the (N\%.25c; 1/4 th. 50c; 1 lb. $\$ 1.50$

633 California Mammoth W:âise (58 days) A very large white radish introduced from the Orient. 7 to 8 in. long, 2 in. thick. Pkt. 10c;

\section{Crimson Giant} and remains in edible condition longer fine mild quality and remains in edible condition longer than most kinds.

628 French Breakfast (25 days) A splendid variety for home use, obiong, bright scarlet, white tip 0 e. 25c; $1 / 4$ 1b. 50c; 1 lb. $\$ 1.50$

626 Scarlet Globe M. T. (23 days) The most popular shipper's strain. Also an excellent strain for
home and market garden. Color rich bright scarlet: home and market garden. Color rich bright scarlet:
flesh white. mild and crisp. Pkt. 1fic:

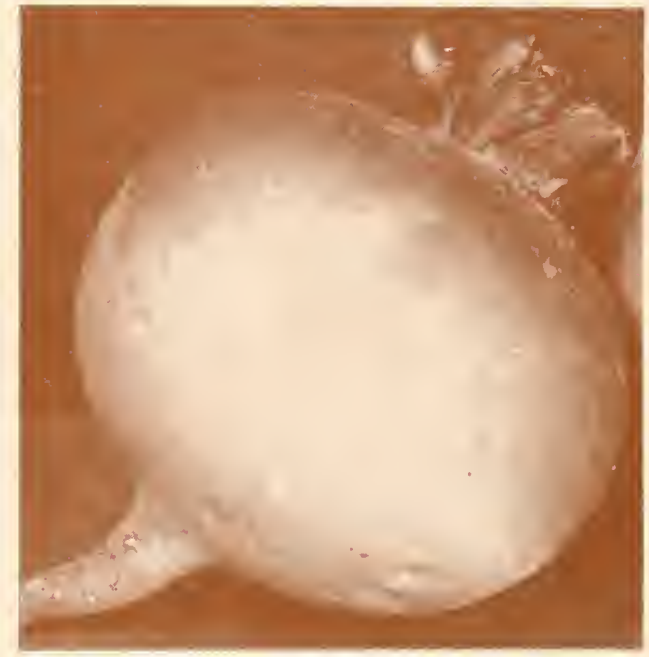

TURNIP PURPLE TOP WHITE GLOBE

685 White Bush Scallop

(a) profusely small, with a distinct scalloped edge. Is very early and has a Oz. 25c; 1/ 1b. $75 \mathrm{c} ; 1$ ib. $\$ 2.50$ 686 Summer Crook Neck (60 days) A favorIte summer squash. Fruits bright sellow, warted. with
Crook neck. Pkt. 1nc; $0 z$ 25c; if lb. 75c; 1 lb. $\$ 2.50$ 701 Hubbard vigorous, productive. Fruit large, weishty, moderately waled, hard shelli color dark bronze Breen. A fle wated thek, dry, colory davored. prato. Frults wesh. $30 \mathrm{c}$, th the $90 \mathrm{c}: 1$ it $\$ 3.00$ 700 Banana (Blue) (105 dass) A deservedly popular variety growing 18 in. to 2 fcet long, 6 to 8 Inches in diameter, skin grayish blue, flesh yellow and
fine grained. Excellent table variety without hard shell. Pkt. 10c:
You Must Try GERMAIN'S NEW SENSATIONAL HYBRID TOMATO 758 Stokescross No. 5

A Grower's Money Maker and Ideal Home Garden Varieiy

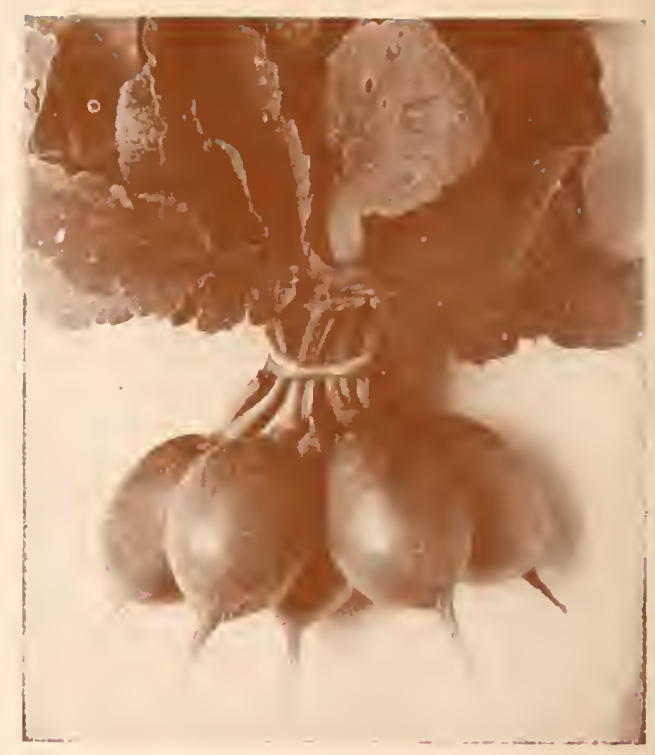

RADISH CRIMSON GIANT

\section{TOMATOES}

\section{Culture}

Sow in hot-bed or frame about Sept. 1 for wintet cri in frostless belts, or in early spring for summer crop and set in pots or in another bed to give them room and make them "stocky." When 5 or 6 inches high if the weather be warm and settled. transplant them to open ground, selecting a rainy day if possible. In the plants 4 feet apart each was. One ounce of seed will produce 3000 plants.

740 Norton

Solid, meaty and A Wilt-Resistant Stone, (120 days) Solid, meaty and Alne aually. A heavy producer. cellent shipper. Also in demand anons canncrs Pkt. $15 \mathrm{c}$

723 Earliana (94 days) Hardy and productive coming into fruit in the shortest time and rapicly shaped. Somerhat flattened, deep scarlet and smooth Pkt. 15c;

$$
\text { Oz. } \$ 1.00 ; 1 / 4 \text { lit } \$ 3.00 ; 1 \mathrm{~b}, \$ 10.00
$$

745 Ponderosa (118 days) Regarded by many as the finest quality of any tomato grown. Very larke pink; it is ideal for the home garden. Fruits weish 9 pink; it is ideal for the home garden. Fruits weigh

\section{Marglobe} canners, shippers and market gardeners. The vine tened rlobe of fine bright scarlet color very firm aud meaty and of the very best quality. Fruits welgh 7 to oz. Pkt. 15c; ()z $\$ 1.00 ; 1 / 4$ ll $\$ 3.00 ; 1$ ill $\$ 10.00$

\section{Pearson Imp.}

(115 days) Frult scarlet, Bccoming very popu and llattened. Very thick skinmed

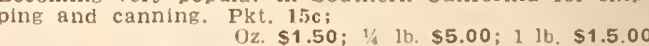

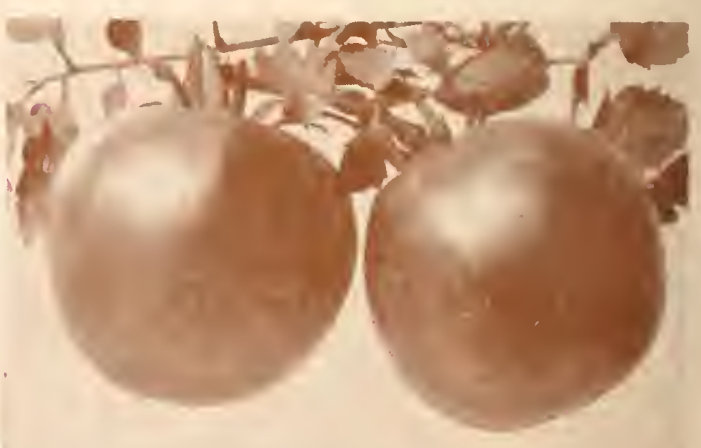

MARGLOBE

724 First Early 194 dasss Fiuit brieht scarlet globe shaped. Solld and sinooth. packs and ships ver the early tomatoes. Pkt. 15ic; 16 \$3.00; 1 lb. $\$ 10.00$ 735 Livingston Globe (112 days) Large fine pink, main crop variety of very mild flavor and used

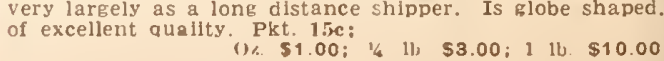


DIC MOND DA

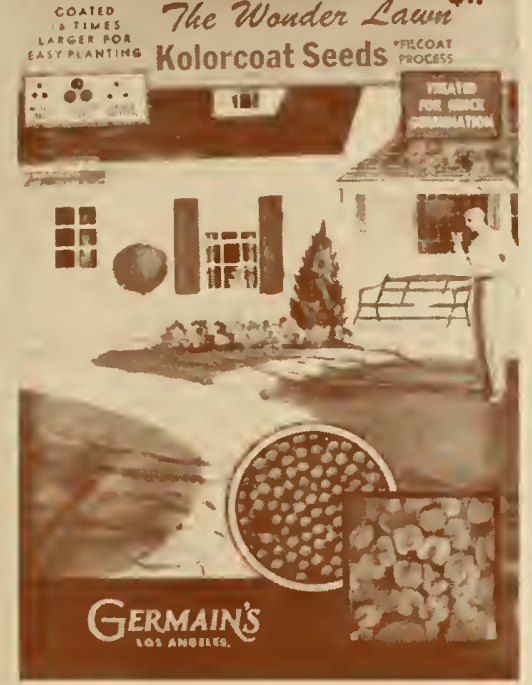

\section{The Wonder Lawn}

$\star$ Deep, Rich Green All Year $\star$ Chokes Back Bermuda $\quad$ Forms Dense Turf

* Requires No Mowing

$\star$ Resists Rough Usage

$\star$ Thrives in Sun and Shade
Dichondra is a low-growing American plant, native to the It is known botanically as Dichondra Repens or D. Repens var. Carolinensis. It makes a dense sod by means of runner-like stems, growing very close to the ground, but never forms a
thick mat like Bermuda grass. The kidney-shaped leaves, about one-fourth inch wlde, and seldom over $11 / 2$ inches in height. have a rich dark velvety-green color. Dicliondra ls tough in texture and hard usage will
Its beautlful appearance. JUMBO (6" $\left.\times 9^{\prime \prime}\right)$ PACKAGE KOLORCOAT DICHONDRA LAWN SEED 250 Square Feet)

1 LB. CARTON KOLORCOAT DICHONDRA LAWN SEE 1250 Square Feet).

In Callfornia and all mild climates dichondra lawns can be started at any tlme of the year. But as the summer is the best growing season for dichondra, spring or early summer
planting glves quickest results. When planting during the colder months, a nurse crop is especially advisable.

summer the East or Middle West we recommend

strong rcot system and for the plants to make seed. rong rcot system and for the plants to make seed. When the

\section{Merian Bluegrass}

Comparing Merion Bluegrass with common Kentucky Blu grass. Merion holds lts color much better through the
"drought" perlod, requires fewer Irrigations, stands closer cutting, and is more resistant to disease. Altogeth

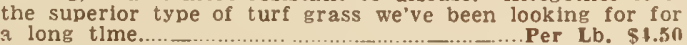

\section{Delta Bluegrass}

A newly developed straln of Bluegrass of excellent quality. very simllar to and possessing to a hleh degree the
splendid characteristic of grnuth and appearance Merion Bluegrass. It is in additlon a more abundant
FREE GRASS SEED FOLDER

Send today for your free copy of "How To Have The Most Beautlful Lawn In Your Nelghborhood." Contains colorful illustrations of beautiful lawns with complete lnmaintain lawns yours for the asking. Send us a card mainta ind your copy of "How to Have The Most Beauuful Lawn In Your Neighborhood" will be mailed Immediately.

Germain's Premium Grass Seed Mixture A mixture of quick growing grasses particularly deslrable for renovating Bermuda Grass lawns in the Fall and green and the plants have an upright growth. Plant at the rate of 1 pound to 150 square feet. 3 Ibs. $\$ 2.25 ;$
in Ib. $\$ 4.25$

All Prices listed are Postpaid

\section{GERMAIN'S EMRALAWN MIXTURE}

This is the finest lawn grass seed mixture avallable. Composed of the best grades of the most desirable lawn
grasses mixed in proper proportions for Callfornia solls grasses mixed in proper proportions for Callornia solls
and conditions. Contalns a hlgh percentage of Kentucky Blue Grass, Rainler Creeping Red Fescue, Astoria Bent. Red Top and Cher, Creeping Red Fescue, Astoras Seed mixture provides a deep green, velvety and permanen

lib. package $\$ 1.40 ; 3 \mathrm{lb}$. package $\$ 4.15 ; 5 \mathrm{lbs} \$ 8.85$;

Golden Wesi Lawn Seed Mixture A general purpose mixture. May be planted in elther sun or shade. Makes an attractive, long lastlng turf.
Plant at the rate of 1 pound to 200 square feet.
$1 \mathrm{lb}$. pakage $\$ 1.25: 51 \mathrm{~b}$. package $\$ 6.00 ; 10$ lbs. $\$ 11.50$

\section{Germain's Parkgreen Lawn Mixture} A fast growlng lawn mlxture. Parkgreen Lawn Mixture contalns Kentucky Blue Grass, Chewings Fescue, Perrennial Rye Grass and clover. The color is bright green, remalning attractive even under adverse growln
conditions. Parkgreen Lawn Mixture grows quickly; mas be mown just three weeks after seedlng. It is tough. hardy, and strong, holding up well in the play-yard. servlce area, and recreation package $85 \mathrm{c:} 3 \mathrm{lb}$. Deckage $\$ 2.40 ; 3 \mathrm{lbs}$. $\$ 4.00$
$10 \mathrm{lbe}$. $\$ 7.76$

Germain's Shady Lawn Mixture Composed of grasses that thrive in the shade. Should $1 \mathrm{lb}$. parkage $\$ 1.15 ; 3 \mathrm{lb}$. package $\$ 3.35 ; 5 \mathrm{lb}$. pkg. $\$ 8.80$

\section{Gras1 Seed for Lawns, Golf Caurses, Etc.}

Kentucky Blue Grass (Poa Pratensis). Premlum grade. The most widely used varlety for general lawn purposes. The follage 1 s faish-green in color. Sow 1 pound to 200 sq. feet.
bluit $\$ 1.00$ White Clover (Trifollum Repens). Used largely as nurse crop ln grass seed mlxtures. Leaves are rounded. to 200 square feet. $\$ 1.25 ; 3$ lbs. $\$ 5.60 ; 10$ lbs. $\$ 11.60$ Red Top (Agrostls alba.) Valuable as a nurse crop In grass seed mlxtures. Leaves have a dull green color Germinates with amazing rapldity. Sow at the rate of Dichondra A dark green creeping plant that qulckly forms a permanent thick lawn of small velvety leaves. Resembles clover but maintains a uniform appearance and requires mowing only twlce a year. Makes a beautiful lawn in both sun or shade. Produces a strong turf and will choke back Bermuda grass. For new lawns DI-
chondra should be sown with clover. chondra should be sown with clover. mately $\div 000$ seeds). Send for Diobondra leeflet.

Bermuda Grass (Cynodon dactylon). Stands much hard usage and is particularly sultable for polo flelds golf course fairways, athletlc fields, and playground areas. Bermuda Grass thrives in hot weather. Plant $2 t$

Alta Fescue Increasingly popular $1 \mathrm{lb} .65 \mathrm{c} ; 10$ lba. $\$ 8.00$ etc., when mixed in equal parts with Bermuda (See Poa Trivialis (Rough-Stalked Meadow Grass). Bluish-green color. Excellent for shady areas. Very fine Ish-green color. Excellent for shady areas. Very fine
texture. Sow at rate of 1 pound to 200 square feet. Chewings Fescue (Festuca rubra var. commuta ta). Flne, wire-like leaves, dark green color and up-
rlght growth. Does well ln shady locations and tolerates a wide range of soll conditlons. Very yaluable for lawns. also useful for greens, fairways, and tees. Sow at rate i lb. \$1.55; 10 lbs. \$15.00 Creeping Red Fescue, Illahee Strain Another pure line selection of creeplng Red Fescue.
color slightly lighter than Rainter but comparable in color slightly lighter than Rainier but comparable in

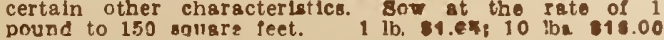

Creeping Red Fescue, Rainier Strain (Festuca rubra stolonlfera). A vlgorous grower, excolor is hardy and is hlghly resistant to disease. The exceedingly uniform. Ralnler does well in the shade and is also hlghly desirable for sandy locatlons because of lts deep-rooting characterlstlcs. An excellent lawn varlety, Reslsts cold, falrly tolerant of heat. Sow at
the rate of 1 pound to 150 square feet. 10 lbe $\$ 18.00$

\section{Meadow Fescue}

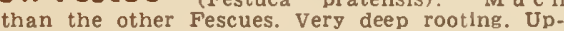
rlght growth, dark green color. Recommended for athletic fields, falrways, and areas subject to hard usage.
Sow at the rate of $i$ pound to 150 square feet.

Seaside Bent (Agrostls marltima). A true surfacecreeping Bent. Very fine-leaved, light green ln color. Makes a thick sod and tolerates very close cutting. Used for golf greens, fairways and lawns. Sow at the

\section{Astoria Bent}

n color than seaside Bent and a more uprlght plant. Very fine-leaved. Recommended for lawns, golf greens and fairways, bowling greens, and polo flelds. Makes a beautiful, thickly matted deep green lawn. Holds pound to 300 square feet. , lb. $\$ 2.05$; ; lbs. $\$ 10.00$ Highland Bent (Agrost1s tenuls). An underground creeping Bent. Light green in color. Very tenacious. creeping Bent. Light green In color.
Makes a permanent turf. Used for service lawns, poln
fields, golf greens, playgrounds and alrports.
$1 \mathrm{lb} \$ \mathbf{1 . 9 0 ;}$ । $1 \mathrm{bs}, \$ 9.25$ Perennial Rye Grass (Lollum perenne). Coarseleaved but falrly hardy. Germinates quickly and under favorable conditions will form a turf ln 18 days. Does not require fertile soll. Sow at the rate of 1 pound
to 100 square feet.

Common Rye Grass (Lollum species). Simllar to perennlal Rye Grass in most respects but is an annual. Hardy and adapted for a temporary lawn or as
nurse crop. Sow at the rate of 1 pound to 10089 . ft.

\section{Clover Seed}

Inoculate Clover Seeds with NITRAGIN Any increase in tonnag Nitragin that all Clover Se Nitragin before planting. By inoculation with Nitragin at a cost of $33 \mathrm{c}$ per acre,
$50 \%$ larger tonnage in Clover crops.

Birdsfoot Trefoil

sls) (Broadleaf Blrdsfoot Trefoil) A long-lived perennial, will stand close pasturlng. Plant 6 pounds per acre.

Birdsfoot Trefoil

nifollus). (Narrow leaf Birdsfoot Trefoil).

A prostrate

Big Trefoil

surface which root at every jolnt. Grows best on damp

Red Clover han most varleties of Alfalfa. Plant $12 \mathrm{lbs}$. to the acre

Mammoth Red Clover or Cow Grass

follum pratense perenne). This plant is a mammoth

1 lb. 65c; 10 lbg. $\$ 6.00$

Subterranean Clover (Trlfollum subterraneum Grows about one foot high, puts out creeping runners has. Plant in fall at rate of 20 to 25 pounds per acre.
$1 \mathrm{lb} 95 \mathrm{c} ; 10$ lbs. $\$ 9.00$ Alsike (Trifollum hybridum). Very hardy, adapted for sowing on cold wet land. Planted at rate of 6 lbs. $\begin{array}{lll}\text { and makes a good bee plant. } \quad \text { lb. } 850 ; 10 & \text { lbs. } \$ 8.00\end{array}$ 


\section{Germain's Clover Seeds (cantinued)}

Sweet Clover pasture and hay crop, blennial, excellent for cover crop and soll bullding. Develops excellent food for bees. Plant $15 \mathrm{lbs}$. per acre. $1 \mathrm{lb}$. $\mathbf{3 5 0}$; 10 . $\mathbf{3 . 2 0}$ Yellow Blossom Sweet Clover (Melllotus of Plcinalls). Simllar, except for color of blossoms, to I lb. $360 ; 10$ lbs. $\$ \mathbf{\$ 3 . 2 0}$ Bur Clover (Medicago Hisplda). Valuable as a green fertllizer and thrives In shade. Also used on hlll lands
with other clover or grasses for pasturage. Plant at the with other clover or grase
rate of 20 lbs. per acre $1 \mathrm{lb} .50 \mathrm{c} ; 10 \mathrm{lbs} . \$ 4.70$

\section{Pasture and day Grasses}

Germaln's are speclallsts in seeds for permanent lrrigated and dry range pastures. For those interested in pasture development "Germaln's Pasture Book" Is avallable. Write for a free copy. It glves complete 1nformation on the agricultural economy of the West is evidenced by the many thousands of acres that are belng planted each year the hardy wild Callfornla grasses that makes very goo pasturage. Plant 10 lbs. to are. 1 lb. $80 \mathrm{c} ; 10$ lbs. $\$ 7.50$

Smooth Brome Grass (Bromus Inermis). Hardy perennial pasture and hay grass. Is resistant to cold and
drought and furnlshes an excellent winter pasture grass or a good hay crop. Plant 20 lbs. per acre.

Mountain Brome (Bromus Marglnatus). A valuable pasture grass, smut resistant, leafy, rapid develop
ing and easy to establish. Plant 10 to 20 lbs. per acre.

Burnef (Poterlum Sanguisorba). This is an excellent plant for both pasture and hay purposes. It is very leafy, does not bloat and is rellshed by all livestock. It will stag green all summer without rain or Irrigatime. Produces qulckly, and has a verg long life.
1 lb. 70 ; 10 lbs. $\$ 6.50$

Alta Fescue (Improved Tall Fescue) (Festuca Elatior). A hardy perennial growlng in most any type of soll or cllmate. Heleht 2 to 4 feet, stays and hay for a wlde range of conditions. Plant in fall. winter or spring at rate of $15 \mathrm{lbs}$. per acre.
$1 \mathrm{lb}$. $\$ 1.05 ; 10 \mathrm{lbs}, \$ 10.00$

Harding Grass (Phalaris Tuberosa Var. Stenoptera). An excellent perennial pasture graes, wlthstands
much hard usage and heavy tramping of stock. Plon in early spring at the rate of 2 to 4 lbs. per acre.

Dallis Grass (Paspalum dllatum). One of the best pasture grasses, furnishes a highly rellished stock feed and it is very hardy. It grows on poor as well as rich
solls and wlll not die out under conditions of drought. Plant 10 lbs. per acre.

Meadow Fescue (Festuca pratensis). A very valuable specles for permanent grass lands and 15
rellshed by livestock both in may and pasture. Sow 15 to $20 \mathrm{lbs}$. per acre on well prepared soll. $10 \mathrm{lbs}, \$ 6.60$

Reed Canary Grass (Pharlaris Arundinacea). quantltes of nutritious lorage. Plant 15 los. per acre.
Alfilaria (Erodium circutarlum or Botrys). One of

Common Rye Grass (Lollum Mult1florum). A quick-growing annual grass attaining a height of $21 / 2$ to 4 ft.; very desirable for temporary meadows or pas
tures. Sow $40 \mathrm{lbs}$. per acre.

Perennial Rye Grass (Lollum perenne). A strons growlng, hardy grass, noted for lts nutritive qualitles Valuable for grazlng or has. Plant 40 lbs. per acre.

Orchard Grass (Dactylls glomerata). Valuable If planted alone or mlxed with other grasses. Seed should be broadcasted at the rate of $15 \mathrm{lbs}$. per acre. 500 : 10 lbs. $\$ 4.50$

Tall Oat Grass (Arhenatherum elatlus). A hardy upright perennial excellent for llight, sandy solls. Gives heavy yleld of hay, stands pasturing well and furnlshes
abundant grazing. Plant 30 to 40 pounds per acre.
ab. 600 ; 10 lbs, $\$ 5.60$

Tall Oat Grass, Tualatin Strain an Improved straln. Seed is hulled and therefore 20 pounds are suf ficlent to plant an acre. $\quad 1$ b. $\$ 1.00 ; 10$ lbs. $\$ 9.60$

Crested Wheat Grass (Agropgron Cristatum). It has demonstrated its abllity to withstand drought
in this country; has a very extenslye root system. A
perennial and long lived. Plant $11 / 2$ in. deep and 10 lbs. per acre when broadcasted or drilled. 10 lbs. $\$ 8.50$
$1 \mathrm{lb}, 70 \mathrm{c} ; 10$

Rescue Grass (Bromus Catharticus). A short lived perennial. Helght of 2 to 3 feet, growth starts in early
fall. Produces excellent forage on good soll rellshed by fall. Produces excellent forage on good soll rellshed by
livestock. Plant 15 to $25 \mathrm{lbs}$, per acre.

Timothy

Thrlves best (Phelum pratense). Excellent for $h$ a $y$.

Red Top (Agrotis alba). Does best on moist or even marshy land. Sow $10 \mathrm{lbs}$. of seed to the acre. $1 \mathrm{~b}$. 90 c 10 lbs. $\$ 8.60$

Quantity Prices and Samples Sent on Request. Write for "Germain's Pasture Book"

\section{Cover Crop Seeds}

Prices on cover crop seeds listed below are postpald in quantltles up to and including ten pounds. Cover crop and we therefore request buyers of sack lots or over to
wrlte us for spcclal quotations. Our stocks are all write us for spcclal quotations. Our stocks are all purlty and germination and free from weeds.

\section{FALL COVER CROP}

Purple Vetch

and heavy nitrogen and humus producer Rapld grower hay and sllage. Plant 40 lbs. per acre. 1 lb, 30c; 10 lbs. $\$ 2.50$

Common Vetch (Vicla Sativa). Plant at the rate

$\begin{array}{llll}\text { of } 60 \mathrm{lbs} \text {. to the acre. } & \text { 1 lb. 30c; } 10 \text { lbs. } \$ 2.60\end{array}$

(VIcla villosa). A winter hardy va-
rlety. Plant 40 to 45 pounds per acre.

Hubam Clover Annual legume, excellent cover

crop for fall or spring plantlng. ${ }_{1 \mathrm{lb}}$ 36c; $10 \mathrm{lbs}, \mathbf{\$ 3 . 3 0}$

Melilotus Indica (Sour Clover). An annual legume, dependable and heavy in production of nitrogen
and Ereen manure. Plant $20 \mathrm{lbs}$, per acre.
ib. 30 ci 10 lbs. $\$ 2.50$ Bur Clover (Medicago Hispida). Second only to Purple Vetch in nitrogen production per acre. Broad-
past at the rate of $20 \mathrm{lbs}$. per acre.

Sweef Clover A blennlal legume having a deep sturdy tap-root penetrating plough soles and hardpans. May be used as a spring cover crop. $1 \mathrm{lb}$. 36c; 10) lb. $\$ 3.20$ White Mustard, Yellow Seeded (Brassica alba). Generally ready to plough under in 3 months.
Plant 8 to 10 lbs, per acre. August to December Trieste Black Mustard (Brassica ntgra) A great. er tonnage can be obtalned from this varlety than the
Yellow variety but its growth is slower.
1 lb. 40; 10 lbs. $\$ 3.60$

Field Mustard, Wild Black Seeded (Char. lock). Successiully used as a non-leguminous cover
crop. Canadian Field Peas (Pisum arvense). May be planted in cold weather and furnish a most valuable SPRING COVER CROP

Blackeye Beans Belong to the Cow Pea family and are often used for cover crop with satisfactory re-
sults. Plant 30 lbs. to the acre. Sesbania (Besbanla Exaltata). A cover rop that is especlally adapted to hot climates. It is a leguminous
plant. Plant at the rate of $12 \mathrm{lbs}$. to the acre.
Lespedeza (Korean) (Lespedeza stipulacea). Hay and forage crop. Very hardy and grows on poorer Hubam Clover (Melllotus Hubam). An annual. Blossoms flrst season planted, therefore desirable for
aplarlsts. Heavy ylelder and excellent for hay, pas. aplarists. Heavy ylelder and excellent for hay, pas-
turage and cover crop. Plant 12 lbs. per acre. Ladino Clover (Trifollum Repens Var.) A mam. moth White Clover growing rapldly and furnishing an
abundance of tender green feed. Plant 3 lbs per acre.
l ib. $\$ 1.70 ; 10$ ibs. $\$ 16.50$ Thrlves best on molst, loams soll. Sow early in the
spring or fall. Plant 10 to 12 pounds per acre.

\section{Alfalfa Seed}

Alfalfa African an Impruved straln. Tests show greater ylelds per acre than other varletles under warm
weather conditlons. Alfalfa India 1 lb. 60c; 111 1bs, $\$ 4.76$ tmoroved straln giving re1 lb. 50c; 111 the, $\$ 476$ A fosistant to bacterlal wilt and to Golde. 900 : 10 ltws. $\$ 8.76$ Golden West Brand Hairy Peruvian A heavler producer in warm cllmates. $1 \mathrm{lb}$. 50c; $111 \mathrm{H1}, \$ 4.76$ Premium Brand Chilean (Common) The leadIng varlety in use, gives most satisfactory results under
a wide varlety of conditions.

\section{Sarghums and Sudan}

Write for quantity prices. SACCHARINE SORGHUMS

Early Amber Furnishes most nutritive torake Grows ten to twelve feet high. Sow broadcast for for-
age at the rate of 5 lbs. per acre in drills $3 \frac{1}{2}$ to 4 feet
apart.
1 lb. 30 ; 10 lbs. 52.60 Honey Sorghum For ensilage and for syrup pur. poses. It Is a fine varlety for sllage purposes, having
slender leafy stalks. When the crop is to be used for
fodder or sllage it is usually planted in rows 3 to $3^{1 / 2}$ feet apart, using up to 5 lbs. of seed per acre. 1 1 1 h. $300 ; 10$ lh. $\$ 2.50$

\section{NON-SACCHARINE SORGHUMS}

Double Dwarf Milo Maize (Certifted No. 38 ) Grows 2 to $2 \frac{112}{2}$ feet tall and therefore can be comblined Hegari The heads grow very erect. It is droukht resisting and stands some alkall. Plant slx pounds to Egyptian Corn The 1 lb. 26c; 10 ths. $\mathbf{\$ 2 . 0 0}$ compact heads and the seed is flat and pure whlte plant the same as Mllo Malze.

\section{SUDAN}

Sudan Grass Grows on a wide range of solls from sand to slay, and produces from four to slx cuttlngs of hlghly nutritlous hay per acre. Sow 15 to 20 ths.
of seed per acre.
1 lb. 250; 11 lbs. $\mathbf{5 2 . 0 0}$ Sudan Grass Certified No. 23 Has ylelded on actual test about $20 \%$ more than ordinary Sudan. Sweet SUDAN Grass Is sweet and Juicy and more palatable to llvestock than Common Sudan, Is
disease resistant, remalns growing longer, has broader leaves, heavler and taller stalks and stools more readils

\section{Field Carn}

NOTE-Prices on fleld corns listed below are postpaid in quantitles up to and including 10 pounds. If larger quantitles are desired, write us for special prices. I
grown for the corn, fleld corn should be drilled in rows three feet apart, and two feet apart in rows, requlring about ten pounds per acre. If grown for ensllage, the rows should not be over one foot a part, and thirts inches
apart in the rows, requirlng 50 to 75 pounds to the acre Hybrid Ensilage Corn No. 520 This yellow Dent Corn is an extremely heavy producer of sllage. It Ing in about 110 days. 1 lb. 30c: 10 lbs $\$ 2.60$ Double Cross Hybrid No. $\mathbf{4 7 0}$ We recom. sults. Plant 30 lbs. to the acre. 1 lb. 360; 10 lbs. $\$ 3.00$ mend this hybrid corn for planting for graln. It is a Hybrid Ensilage Corn U. S. 52 A H 1 gh 19 recommended ensilage hybrld with heavg broad leaves.
carrled to the ground and remanlng green untll after
the ear is dented. A good grain producer of mild-season maturity, widely adapted to soll and cllmattc conditions. Hickory King, White Th1s corn is entirely dis. tInct from all other varletles, having large kernels with

\section{ENSILAGE CORN-Open Pollinated} Orange County Prolific Orange Counts Proliflc is a Callfornla product of the white dent varlety mended for ensilage purposes. 1 lb. 25c; 10 lbs. $\mathbf{\$ 2 . 0 0}$ Mexican June Corn, White very early and hardy, stalks growing to an average helght of 7 or 8 feet and producing 30 to 60 bushels of corn per acre
This corn ts also used for roasting purposes. 1 lb. 26c; 10 lbs, \$2.00 King Philip, Yellow This is a hard yellow flint corn and is generally referred to as a ninety-day corn.
It is drought resisting and will glve a falr yleld where $\begin{array}{llll}\text { It } & \text { most corns are a fallure. } & \text { lb. 25c; } 10 \text { lba. } \mathbf{\$ 2 . 0 0}\end{array}$ yellow dent varlety and is about a 90 day corn. $\$ 2.60$ 


\section{GERMAIN'S PLANTING CHART}

"T.-In the quantity column means these varietles are to be sown in hot beds and trallsplanted to the field

\begin{tabular}{|c|c|c|c|c|c|c|c|c|}
\hline VARIETF & $\begin{array}{l}\text { Seed for } \\
100 \mathrm{ft} \text {. row }\end{array}$ & $\begin{array}{l}\text { Seed for } \\
1 \text { acre }\end{array}$ & $\begin{array}{l}\text { Time of } \\
\text { Planting }\end{array}$ & $\begin{array}{l}\text { Put Rows } \\
\text { A part }\end{array}$ & $\begin{array}{l}\text { 1.eave Plts. } \\
\text { A part in } \\
\text { Row }\end{array}$ & $\begin{array}{l}\text { Crop Matures } \\
\text { in about }\end{array}$ & $\begin{array}{l}\text { Depth of } \\
\text { Planting } \\
\text { in Inches }\end{array}$ & $\begin{array}{l}\text { I pproximate } \\
\text { Yield } \\
\text { Per Acre }\end{array}$ \\
\hline 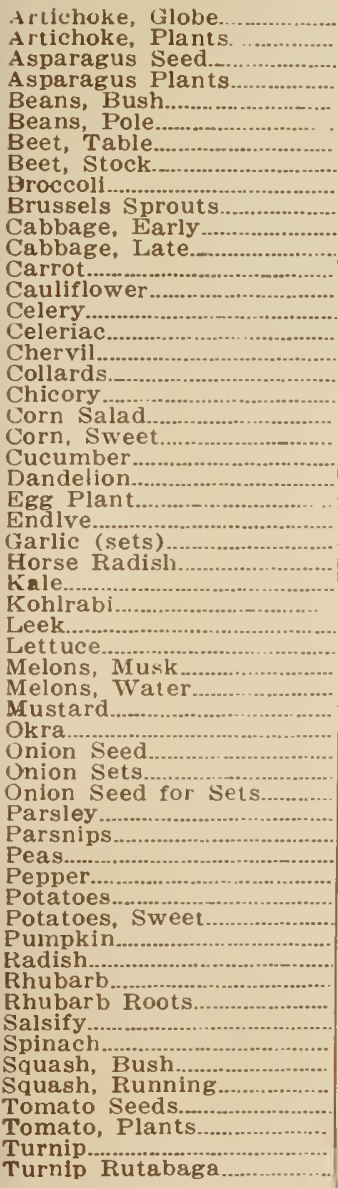 & $\begin{aligned} & 2 \text { Pkts. } \\
& 32 \text { Plants } \\
& 1 \text { oz. } \\
& 32 \text { Plants } \\
& 1 \text { lb. } \\
& 3 / 4 \text { lb. } \\
& 2 \text { oz. } \\
& 2 \text { oz. } \\
& 1 \text { Pkt. } \\
& 2 \text { Pkts. } \\
& 1 \text { Pkt. } \\
& 1 \text { Pkt. } \\
& 1 \text { oz. } \\
& 1 / 2 \text { oz. } \\
& 2 \text { Pkts. } \\
& 1 \text { Pkt. } \\
& 3 \text { Pkts. } \\
& 1 \text { Pkt. } \\
& 1 \text { oz. } \\
& 1 / 2 \text { lb. } \\
& 2 \text { Pkts. } \\
& 1 \text { Pkt. } \\
& 1 \text { Pkt. } \\
& 1 \text { oz. } \\
& 2 \text { Pkts. } \\
& 70 \text { Plants } \\
& 2 \text { Pkts. } \\
& 1 \text { Pkt. } \\
& \text { 1/2 } \text { oz. } \\
& 2 \text { Pkts. } \\
& 3 \text { Pkts. } \\
& 2 \text { Pkts. } \\
& 1 \text { oz. } \\
& 1 \text { Pkt. } \\
& 1 \text { oz. } \\
& \text { 1/2 oz. } \\
& 2 \text { lbs. } \\
& 2 \text { oz. } \\
& 1 \text { Pkt. } \\
& 2 \text { Pkts. } \\
& 1 \text { lb. } \\
& 1 \text { Pkt. } \\
& 5 \text { lbs. } \\
& 70 \text { Plants } \\
& 2 \text { Pkts. } \\
& 1 \text { oz. } \\
& 2 \text { Pkts. } \\
& 33 \text { Roots } \\
& 1 \text { oz. } \\
& 1 \text { oz. } \\
& 2 \text { Pkts. } \\
& 2 \text { Pkts. } \\
& 1 \text { Pkt. } \\
& 35 \text { Plants } \\
& 2 \text { Pkts. } \\
& 2 \text { Pkts. }\end{aligned}$ & 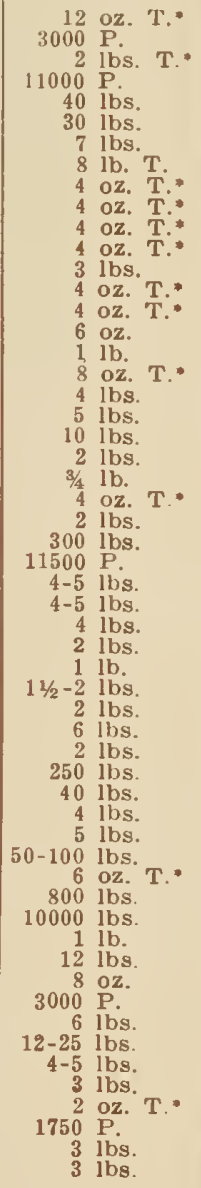 & $\begin{array}{l}\text { October to May. } \\
\text { December to April } \\
\text { February to May } \\
\text { December to May } \\
\text { Jan. to September } \\
\text { Jan, to September } \\
\text { All Year } \\
\text { September to May } \\
\text { Nov. to April } \\
\text { October to May } \\
\text { All Year } \\
\text { All Year } \\
\text { All Year } \\
\text { June to January } \\
\text { January to May } \\
\text { January to May } \\
\text { January to August } \\
\text { All Year } \\
\text { September to May } \\
\text { Feb. to Nov. } \\
\text { March to Sept. } \\
\text { March to Sept. } \\
\text { Sept. to April } \\
\text { January to August } \\
\text { August to May } \\
\text { Sept. to March } \\
\text { December to May } \\
\text { All Year } \\
\text { All Year } \\
\text { Sept. to April } \\
\text { All Year } \\
\text { March to July } \\
\text { March to July } \\
\text { All Year } \\
\text { April to July } \\
\text { Sept. to April } \\
\text { All Year } \\
\text { All Year } \\
\text { All Year } \\
\text { All Year } \\
\text { All Year } \\
\text { January to July } \\
\text { Dec. to Sept. } \\
\text { March to July } \\
\text { March to Augusı } \\
\text { All Year } \\
\text { January to April } \\
\text { Decomber to May } \\
\text { February to Oct. } \\
\text { All Year to Oct. } \\
\text { February to Oct. } \\
\text { February to Aug. } \\
\text { February to Aug. } \\
\text { March to Oct. } \\
\text { All Year } \\
\text { All Year }\end{array}$ & 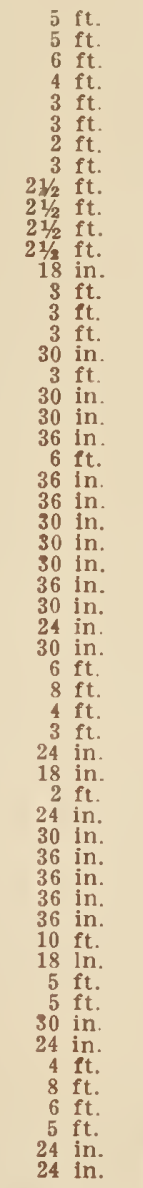 & 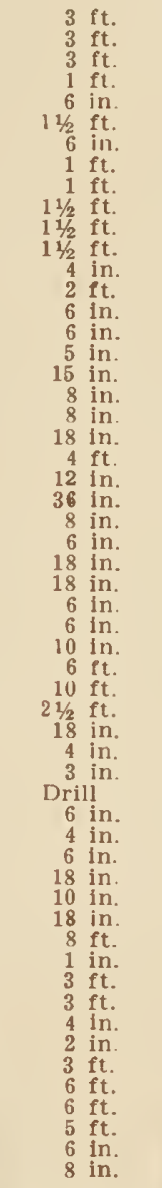 & $\begin{array}{l}\text { 2nd Spring } \\
\text { Next Spring } \\
\text { Third Spring } \\
\text { Next Spring } \\
2 \text { to } 3 \text { Months } \\
2 \text { to } 3 \text { Months } \\
3 \text { to } 31 / 8 \text { Months } \\
4 \text { to } 6 \text { Months } \\
31 / 2 \text { Months } \\
5 \text { Months } \\
3 \text { to } 4 \text { Months } \\
4 \text { to } 5 \text { Months } \\
4 \text { Months } \\
4 \text { to } 6 \text { Months } \\
4 \text { to } 5 \text { Months } \\
4 \text { to } 5 \text { Months } \\
2 \text { Months } \\
4 \text { Months } \\
2 \text { to } 3 \text { Months } \\
2 \text { to } 3 \text { Months } \\
21 / 8 \text { to } 3 \text { Months } \\
2 \text { to } 3 \text { Months } \\
3 \text { Months } \\
4 \text { Months } \\
3 \text { Months } \\
5 \text { to } 6 \text { Months } \\
6 \text { Months } \\
2 \text { to } 3 \text { Months } \\
4 \text { Months } \\
4 \text { Months } \\
2 \text { to } 3 \text { Months } \\
3 \text { to } 4 \text { Months } \\
3 \text { to } 4 \text { Months } \\
3 \text { to } 5 \text { Weeks } \\
3 \text { Months } \\
41 / 2 \text { to } 6 \text { Months } \\
2 \text { to } 4 \text { Months } \\
2 \text { to } 3 \text { Months } \\
3 \text { Months } \\
4 \text { Months } \\
2 \text { to } 4 \text { Months } \\
3 \text { to } 4 \text { Months } \\
2 \text { to } 3 \text { Months } \\
3 \text { to } 4 \text { Months } \\
3 \text { to } 4 \text { Months } \\
1 \text { to } 2 \text { Months } \\
2 \text { nd Spring } \\
\text { Next Spring } \\
4 \text { Months } \\
40 \text { to } 65 \text { Days } \\
2 \text { Months } \\
3 \text { to } 4 \text { Months } \\
4 \text { to } 5 \text { Months } \\
2 \text { to } 3 \text { Months } \\
3 \text { to } 4 \text { Months } \\
3 \text { to } 4 \text { Months }\end{array}$ & 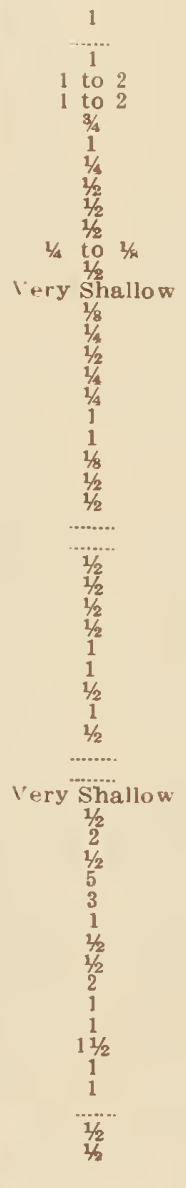 & 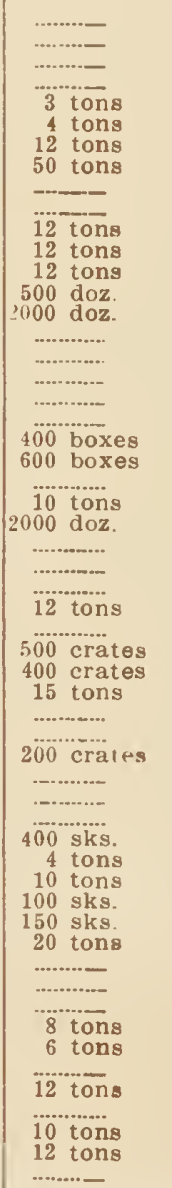 \\
\hline
\end{tabular}

SPACING AND NUMBER PLANTS PER ACRE

\begin{tabular}{|c|c|c|c|c|c|c|c|c|c|c|c|c|c|c|c|c|c|}
\hline & $\begin{array}{l}\text { Vistance } \\
\text { Apart }\end{array}$ & & $\begin{array}{l}\text { No. of Trees } \\
\text { or Plants } \\
\text { per Acre }\end{array}$ & & $\begin{array}{c}\text { Distance } \\
\text { Apart }\end{array}$ & & $\begin{array}{c}\text { No. of Trees } \\
\text { or Plants } \\
\text { Der Acre }\end{array}$ & $\begin{array}{l}\text { Distsnce } \\
\text { Apart }\end{array}$ & $\begin{array}{c}\begin{array}{c}\text { No. of Trees } \\
\text { or Plants } \\
\text { per Acre }\end{array} \\
\end{array}$ & $\begin{array}{c}\text { Distance } \\
\text { Apart }\end{array}$ & $\begin{array}{c}\text { No. of Trees } \\
\text { or Plants } \\
\text { per Acre }\end{array}$ & & $\begin{array}{c}\text { Distance } \\
\text { Apart }\end{array}$ & & \begin{tabular}{|c} 
No. of Trees \\
or Plants \\
per Acro
\end{tabular} & $\begin{array}{c}\text { Distance } \\
\text { Apart }\end{array}$ & $\begin{array}{l}\text { No. of Trees } \\
\text { or Plante } \\
\text { ver Acre }\end{array}$ \\
\hline $\begin{array}{l}3 \\
4 \\
6 \\
1 \\
11 / 2 \\
2 \\
2 \\
21 / 2\end{array}$ & $\begin{array}{l}\text { by } 4 \\
\text { by } 4 \\
\text { by } 6 \\
\text { by } 1 \\
\text { by } 11 / 2 \\
\text { by } 1 \\
\text { by } 2 \\
\text { by } 21 / 2\end{array}$ & $\begin{array}{l}\text { In. } \\
\text { in. } \\
\text { in. } \\
\text { ft. } \\
\text { ft. } \\
\text { ft. } \\
\text { ft. } \\
\text { ft. }\end{array}$ & $\begin{array}{r}522,720 \\
392,040 \\
174,240 \\
43,560 \\
19,360 \\
21,780 \\
10,890 \\
6.960\end{array}$ & $\begin{array}{l}3 \\
3 \\
3 \\
31 / 2 \\
4 \\
4 \\
4 \\
4\end{array}$ & $\begin{array}{l}\text { by } 1 \\
\text { by } 2 \\
\text { by } 3 \\
\text { by } 31 / 2 \\
\text { by } 1 \\
\text { by } 2 \\
\text { by } 3 \\
\text { by } 4\end{array}$ & $\begin{array}{l}\mathrm{ft} . \\
\mathrm{ft} . \\
\mathrm{ft} . \\
\mathrm{ft} . \\
\mathrm{ft} . \\
\mathrm{ft} . \\
\mathrm{ft.} \\
\mathrm{ft.}\end{array}$ & $\begin{array}{r}14,520 \\
7,260 \\
4.840 \\
3,555 \\
10,890 \\
5,445 \\
3,630 \\
2,722\end{array}$ & 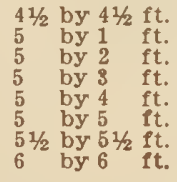 & $\begin{array}{r}2,150 \\
18,712 \\
4,356 \\
2,904 \\
2,178 \\
1,742 \\
1,440 \\
1,200\end{array}$ & $\begin{array}{rrrr}6 & \text { by } & 7 & \mathrm{ft} . \\
6 & \text { by } & 8 & \mathrm{ft} . \\
6 & \text { by } & 9 & \mathrm{ft} . \\
6 & \text { by } & 10 & \mathrm{ft} . \\
7 & \text { by } & 7 & \mathrm{ft} . \\
8 & \mathrm{by} & 8 & \mathrm{ft} . \\
9 & \mathrm{by} & 9 & \mathrm{ft} . \\
10 & \mathrm{by} & 10 & \mathrm{ft} .\end{array}$ & $\begin{array}{r}1,031 \\
907 \\
806 \\
726 \\
888 \\
680 \\
537 \\
436\end{array}$ & $\begin{array}{l}11 \\
12 \\
14 \\
15 \\
16 \\
161 / 8 \\
17 \\
18\end{array}$ & $\begin{array}{l}\text { by } 11 \\
\text { by } 12 \\
\text { by } 14 \\
\text { by } 15 \\
\text { by } 16 \\
\text { by } 161 / 2 \\
\text { by } 17 \\
\text { by } 18\end{array}$ & $\begin{array}{l}\text { ft. } \\
\text { ft. } \\
\text { ft. } \\
\text { ft. } \\
\text { ft. } \\
\text { ft. } \\
\text { ft. } \\
\text { ft. }\end{array}$ & $\begin{array}{l}360 \\
302 \\
222 \\
193 \\
170 \\
160 \\
150 \\
134\end{array}$ & $\begin{array}{l}19 \text { by } 19 \mathrm{ft} . \\
20 \text { by } 20 \mathrm{ft} . \\
25 \text { by } 25 \mathrm{ft} . \\
30 \text { by } 30 \mathrm{ft} . \\
33 \text { by } 33 \mathrm{ft} . \\
40 \text { by } 40 \mathrm{ft} . \\
50 \text { by } 50 \mathrm{ft} \\
60 \text { by } 60 \mathrm{ft} .\end{array}$ & $\begin{array}{r}120 \\
108 \\
69 \\
48 \\
40 \\
27 \\
17 \\
12\end{array}$ \\
\hline
\end{tabular}

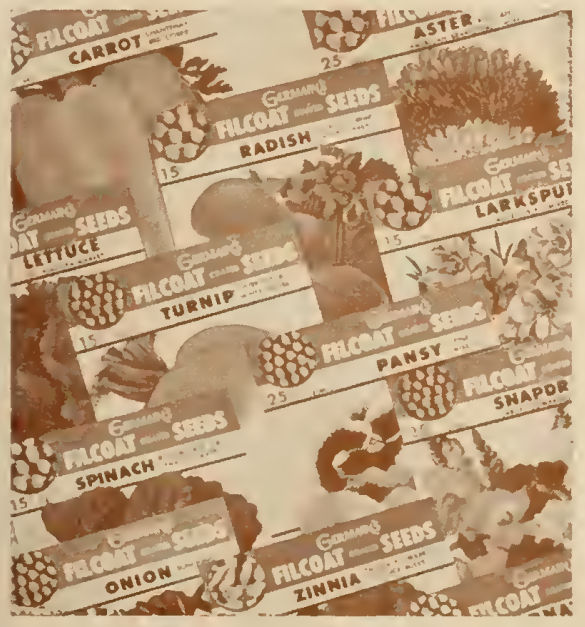

\section{GERMAIN'S AMAZING COATED SEEDS $S_{\substack{\text { PROCEB: } \\ \text { FILCOA. }}}$ TO grow FINER, LARGER, HEALTHIER \\ FLOWERS and VEGETABLES in YOur GARDEN}

Before being offered to the gardening public, Germain's Filcoat Coated Seeds were thoroughly tested by commercial growers. The results were amazing. Germain's Coated Seeds produced healthier, sturdier plants and larger yieldOutstripping even plants transplanted at the same time. Test after test showed that no other seed gave results so outstanding as the modern, up-to-the-minute scientifically protected - Germain's Coated Soods. ("Filcoat Process)

\section{FLOWER SEEDS}

2044 C Alyssum Lilac Queen .......................... I5t. 2300 C Aster American Branching Mixed.......Pkt. 25c 2630 C Bachelor Button Double Mixed.............Pkt. $15 \mathrm{c}$ 2570 C Carnation Marguerite Mixed...................... 25 c 2830 C Delphinium Hybridum Mixed.......................... 25c 3250 C Lorkspur Tall Double Mixed...................Pkt. 15c $3540 \mathrm{C}$ Pansy Fine Mixed..................................... 25k 3600 C Petunia Choice Single Mixed.............. Pkt. 15c 3632 C Phlox Drummondi Large Mixed..........Pkt. 25c 3665 C Poppy Improved Shirley Mixed............. Pkt. 15c 2130 C Snapdragon Large Flowering Tall

$$
\text { Mixed }
$$

3950 C Stocks Lorge Ten Weoks Mixed
Pkt. 25c

*REG. U. S. PAT. OFF.
4279 C Sweet Peas Giant Early Flowering ......Pkt. 25e 4100 C Zinnia Dahlia Flowered Choice Mixed Pkt. $15 \mathrm{c}$

\section{VEGETABLE SEEDS}

60 C Broccoli Green Sprouting............

22 C Cabbage Copenhagen Market................Pkt. $15 \mathrm{c}$

156 C Carrot Danver's Half Long........................... I $5 \mathrm{c}$

164 C Carrot Red-Cored Chantenay...............Pkt. I5c

344 C Lettuce Los Angoles Market_....... Pkt. 15c

$510 \mathrm{C}$ Onion Bunching ….............................. 15c

621 C Radish Scorlot Turnip White Tipped....Pkt. I5c 658 C Spinach Bloomsdale or Savoy Leaved Pkt. 15c

723 C Tomato Earliana _.......__._._......... $15 \mathrm{c}$

763 C Turnip Purple Top White Globe .......Pkt. 15c 


\section{GERMAIN'S \\ California's \\ Since 1871}

\section{American Beauty Asters}

A renowned cut flower strain producing very large densely double flowers on long stems. The flowers are of the American branching type but much larger

2260 American Beauty Asters. Mixed colors.

Crega ar "Ostrich Feather" Aster (Wilt Resistant)

Large, shaggy flowers just like an ostrich feather fan! Rich color assortment

2271 Crimson. Pkt. 15c 2274 Rose. Pkt. 15c

2272 Flesh. Pkt. 15c 2277 White. Pkt. $1.5 \mathrm{c}$

2273 Lavender. Pkt. 15c 2280 Crego's or Ostrich

2276 Purple. Pkt. 15c Feather Mixed. Pkt. 15c

Special

Ostrich Feather Aster Collection

No. 24

5 Packets (a $75 \mathrm{c}$ value) for $50 \mathrm{c}$

The loveliest and most free blooming of the "Ostrich Feather" Aster, will bring you lots and lots of shaggy blooms for cutting and one packet of mixed colors.

\section{Acraclinium-Strawflowers}

Bedding, Cutting Full Sun

Pretty daisy-like flowers of satiny appearance that last for vears when dried. For drving cut in bud.

2009 Giant Flowered Hybrids. Extra large flowers. New mixture includes white chamois flesh and rose.

\section{Ageratum - Floss Flower

$$
\text { Low Border }
$$

Annual Low Border full Sun Fragrant, soft plush-like little flowers. Their dense all summer.

2024 Blue Cap. Close heads of rich blue flowers.
Compact dome-shaped flowers. 8 in. Compact dome-shaped flowers. almost hide the bushy 9 in. plants. Pkt. $15 \mathrm{c}$ 2049 Midget Blue. Very dwarf 3 inch plants.
True Ageratum Blue. Wonderful for edging. Pkt. ISc

\section{Aluspere Sweet Alyssum or}

\section{Annual Low Edging Sun or half Shade} Pretty, sweetly scented, useful for borders, edging, window boxes, hanging baskets and rock

2039 Sweet. (Maritimum) Spreading habit, 8 in. tall. . $35 \mathrm{c}^{\circ}$ Pkt. $10 \mathrm{c}$ 2041 Little Gem. Erect. 6 in. Pure white, perfect 2045 Carpet of Snow. Very dwarf. 4 in. Spreads $\begin{array}{ll} & \text { in carpet-like moss of white, entire season. Pkt. 10c } \\ 2044 \text { Lilac Queen. Lavender Lilac. } & \text { Pkt. } 10 \mathrm{c}\end{array}$ 2043 Violet Queen. Bright violet flowers in large 2047 Saxatile. $\quad$ Pkt. $15 \mathrm{c}$

\section{Amaranthus-Amaranth} Background

Full Sun Ornamental foliage. Highly decorative for background. 2056 Tricolor. (Joseph's Coat) Showy variegated red.
green and white.

\section{Anchusa - Italian}

$$
\text { Eackground }
$$

sprays of forget-me-not-like flowers from early 2069 Italica. Tall 5 it. bush, with rich clear blue sprays of flowers. Effective as background. Pkt. 15c

\section{Anemane - Windflower}

$$
\text { Beds and Cutting Sun or Hall Shade }
$$
poppy-shaped flowers, easily grown from seed

Monarch Strsin Mixed. Rose. salmon. Crimson

\section{California Giant Asters}

The immense, feathery. Chrysanthemum.like flowers measure from five to six inches. The stems are low branched, heavy, two feet in length and form no later. als, hence no disbudding is necessary. Informal flowers, of great size, charming and graceful. Blos. soms full to the center, with broad curled and inter
laced petals, borne on long, heavy, non-lateral stems

2241 Rose Marie. Lovely giant bright rose flowers.

2234 Light Blue. Delightful sky blue. Pkt. $25 \mathrm{c}$

2233 El Monte. The richest crimson-a super giant 2232 Los Angeles. Feathery, silver pink, huge 2235 Peach Blossom.

Florists' pink. Pkt. 25c; 3 for $60 \mathrm{c}$ 2236 Purple. Intense blue purple. Pkt. 25c; 3 for $60 \mathrm{c}$ 2239 White. Snowy white. Pkt. 25c; 3 for $60 \mathrm{c}$ 2240 New California Giants. Super-fine mixed! Oz. $75 \mathrm{c}$; Pkt. 25c; 3 for $60 \mathrm{c}$

\section{New Princess Asters}

The newest and loveliest of the Crested Center Asters. especially prized for cut flowers. Blossoms $3^{\prime \prime}$ to $3 \frac{1}{2}$

2344 Linda. Clear rose (New) Pkt. $25 \mathrm{c} ; 3$ for $60 \mathrm{c}$ 2349 Bonnie. Salmon rose, golden center. Pkt. 15c 2348 Anne. Peach.

2346 Barbara. Orchid.

2347 Golden Sheaf. Yellow.

2351 Princess Mixed.

Pkt. $15 c$

Pkt. $15 c$

Pkt. 150

\section{Arctatil-Large African Daisy}

Annual Bedding, Border Sun

2205 New Hybrid Mixed. Larqe showy flowers in 2204 Grandis. A wealth of large daisy-like flowers. white with a steel blue reverse, excellent for cutting.

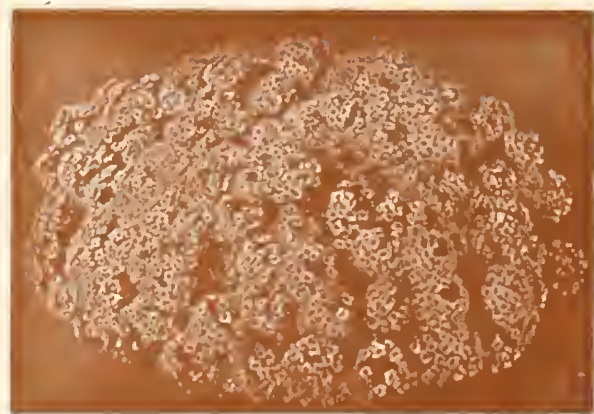

ALYSSUM

\section{Asparagus - Fern Asparagus}

Perennial

House Plant, Vine

Shade

2218 Plumosus. Handsome fern-like house plant. Out doors a feathery vine, excellent for shady locations.

2219 Sprengeri. Fine pot plant. $\quad$ Pkt. 20c

\section{Bachelar Buttons - Corn-Flower}

Annual Borders, Culting Sun An old favorite, succeeding anywhere. A dependable

2623 Blue Boy. Very double intense blue. Pkt. 15 2627 Snow Man. Snow white.

2625 Red Boy. Ruby Red.

2622 Jubilee Gem. Dark Blue Dwarf.

2624 Double Deep Blue. Extra large ruffled blooms. 2630 Double Choice Mixed. Oz. 70c: Pkt. 10c Special

-Again Flower Garden This osscriment combines in one package many of flower arrangement-provides a wealth of lovely

\section{No. 24B}

Window Box and Edging Flowers Delightful low flowers for edgings and containers.
3 Pkts. for 60s; Pkt. 25c Cut-and-Come-Again Flower Garden

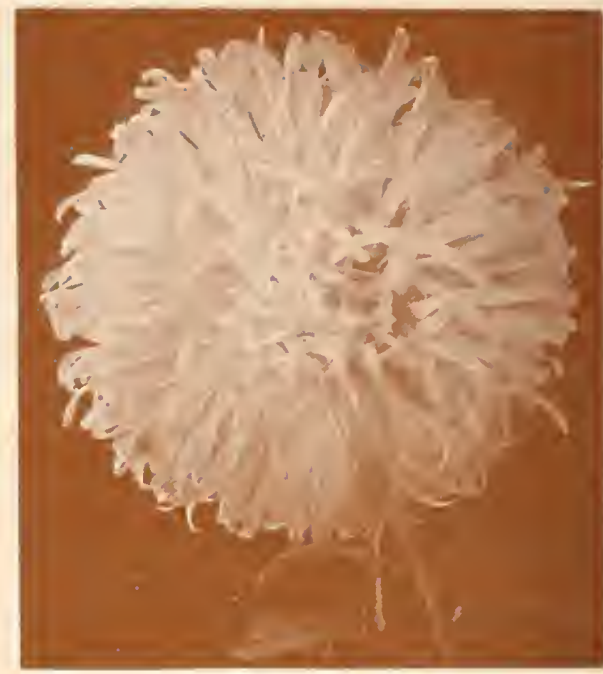

ASTER CALIFORNIA GIANT

\section{American Branching Asters (Wilt Resistant)} This famous strain of branching Asters is deservedly 2291 Crimson. Intense, crimson red: Pkt. 15c 2292 Flesh. Clear even light pink! Pkt. 15c 2293 Lavender. Blue Lavender! Pkt. $15 c$ 2294 Purple. Perfect flower. Deep violet! Pkt. 15c 2295 Rose Pink. Charming, bright rose: Pkt. 15c 2296 White. Large, well-formed flowers! Pkt. 15c 2300 American Branching. All colors mixed. Pkt. 15c 2320 Aster King Mixed. Mixed W. R. Pkt. $15 \mathrm{c}$

\section{Balsam-Ladies' Slipper}

Annual Borders, Bedding Sun The brightly colored double flowers on bushy plants with fleshy stems and shiny bright green leaves. 2410 Double Camellia Flowered Mixed. 241I Double Camellia Flowered Choice Mixed. Reselected strain.

\section{Beganias}

Perennial Edging, Borders Hall-Shade For low borders, bedding and edging there are fow plants more effective than shiny-leaved, bright colored

2422 Luminosa. Dark scarlet.

Pkt. 25c

2428 Carmen. Carmine pink.

Pkt. $25 c$

2430 Semperflorens Mixed. A choice assortment of

\section{Bellis-English Daisy}

Perennial Border, Edging Sun The lovely, Easter-flowerina, low growing daisy of 2445 Pernnis Double Mammoth Mixed. Pkt. $25 \mathrm{c}$

\section{Cactus}

Perennial House and Garden Sun and Shade 2490 Choice Sorts Mixed. Leafless succulents in massive, round, cylindrical, flat and angular forms, typical favorites in every California garden. Ideal as potted plants in all seasons, they're decorative--
require very little care.

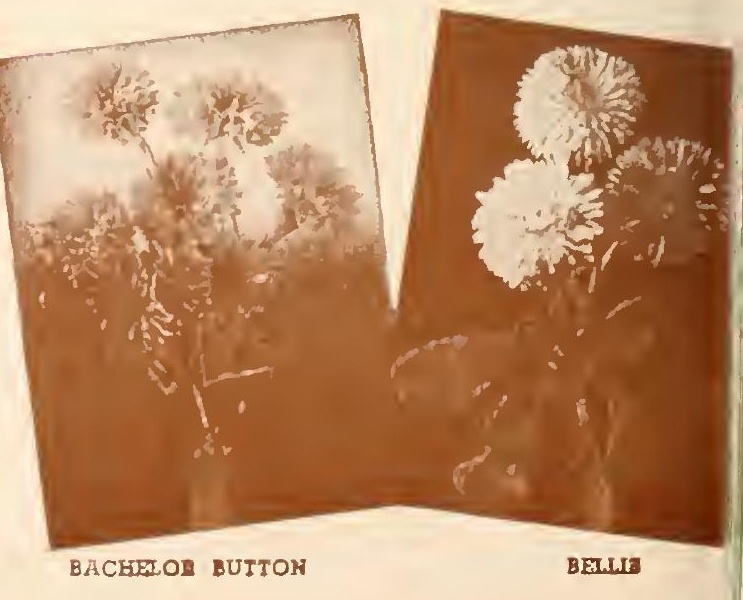


ORDER BLANK FOR PLANTS GERMAIN's

LOS ANGELES 21, CALIFORNIA

Send the following Prepaid and Delivery Guaranteed

\begin{tabular}{|c|}
\hline Date of Order \\
\hline
\end{tabular}

R. D. or Street and No.

Post Office State

Express Office

If Different from P.O. and give address in full.

Terms-Send Remittance In full with order. We cannot accept C. O. D. orders. All shipments You Day nothlng extra.

If merchandlse is to be sent to another address, please print or

SHIP TO

Name.

Address

Clty and

Clty and
State......

In case we are out of a variety you order, we shall send another variety of the same color and equal or higher value, as most of our customers prefer it. if you do NOT wish us

NON-WARRANTY. Germain's Inc. gives no warranty express or implled, as to the productiveness of seedn, bulbs or plants it sells and will not be in any way responstble for the crop. Our liablitty in all instances is limited to the purchase price of the seeds, bulbs or piants.

\section{Tree Rases}

For complete description of all tree roses listed below, please refer to rose section elsewhere in this catalog.

\section{PATENTED VARIETIES}

BEST REGARDS (Pat. 652)

NR202........\$4.00 each CANDLE GLOW (Pat. Pend.) NR205........ 4.00 each CAPISTRANO (Pat. 922) NR203........ 4.50 each HEART'S DESIRE (Pat. 501) NR209....... 4.00 each LOWELL THOMAS (Pat. 594) NR212....... 4.00 each MISSION BELLS (Pat. 923) NR216...... 4.50 each PEACE (Pat. 591)

SAN FERNANDO (Pat. 785)

SAN GABRIEL (Pat. 860)

SAN LUIS REY (Pat. 861) NR217........ 4.50 each NR220....... 4.00 each NR221 1....... 4.00 each NR222....... 4.00 each TEXAS CENTENNIAL (Pat. 162) NR226........ 4.00 each All Verreties Listed Above Will Be Found In Color In The Rose Section of This Catalog.

\section{POPULAR VARIETIES}

CHRISTOPHER STONE

ETOILE DE HOLLAND

PICTURE

PRES. HOOVER

SNOWBIRD

TALISMAN

VILLE DE PARIS
MRS. E. P. THOM
NR232 $\ldots . . . . . \$ 3.75$ each NR234....... 3.75 each NR239........ 3.75 each NR242....... 3.75 each NR245........ 3.75 each NR249....... 3.75 each NR251 ....... 3.75 each NR255....... 3.75 each
Any of the above Popular Varieties SIX FOR \$20.00

\section{Culture and Care of Tree Rases IMPORTANT}

After planting Tree Roses please be sure to observe the following: Keep top covered with a piece of light burlap or muslin and sprinkle the top twice a day, particularly in sunny weather, until the buds begin to swell and foliage begins to show.

Then handle like any other rose bush.

Also keep plant well watered and tie to a strong stake to eliminate the possibility of breakage due to strong winds.

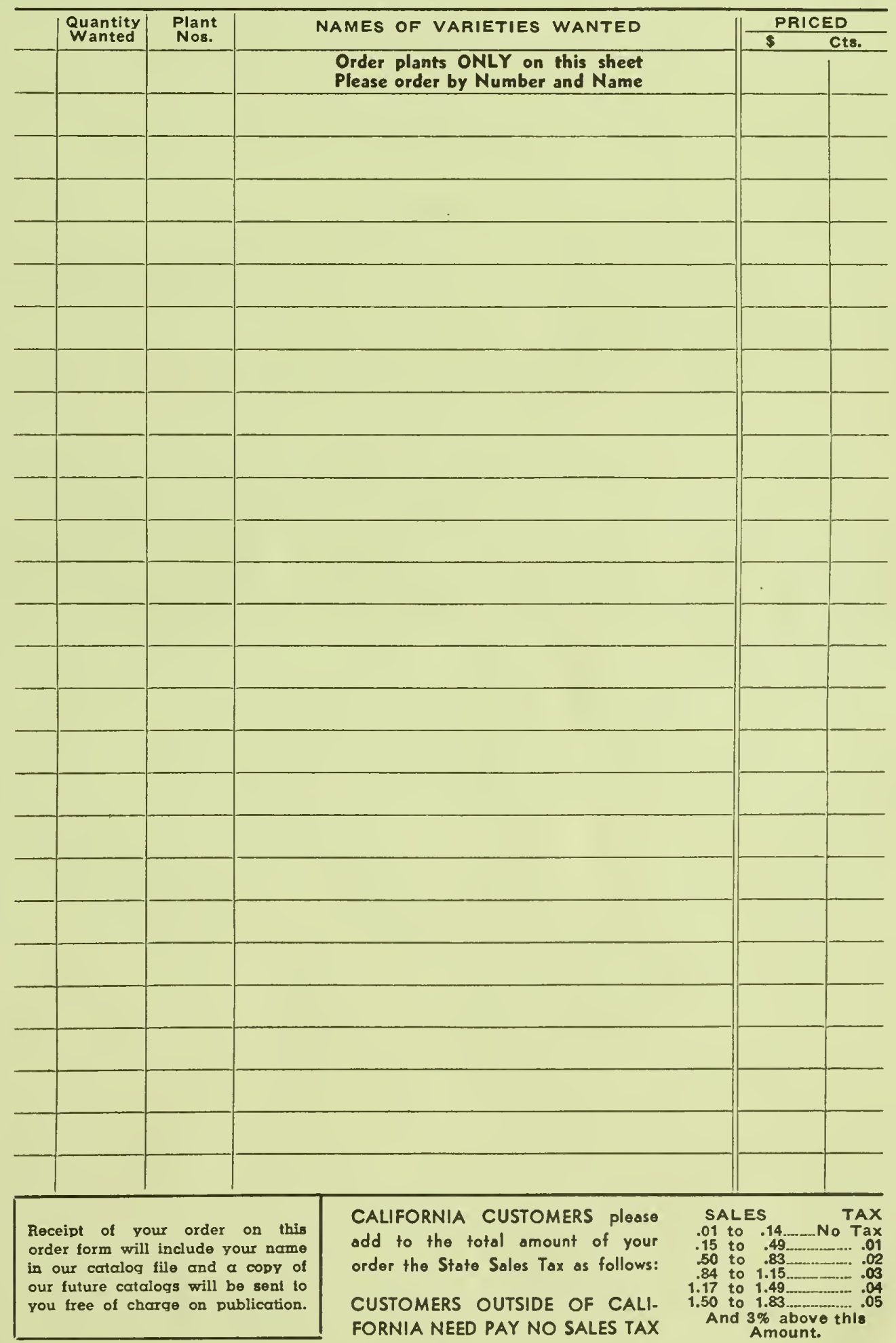




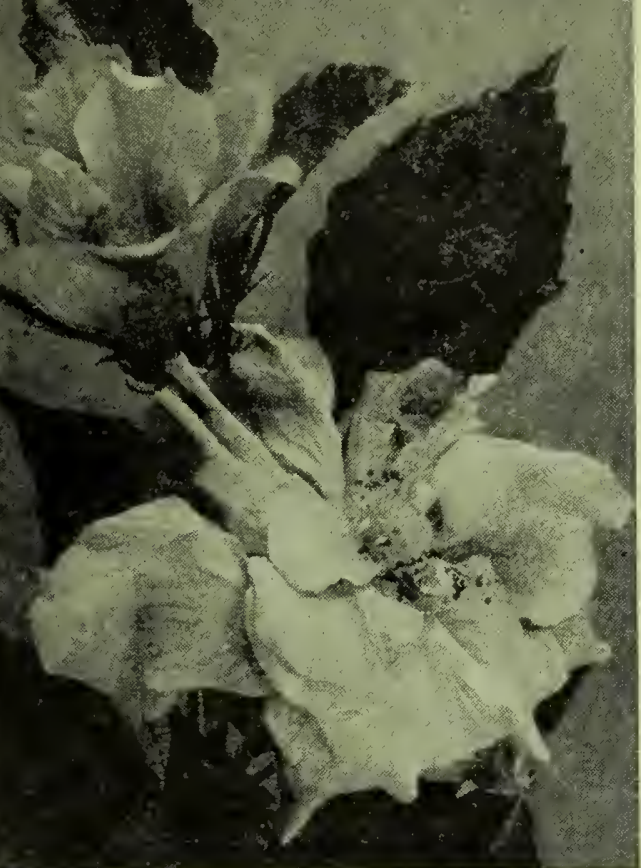

HIBISCUS

\section{FUCHSIAS}

For shady places, Fuchsias are indispensable. They bloom over a long period.

CHIEF-Double flowers of dark rich violet. Petals flushed cerise. Dark carmine sepals. NS401 GYPSY QUEEN-Double flowers of rosy mauve. Sepals deep red. NS404 HOLLYDALE-Medium pink corolla. Sepals several shades darker. Double flowers. NS406 PHENOMENAL-Bright scarlet sepals, purple corolla; double. NS408 STORM KING-Double. White center, scarlet sepals. Very fine. NS410

\section{Trailing or Basket Varieties} BUTTERFLY - Single corolla rose bengal. Sepals and base of corolla, crimson. NS412 CASCADE_Large single flowers of pink, salmon and cerise.

NS4 13

MARINKA-Large single flowers of vivid red. NS4 14

MOLESWORTH-Double corolla snow white. Broad sepals are scarlet.

Any of the above, $\$ 1.00$ each.

\section{HIBISCUS}

Showy flowers of large size which bloom over a long period. Full sun.

AGNES GAULT_-Immense single coral pink flowers.

NS423

PEACHBLOW-A pleasing shade of light pink. Double.

NS424

SINGLE RED - The brightest colored and most profuse bloomer of all.

NS425

DOUBLE RED-Rich double red.

Any of the above, $\$ 1.25$ each.

\section{NERIUM-(Oleander)}

Brilliant showy blossoms that appear at practically all seasons of the year.

ATROPLENISSIMA-Dark blood.

MRS. ROEDING_Double salmon.

SINGLE WHITE-Clean flowers.

DOUBLE PINK-A bright shade.

NS440

NS441

NS442

Any of the above, $\$ 1.15$ each.

\section{PLUMBAGO}

CAPENSIS_Fast growing, semi-climbing shrub. Beautiful azure blue flowers. NS445.

$\$ 1.15$ each

WILMOTTIANA-Deep blue flowering shrub that bears masses of flowers throughout a large part of the year.

$\$ 1.15$ each

\section{PYRACANTHA}

ROSEDALE-Bears long branches of deep orangered berries which are useful for holiday decoration. NS453.

ALL ITEMS POSTPAID

ORDER BY NAME AND NUMBER

\section{Deciduous Flowering Shrules and Trees}

\section{PHILADELPHUS}

BELLE ETOILE (Mock Orange) - Its arching branches are loaded in May and June with fragrant flowers. Color is white with purple shadings at the base of each petal.

NS449.

$\$ 1.00$ each

\section{LAGERSTROEMIA CREPE MYRTLE}

INDICA-A small growing tree that bears large clusters of pink crepe-like flowers. NS492 $\$ 1.20$ each

\section{MAGNOLIA}

GRANDIFLORA (Southern Magnolia) - Large glossy green-leafed tree. Blooms are waxy and pearly white. The fragrance is sweet. NS493.

$\$ 1.40$ each

\section{WEIGELA}

Shrubs that bear large quantities of trumpetshaped flowers in the Spring.

EVA RATHKE-Carries clusters of ruby red flowers.

NS397

$\$ 1.15$ each

ROSEA-Arching branches bear clusters of trumpet-shaped rose pink flowers.

NS398.

$\$ 1.15$ each

\section{FRENCH LILACS}

CLARKE'S GIANT (PIant Patent 754)-The finest lilac in existence today. Individual flowers are $1 \frac{1}{4}$ to $1 \frac{1}{2}$ inches across, and flower trusses measure from 8 to 10 inches long. The color is a beautiful soft Gentian blue. Fragrant. Single. NS500.

$\$ 3.00$ each

ELLEN WILMOTT-Large double flowers of pure alabaster white. Very free flowering and free branching.

NS503

$\$ 2.00$ each

\section{VIBURNUM}

OPULUS (Eastern Snowball) - Its large white flowers which appear in the late Spring make a spectacular showing. Hardy. NS396..

$\$ 1.15$ each

\section{Vines}

\section{BIGNONIA}

CHERERE_-Produces great panicles of bloodred flowers all through Summer and Fall. NS473.

$\$ 1.25$ each

\section{GELSEMIUM}

SEMPERVIRENS - (Caroline Jessamine). Small glossy green foliage, clear yellow trumpetshaped flowers. NS475 $\$ 1.15$ each

\section{LONICERA}

HALLIANA - (Honeysuckle). flowers which turn to yellow. NS477

Fragrant white STEPHANOTIS

FLORIBUNDA-Bears great quantities of snowy white waxy flowers. Exotic fragrance. NS481. 4" pots $\$ 1.90$ each

\section{TECOMA}

CAPENSIS - (Cape Honeysuckle). Blooms in the Winter. Bears large quantities of bright red trumpet-shaped flowers.

NS479

$\$ 1.15$ each

\section{WISTARIA}

SINESIS_Large panicles of blue flowers that hang gracefully. Available January to April. Bare root. Two years old.

NS480

$\$ 2.20$ each

\section{Grapes \\ FOREIGN VARIETIES}

Should be planted on a well-drained soil in a sunny location. In Pacific Coast States they are planted in practically all locations.

BLACK HAMBURG - Large bunches of coal black round berries, firm, juicy and sweet.

NA952

BLACK MONUKKA-Seedless fruit of medium size in large clusters; almost black, sweet, juicy. NA95 4

BLACK MUSCAT - The flavor of this variety even beats the white Muscat. Bears heavy. NA956 FLAME TOKAY - Very large bunches; large berries. Thick flame colored skin; sweet flesh. NA958

LADY FINGER-The grape is large, fully two inches long. Long greenish amber berries.

NA960

MALAGA - Very large loose bunches, with large, oval, yellowish green berries. Early.

NA962

MUSCAT_Long and loose bunches. Large ber ries slightly oval, pale amber when ripe.

RIBIER - Extra large berries on medium sized bunches. Intense blue-black color NA966 THOMPSON SEEDLESS - This favorite seedless grape, is ideal for home growing. Very large bunches of small, greenish-yellow berries. Early.

Any of the above 3 for $\$ 1.00 ; 10$ for $\$ 2.75$

THE NEW "CARDINAL" GRAPE

A cross between the Ribier and Tokay, this variety is the earliest Grape of all. Much larger than any early Grape. Its flavor is very distinctive bearing some resemblance to Muscat with the Ribier's crispness.

NA973.

3 for $\$ 1.75$

THE FAVORITE AMERICAN GRAPE

CONCORD - Black in color, with a bluish bloom, borne profusely in medium sized bunches. Its rich flavor is just the same when grown here as in the East.

NA950................ 3 for $\$ 1.40 ; 12$ for $\$ 5.00$

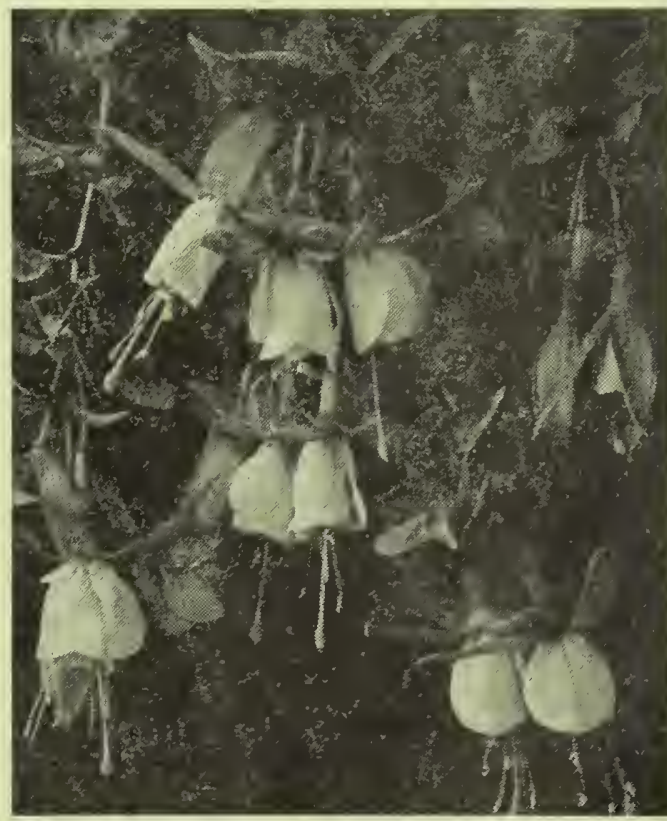

FUCHSIA 


\section{ALL ITEMS POSTPAID}

NOTICE: Deciduous fruit trees can be shipped only during the months of January, February and March.

\section{ALMONDS}

For best results two varieties of Almonds should be planted together to insure pollenization.

NE PLUS ULTRA-The nuts are large and long with a soft corky shell. NF804 NONPAREIL_- The most valuable commercial AImond for California. Large, smooth, plump kernel. TEXAS PROLIFIC-Medium size nut. Of great value in pollenizing other varieties NF808 Any of the above, $\$ 1.50$ each.

\section{APPLES}

Do best in colder sections and higher altitudes. DELICIOUS-Brilliant red, slightly splashed with yellow. GIANT HONEY_-The outside color is green with a red cheek. The meat is greenish white and delicious.

GRAVENSTEIN - Skin greenish yellow, striped with red shadings; flesh yellow. NF817 JONATHAN - Firm sweet white flesh. Skin red. $\quad$ NF818 YELLOW DELICIOUS-Combines all desirable features of its parent with handsome color. NF823 YELLOW NEWTON PIPPIN-Flesh cream white, firm, tender.

TRANSCENDENT CRABAPPLE - Large red and yellow. Makes the finest preserves of any
variety.

Any of the above, $\$ 1.50$ each.

\section{APRICOTS}

For early production of fresh fruit, the Apricot leads the field.

MOORPARK - Very large, deep yellow fruit, a
beautiful deep red on the sunny side. beautiful deep red on the sunny side. NF827
ROYAL_Skin dull yellow with orange cheek faintly tinged with red. Very sweet. NF826 TILTON - One of the largest Apricots. Very finely flavored, sweet and juicy. NF830 Any of the above, $\$ 1.50$ each. CHERRIES

Prefer higher altitudes and cold climate for best results.

BING-Large, dark reddish black fruit, firm flesh, fine flavor. NF832 MORELLO - The best sour cherry; dark wine-red, flesh tender and melting. NF834 ROYAL ANNE - Pale yellow with bright red cheeks. Flesh firm and sweet. NF837 Any of the above, $\$ 1.75$ each.

FRENCH PRUNE

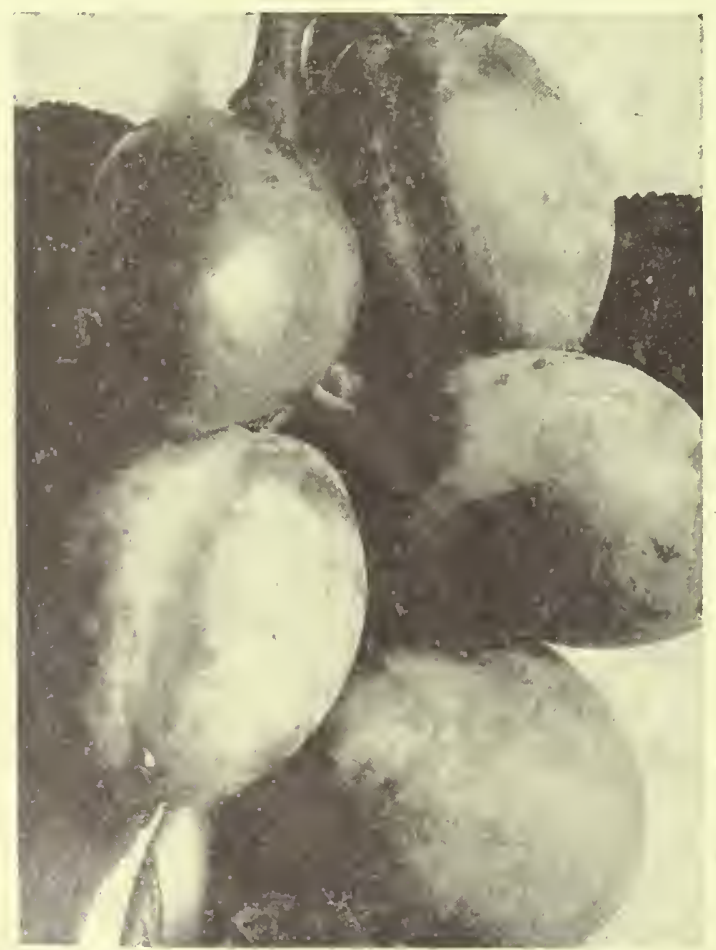

ORDER BY NAME AND NUMBER

FIGS

Southern California is noted for its fig production. BROWN TURKEY_-Purple color turning deeper as it matures. KADOTA-For eating, canning, pickling. Fruit green, flesh pink. NF841 MISSION - Fruit medium to large, mahoganyviolet in color, with brownish-red flesh. NF842 Any of the above, $\$ 1.75$ each.

\section{NECTARINES}

A popular fruit, flavor sweeter than a peach GOLD MINE-Red and yellow fruit, with juicy white flesh, exceptional flavor. NF846 GOWER-Fruit very firm, freestone, and splashed with crimson. Delicious flavor. NF847 STANWICK - Pale skin, greenish-white shading into deep rich violet in the sun; white flesh.

\section{Any of the above, $\$ 1.50$ each. PEACHES \\ FREESTONE VARIETIES}

BABCOCK-Will bear a crop every year regard less of winter temperature. White fleshed free. stone.

EARLY ELBERTA-Identical to Elberta except it ripens about seven days earlier. Yellow, firm, juicy, rich.

NF856

ELBERTA - Fruit is large, golden yellow with brilliant shades of red; firm, juicy. NF857 J. H. HALE - Very large, round yellow fruit sweet and melting. NF858 MILLER'S LATE-A fine large yellow freestone. RIO OSO GEM (Patent No. 84)_Flesh is yellow, firm and has as fine a flavor as any peach you ever ate.

Any of the above, $\$ 1.50$ each.

\section{CLING PEACH VARIETIES}

ORANGE CLING-Fine flavor with deep yellow

flesh.

Deep yellow flesh, of fine texture. NF867

WBERRY CLING - Large yellow, striped

White flesh, red around pit.
Any of the above, $\$ 1.50$ each. FLOWERING PEACH

Nothing is more beautiful than a flowering Peach in Spring when in blossom.

DOUBLE WHITE-Large flowers.

EARLY RED-A clean ruby red.

PEPPERMINT STICK-Red and white.

SAN JOSE PINK-Double pink. Any of the above, $\$ 1.65$ each. PEARS

Pears thrive best in higher altitudes where they are subjected to cold winters.

BARTLETT_Large, smooth. Clear yellow. White flesh. Juicy, buttery and highly perfumed. NF852 COMICE-Comice bears fruit of good size with a yellow skin lightly shaded with russet. NF85 WINTER NELIS-The finest winter variety produced. Medium sized round fruit. Yellowish skin.

\section{Any of the above, $\$ 1.50$ each. PRUNES}

FRENCH IMPROVED-Dark blue fruit; tender skin. Rich and sugary. Dark purple, large and sweet. NF873 Any of the above, $\$ 1.50$ each.

\section{PLUMS}

DAMSON_Excellent for preserves, jellies, pies. Fruit small, roundish; skin purple. NF875 SANTA ROSA-Deep purplish crimson. Yellow flesh, streaked crimson. NF877 SATSUMA-Large fruit; solid dark red color from skin to pit. Firm, juicy. NF878 Any of the above, $\$ 1.50$ each. POMEGRANATE

WONDERFUL-Rich-gamet pulp with an abundance of juice, dark as port wine.

\section{NF892. \\ WALNUTS}

$\$ 1.15$ each

EUREKA-Large oblong, soft shell, tightly sealed. Tree vigorous grower, blight resisting. NF882.

$\$ 3.00$ each

PLACENTIA - A favorite in Southern California.

Soft shell, large white meats of excellent quality. NF883.

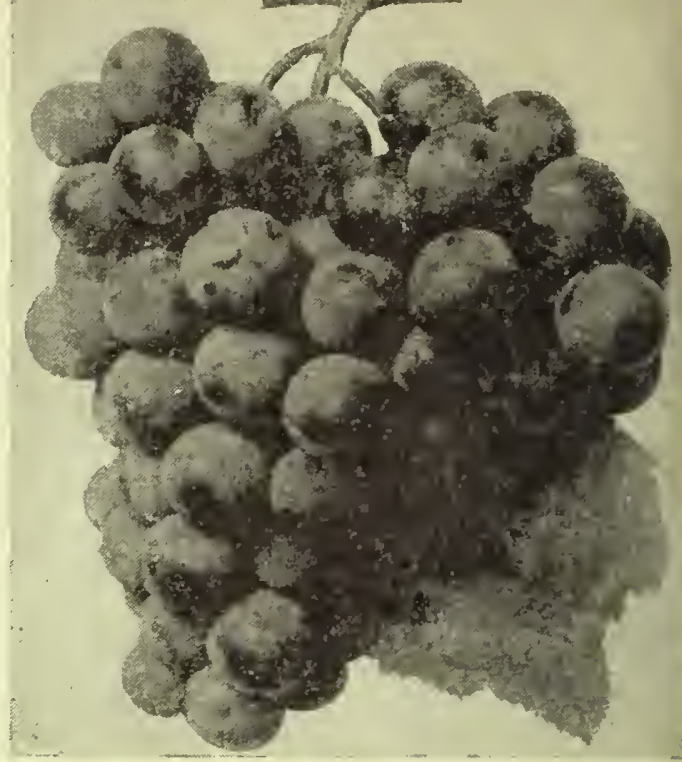

CONCORD GRAPES

\section{ASPARAGUS}

Plant in rich soil in furrows 6" to $10^{\prime \prime}$ deep. Set 12 to 16 inches apart. Cover with 2 inches soil. Fill in as the plants grow until the trench is filled. Rows 4 feet apart. Do not cut the first season.

PARADISE-Produces heavy crops with improved flavor: green stalks.

NB746............. 25 for $\$ 1.25 ; 100$ for $\$ 3.50$; RHUBARB

1000 for $\$ 27.50$

GIANT CHERRY - Stalks of excellent flavor

NB755............... 3 for $\$ 1.00 ; 10$ for $\$ 2.75$

\section{STRAWBERRIES}

University varieties of Strawberries that have been thoroughly tested by the University of California.

DONNER-The leading variety for Southern California. Fruit bright red of conic shape. Very prolific. NB733 LASSEN-A fine variety for general use. Very vigorous and productive. Good shipper. NB734 SHASTA-The largest berry of the University type. Fruit bright red, extra large with fine flavor. Recommended for coastal conditions.

TAHOE-Bears over a very long period. Firm

flesh, sub-acid flavor, fine quality. NB738

Any of the above, 25 for $\$ 1.25 ; 100$ for $\$ 4.50$; 1,000 for $\$ 30.00$

\section{BLACKBERRY}

MACATAWA-Fruit very sweet and firm. It bears through June and July.

NB703................. 5 for $\$ 1.00 ; 10$ for $\$ 1.75$ BOYSENBERRY 100 for $\$ 12.00$

Largest of all berries. The fruit is identical in color with Youngberries, but more highly flavored.

NB706................. 5 for $\$ 1.00 ; 10$ for $\$ 1.75$;

\section{YOUNGBERRIES}

00 for $\$ 12.00$

The fruit is very juicy, with a rich blended flavor.

NB7 18 ................ 5 for $\$ 1.00 ; 10$ for $\$ 1.75$;

LOGANBERRIES

100 for $\$ 12.00$

THORNLESS (Plant Pat. No. 82)-Produces over a longer period than the common Loganberry.

NB721 .............. for $\$ 1.00 ; 10$ for $\$ 3.00$ RASPBERRIES

MUNGER - The fruit is black, never dry or seedy. NB71 4.................5 for $\$ 1.00 ; 10$ for $\$ 1.75$; 100 for $\$ 12.00$

CUTHBERT-The fruit is red, sweet, very large, firm and of fine flavor.

NB710......... 5 to $\$ 1.00 ; 10$ for $\$ 1.75$;

\section{CURRANTS}

100 for $\$ 12.00$

PERFECTION - Good quality; bright red; flavor rich, mild and sub-acid. NB7 40

\section{GOOSEBERRIES}

OREGON CHAMPION-Medium large, round, fine quality, productive.

\section{NB740 HORSERADISH}

3 for $\$ 1.40$

BOHEMIA-Grows best where it can be supplied with abundant moisture.

NB752. 6 for $\$ 1.00$ 


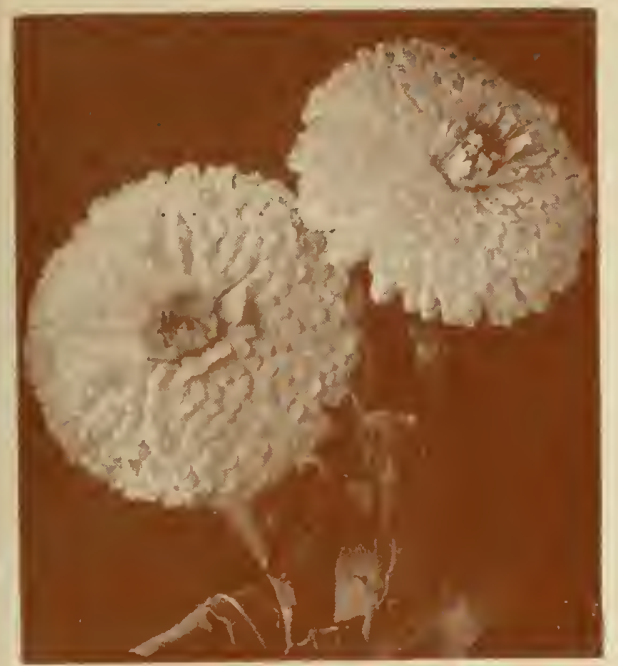

CALENDULA ART SHADES

Calcealaria - Purse Flower

Annual Window, Greenhouse
One of the best loved indoor pot plants. Flowers One of the best loved indoor pot plants. Flowers
shaped like miniature purses. 2481 Hybrida Superba. A splendid strain, lovely colors. Prized pot plant. A splendid strain, Pkt. $\$ 1.00$ Cardinal Climbers - Ipomea Sloteri Annual Climber Full Sun 3211 Cardinalis. Grows 30 feet tall! Filled with a
blaze of cardinal flowers.

\section{Coleus - Flame Nettle}

Annual Foliage, Bedding Plants

2733 New Hybrids. Rainbow-hued summer Sun and potted plant! Bright yollow, maroon, green and

\section{Calliopsis}

Annual Bedding, Cutting Full Sun ers are cut may be kept blooming until late autumn. 2521 Choice Double Mixed. Double, semi-double. 2520 Choice Sorts Mixed. Per Oz. 75c; Pkt. 10c

\section{Campanula - Canterbury Bell}

Annual, Biennial Border Shade One of the grandest of old-time favorites, reach a shaped tlowers during spring and summer. shaped flower, surrounded by calyx of similar colors. Looks like cup and saucer!

2540 Cup and Saucer Mixed. 1/8 Oz. 60c; Pkt. $15 \mathrm{c}$ 2530 Single Mixed. 1/2 Oz. 60c; Pkt. 10c 2535 Double Mixed. A tine mixture of all colors.
Sweetly scented.

\section{Candytuft - iberis}

Beds, Borders
Furnual the spring and summer months. Their sweet perfume scents

2549 Giant White Hyacinth Flowered. Differs from the Umbellata type. Flowers tall hyacinth-shaped. 2560 Umbellata All Shades Mixed. Lovely colors! Per. Oz. 75c; Pkt. 10c

\section{Clarkia}

Annual
Very free flowering annual of easy culture producing handsome double flowers on leaty stems and valuable for bedding, for borders and for cutting. 2 to $3 \mathrm{ft}$.

2720 Elegans Double Choice Mixed. Free flower ing double flowers! A gay color mixture. $1 / 4$ Oz. $50 \mathrm{c}$; Pkt. $25 \mathrm{c}$

\section{Celasias - Feathered Cackscomb}

Annual Borders, Backqrounds Full Sun The feathered cockscombs are quite distinct in form and are excellent They may also be cut and dried for winter decoration

2608 Magnifica Mixed. Wide range of lovely colors. 2610 Plumosa Feather Cockscomb Mixed. A 11 briqht shades: $1 / 4$ Oz. 50c; Pkt. $15 \mathrm{c}$ 2618 Cristata Dwarf Mixed. Many showy colors,
immons combs.
Calendula - Winter Marigolds

Annual $\quad$ Borders, Cutting
This showy brilliant flower is a popular choice in California as an This showy brilliant flower is a popular choice in California as an all-winter favorite! You re assured of rich, vivid blooms durina open they bloom freely as early as january and continue into the

2511 Art Shades Mixed. Vivid pastels, picotees, etc.

$1 / 2$ Oz. 35c; Pkt. $25 \mathrm{c}$ 2496 Orange King. Enormous oranqe flowers with rich, dark cen2494 Lemon Queen. Bright yellow. $1 / 2$ Oz. 35c; Pkt. 15c 2504 Masterpiece. Clear orange, contrastinq dark center. Pkt. 15 2488 Yellow Colossal. Extra larqe. loose petaled yellow. Pkt. 25c 2510 Germain's Extra Double Mixed. Choice of many sorts!

\section{Chrysanthemum - Painted Daisy}

Annual Bedding, Cutting Sun Delightful, gay colors fresh from nature's paint-box. Tall showy bushes provide decorative background from Summer till Fall.

2660 Choicest Single Mixed. (Painted Daisy) - In all colors.
2675 Coronarium Double Mixed. $1 / 2$ Oz. 30c: Pkt. $15 c$
ckt. $10 c$

\section{Caleaea - Cathedral Bells}

Climber Hall Shade

2730 Scandens. Rapid climber. Large bell-shaped purple flowers! Thrives in sun or half shade. $1 / 4 \mathrm{Oz}$. 50c; Pkt. $25 \mathrm{c}$

\section{Cinerarias}

Annual Pot Plant, Greenhouse Shade Flowering pot plant and bedding plant of resplendent beauty. It produces gorgeous broad heads of large ter and early spring. Delights in a cool shady location, succeeding well even out doors in Southern Califon, suce

2704 California Super Giants. Enormous flowers. A grand color mixture of light pink to rose, scarlet,
royal blue, crimson.

2700 Choice Hybrids Mixed. Compact free blooming and large flowered. Vigorous arowth and superb

\section{Casmas - for Summer and 7all}

Annual Background, Cutting Sun Graceful, tall, long stemmed flowers and finely cut foliage. Invaluable in the Summer and Autumn garden; the plants are bushy, 5 to 6 feet high and pro.
duce $a$ wealth of excellent cut flowers.

\section{Germains Extra Early Giant}

Extra large flowers for early summer bloom!

2752 Crimson.

2753 Pink.

Pkt. 10c

2754 White.

2755 Mixed.

Pkt. $10 \mathrm{c}$

2761 Orange Flare. Deop orange yellow, early
flowering.

\section{Mammath 9 lowering}

Remarkably tall, broad bushes. Extra large flowers with over-lapping petals. Started early-you have flowers from summer to fall.

2760 Mammoth Flowering Mixed. Oz, 75c: Pkt. $10 \mathrm{c}$ 2772 Sensation Purity. Pure white! Pkt. 15c 2764 Sensation Radiance.

Pkt. 25c

2773 Sensation Mixed. Extra large flowers!

2770 Double Sensation Mixed. $1 / 2$ Oz. 50c; Pkt. 25c son and White fluted flowers. Pink, Rosy Crim-

\section{Columbine - Aquilegia}

Perennial Border Hall Shade The Columbines are most graceful in form and habi and invaluable to correct too stiff or formal plant2197 Long Spurred Blue Shades. Soft blue. Pkt. 25c 2201 Long Spurred Snow Queen. Pure White.

2200 Long Spurred Hybrids. Beautiful large flowers with long spurs. All shades of blue, mauve, yellow, 2195 Single Choice Mixed. Rich in Brilliant shades.

\section{Careapsis}

Perennial Borders, Cutting Sun Showy golden yellow flowers, abundantly produced. They thrive anywhere and bloom the first season. 2751 Mayfield Giant. Jumbo yellow flowers. Per $Y_{4}$ Oz 25e; Pkt. $10 \mathrm{c}$

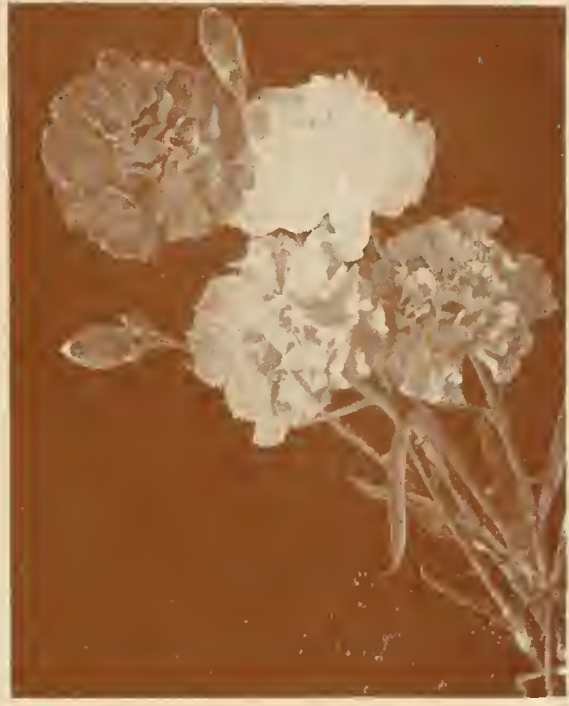

CARNATION CHABAUDS

\section{Improved Giant French Carnations}

Remarkably fine, vigorous strain of French origin. Flow. ers in about five months from seed. It blooms indefi-
nitely! Large, double fragrant flowers in many lovely

2582 Bright Rose. 2585 Scarlet.

2583 Dark Crimson. 2586 Pale Lilac. Pkt. 25c 2584 Flesh Pink. 2587 White. Jeanne 2588 Yellow (Marie Chabaud). $\quad$ Pkt. 25c 2590 Chabaud's Everblooming Giant Flower. Mixed. $1 / 16$ Oz. 60c; Pkt. 25c; 3 for $50 c$ 2570 Marguerite Large Flowered Mixed. Per 1/s Oz. \$1.00; Pkt. $10 \mathrm{c}$

\section{Cyclamen}

Perennial Pot Plant, Greenhouse Halt Sun Charming tuberous perennial plants for the house or sheltered situations in the garden. Foliage rich doep men bloom in about 15 months from seod.

2800 Persicum Giganteum. Finest Giant strain. Gay Colors!

Cypaglassum - Forget-Me-Not Annual Borders, Bedding The dainty blue Forget-Me-Not flowers are

2805 Firmament. Dwarf form of Chinese Forget-Mo Nots in regular forget-me-not blue!

\section{Dahlias}

Perennial Background, Cutting

Bedding Dahlias are very interesting to grow trom seed. This may easily be done in one season, even 2810 Double Giant Flowered Mixed. Saved trom a beautiful collection of cactus and decorative types.

Delphinium - Perennial Larkspur Perennial Background, Cutting Sun The new Pacific Giant Delphiniums are an outstanding contribution to modern floriculture. The tall heavy spikes of huge flowers are majestic in beauty. Pract:-
cally $100 \%$ double in a magnificent range of colors.

\section{Improued English Hylerids}

2830 Perennial Hybrids. Improved double and semi-double. 2829 Improved Wrexham or Hollyhock Strain. A mixture of large, well-shaped double flowers.

\section{Special}

California Native Wild Flower Seed No. 4189. Premium mixture of the loveliest native llowers of California, including California Poppy, Pkt. 15 c; $1 / 2$ oz. 60 c; 1 oz. $\$ 1.20 ; 1 / 4$ lb. $\$ 3.00$

\section{Special}

Everlasting Flower Mixture

No. 4185 Choice Mixed. The most desirable varieties of everlasting or Strawflowers blended

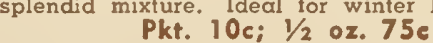


Marning Glaries - and Moonflower Annual Climber The most free flowering and rapid climber in cultiva ion. Ideal for covering fences, pergolas, lath houses. etc. A veritable sheet of color when in bloom. Thrives

3209 Scarlet O'Hara. Velvet red.

Pkt. $15 c$

3201 Clarke's Earliest Heavenly Blue. Sky blue Extra large blooms. 1/4 Oz. 35c: Pkrt. 15 2741 Crimson Rambler Rapid climber. Rich red. Fine for flag colors. with Clarke's Blue and Pearly 3207 Pearly Gates. Satiny white. Pkt. $15 \mathrm{c}$ 2745 Tall Choicest Mixed. Oz. 30c; Pkt. 10c 3210 Imperialis Choicest Mixed. The Handsome showy favorite of all molning glories. $1 / 2$ Oz. 45c; Pkt. $15 \mathrm{c}$ Myasatis - Forget-Me-Not $\begin{array}{cc}\text { Borders } & \text { Shade } \\ \text { Perennial } & \\ \text { Hondsome spring-tlowering perennial flowers. They }\end{array}$ Hondsome spring-tlowering perennial flowers. 3401 Blue Bird. A splendid deep blue shade.

\section{Germain's Nasturtiums}

\section{Annual Border or Trailer}

For color, length of bloom, ease of culture and general usefulness in the flower garden the Nasturtium has no

\section{Double Sweet Scented}

3424 Salmon Gleam. Salmon cerise

3427 Scarlet Gleam. Fieıy red.

3430 Double Gleam Hybrids. Specially s weet 3454 Dwarf Double Gem Mixed.

\section{Giants of Califarnia}

Properly supported, these giants will climb to o height of eight feet or more. They make excellent screens, 3420 Tall Giants of California Mixed. Nemaphila - Baby Blue Eyes Annual Low Borders
3463 Insignis. Sky blue flower, popular.
3428 Orange Gleam. Red Orange flash. 3454 Dita lb. \$1.25: Oz. 40c; Pkt. 15c

3450 Dwarf Mixed. All colors. Oz. 30c; Pkt. 10c

\section{Chaice Marigalds}

Annual Bedding, Cutting

Full Sun

These bright, long-lasting blooms will drench your garden in living sunlight! How gay, cheery, beauty aolds enioy a well-deserved popularity.

\section{Giant Type}

3363 Full Double Orange. An improved rich, deep orange variety with huge, fully double blooms. $\mathrm{Pkt} .25$ 3344 Guinea Gold. Very bright double blooms. 3363 Goldsmith. Incurved Mission type. Gay globu. lar flowers. Bright orange. 3337 All Double Lemon. Giant flowers of deep 3338 All Double Orange. Extra large deep orange A real beauty. 3339 Choice Double African Mixed. Wide Selec 3340 African Mixed. $\quad 312$ Pl. $10 \mathrm{c}$

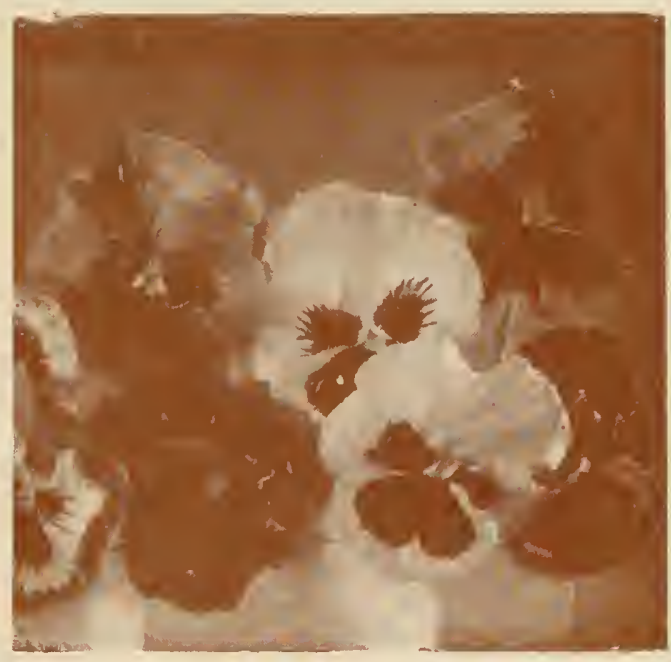

Nemetia - Baby Snapdragon

Annual Edging, Low Borders

Sometimes called the Boby Snapdragon. In o wide 3460 Grandiflora Suttoni Mixed. A bright mixture of attractive tones in red, orange, rose ond blue.

\section{Germain's Giant Pansies - Maxima}

\section{Germains Swiss Giants}

The Swiss Giant Pansies have gained ronown through. out America as well as in Europe. They are of excep. tional size, borne on tall, sturdy stems and very freo
flowering. The biggest, most becutiful blooms of all! 3530 Swiss Giant Blue. $1 / 16$ Oz. \$1.75; Pkt. 50c 3533 Swiss Giant Golden Yellow. A 3534 Swiss Giant Red $1 / 16$ Oz. $\$ 1.75$; Pkt. 50c 3538 1/16 Oz. \$1.75; Pkt. 50c 3538 Super Swiss Giants. Stocky, sturdy, well-de.
veloped plants. Full range and multi-colored blossoms
of great beauty.
$1 / 16$ Oz. $\$ 2.00 ;$ Pkt. 50c

\section{Superle Pandy Mixtures} 3540 Choice Mixed. Medium sized flowers in great
profusion.

3549 Engelmann's Giant Mixed. Very largo, long stemmed flowers. All colors with lovely markings.
$1 / 16$ Oz. $\$ 2.25 ;$ Pkt. 50c 3547 Mastodon Jumbo Mixed. The very latest
creations.
$1 / 16$ Oz. $\$ 2.25 ;$ Pkt. 50c 3543 Mastodon Mixed. Just a Little Bit Better."

\section{Germain's Selected Petunias}

\section{Ballerina}

The F. Hybrid All America Winner for 1952-A soft glowing salmon, $3 \frac{1}{2}$ to 4 inch blooms. Plant dwarf. cellent for pot culture.
Pkt. $\$ 1.00$

\section{Single Bedding} 3593 Pinkie. Very tall, extremely free flowering.
Exquisite rosy-pink. $25 \mathrm{c}$

Pkt. 25c

3609 Radiance. Froe flowering cerise with a gold
throat; Large 2 in. blooms! 3561 Flaming Velvet. Single Flame color. Pkt. $25 \mathrm{c}$ 3577 Rose King.

3576 Crimson Red, Gen. Dodds.

3579 Violet Blue.

3580 Pure White.

$1 / 8$ Oz. 60c: Pkt. 15c

$1 / 8$ Oz. $60 \mathrm{c}$ : Pkt. $15 \mathrm{c}$

$1 / 8$ Oz. $60 \mathrm{c}$; Prt. $15 \mathrm{c}$

3575 Blue Bee. Free flowering. Mid-blue. Pkt. 15c 3599 Select Bedding Mixed. A fine large flower strain in bright, pastel shades. $1 / 4$ Oz. \$1.25: Pkt. $25 \mathrm{c}$ 3600 Good Single Mixed. Vigorous strain. Easilv
grown onywhere. $1 / 4$ Oz. $\$ 1.00 ;$ Prt. $10 \mathrm{c}$

\section{Annual Bedding, Edging}

You could grow an entire garden of petunias alone and never tire of the wide and varied selections of shapes. sizes and bright colors! Hardy, easy to grow-they

\section{Giant Flowered Ruffled}

3560 Dainty Lady. Single fringed creamy yellow for contrast. 3591 Elk's Pride. Pkt. 25c 3597 Scarlet Beauty. Bright red. Showy! Pkt. 25c 3589 Theodosia. Beautiful pink. Large frilled; Yel. low penciled throat! Pkt. 50c 3588 White Beauty Rutfled Dure white. Pkt. 25c 3601 Fluffy Ruffles. $\quad$ Plt. 25c 3598 Ruffled Monsters. Very large, ruffled in all

\section{Dwarf Barders}

Excellent for edging and low ribbon type border. At 3584 Rosy Morn.

3587 Silver Blue.

3581 Snow Queen.

3582 Rose of Heaven

3613 Velvet Crimson.

3574 Dwarf Border Mixed.
Prt. $15 \mathrm{c}$ Plat. 25c Pkt. 15c Plat. 15c Pkt. 25c

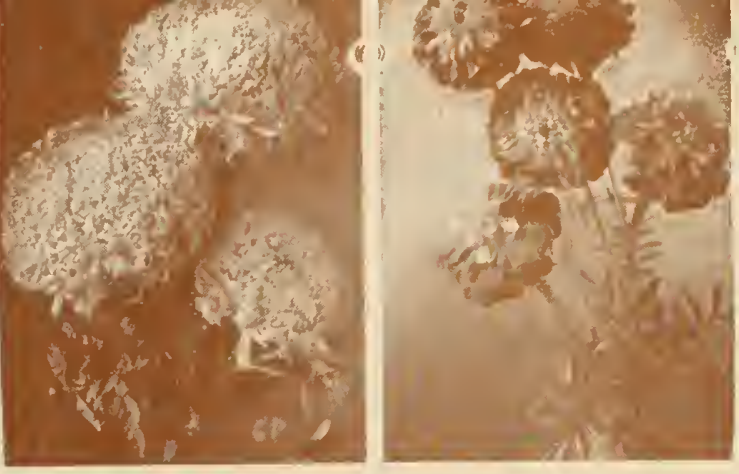

GOLDSMITH

HARMONY

\section{Dwarf - Double French}

3343 Red Head. (Bronze Medal, All America Selec tions 1948) New bedding and border Marigold o dwari French type with orange red flowers deepen
ing 10 bronzy red. 3345 French Dwarf Double Mixed. A now choice assortment of double bloom types. Only 30c; Pkt. $10 \mathrm{c}$

3331 Butterball. An exguisite jewel-like Marigold. ldeal for outlining flower beds and borders. Low growth, long blooming season. Soft yellow lightly
tisped maroon. 50 c; Pkt. $25 \mathrm{C}$

3348 Harmony. Rich bright color. Orange yellow with deep maroon collar! Very double. Frencb
type.

\section{Mignanette - Reseda}

Ansual Edging, Borders, Cutting
3380 Sweet Mignonette. (Reseda Odorata) An old fashioned favorite. Very sweetly scented. An
Oz. 50; Pkt. $10 c$ Mina - Spanish Flag

Annual Climber Su

Becutiful vine. It produces

Nicatiana - Flowering Tobacco

3470 Choice Hybrids. $\begin{gathered}\text { Borders } \\ \text { Large flowering hybrids }\end{gathered}$ Very showy in a variety of colors. $1 / 4$ Oz. 40c; Pkt. 15c

Passiflara - Passion Vine

Perenniol Climbing
3564 Edulis. A woody vine that makes a splendid permanent climber for screening. Interesting laven. er flowers, followed by egg-shaped purple fruit.

\section{Pentstemon - Beard Tongue}

Border
Perennial
Decorative bushy plants, ideal for bed and bordo covered with a luxurious growth of spiked Gloxinic like flowers in brilliont hute
lavender and deep purple.

3569 Hartwegii Grandiflora Mixed. B $\theta$ a morked and spotted flowers. Extra lor $\theta$ a u i if

\section{Phlax - Texan Pride}

Annual Bedding, Cutting
These many-bloom flowers have long been a favorite These many-bloom flowers have long been a favorite
all over the country! You can plant them in almosi all over the country! You can plant them in almost
any type of soil-in almost any location and be assured 3632 Mixed. All colors. Pkt 15 3630 Gigantea Mixed. Extro largo flowers, bright 3633 Dwarf Mixed. Fine for borders. Plt. 25c Shirley Poppie1 - Papaver Annual Bedding Su Well known favorites of the easiest culture. Invaluable grow 2 to 3 foet high producing freely over a long period, lovely, broad petaled flowers of delicate satiny texture and in the most exquisite shades. Sow in fall or early spring, cover very lightly and press firm. 3656 American Legion. New improved variety of
true Flanders Poppy.
$1 / 4$ Oz. 30c; Pkt. 10c

3665 Shirley Single Mixed. 1mproved large flower. ing strain in many beautiful new shades. 0 .z. 60c; Per Pkt. 10c 3685 Double Begonia Flowered Mixed. In many

\section{Giant Iceland Pappies}

Perennial Bedding, Edging
Graceful decorative flowers on long stems, rising from tufts of bright green foliage. Remove seed pods rogu. larly, enjoy season-long blooms!

3698 Gartford Giant Mixed. Bigger flowers! Longer Primula - Primrose

Annual Pots, Shady Borders Shade 3730 Obconica Gigantea. Free flowerina, glowina
colors. 
Ranunculus - Persian Buttercup Annual Borders, Cutting
Large fringed flowers delightully tragrant. Easy to
grow. All giant-sized flowers! 2640 Royal Sweet Sultan Giant Mixed. $1 / 2$ Oz. 60c; Pkt. 150

Polyanthus - Bunch Primrose Perennial Edging, Low Borders Shade 3646 Superb Large Flowered Mixed. Charming primiose type flowers grow in abundance on this
small decorative bush! Bright red, rose and yellow small decorative bush! Bright red, rose and yellow
shades.

\section{Partulaca - Rose-Moss}

Annual Low Borders, Edging

Sun

A favorite free-flowering plant for sunny locations
Mossy fol:age surrounds the dainty primrose like flow

3710 Finest Single Mixed. All shades of rad, rose. yellow, white.

Pkt. $10 \mathrm{c}$

\section{Pyrethrum}

3755 Roseum Single Mixed. Larqe Marquerite. type flowers with fine fern-like foliage! Wide range
of color.

\section{Scabiasas - Mourning Bride or Bedding, Cutting}

Sun

Annual fashioned" flowers. The flowers are large, fully double. sweet scented, very freely produced and splendid fo culting.

3816 Blue Moon. Large lavender blue. Pkt. 15c 3802 Peace. All white. A giant bloom. Pkt. 15c 3805 Azure Fairy. $\quad 1 / 4$ Oz. 35c; Pkt. 15c 3806 Cherry Red. 1/4 Oz. 35c; Pkt. $15 \mathrm{c}$ 3820 Choice Mix. 1/4 Oz. 35c; Pkt. 10c 3826 Giant Hybrid Mixed. Pkt. 25c 3822 Isaac House. Giant hybrid (Perennial). Extra large flowers in shades of blue and lavender. Pkt. $25 \mathrm{c}$

\section{Salpiglassis}

Annual

Borders, Cutting Sun

Sun-loving, velvet-petaled annual $2 \frac{1}{2} \mathrm{ft}$. in height. The 3788 Gloxinia Flowered Mixed. All shades beau ers in gay pastel colors. richly colored, trumpet shaped flowers are produced in tifully veined and shaded. $1 / 8$ Oz. 25c; Pkt. $10 c$

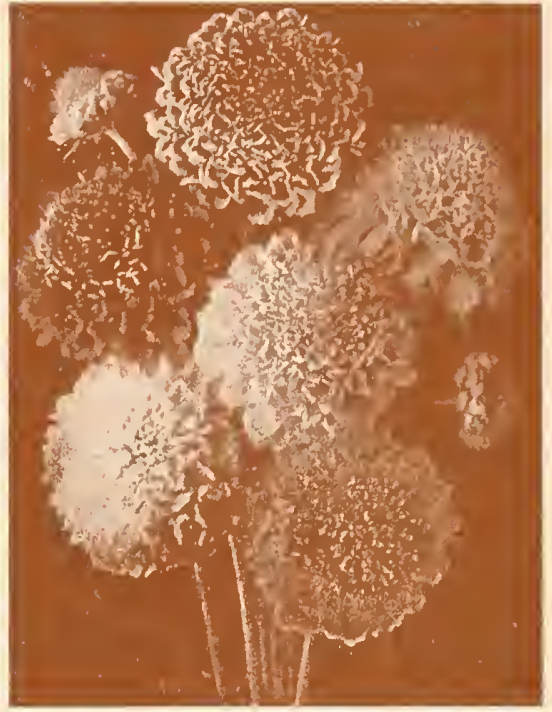

SCABIOSA GIANT HYBRID

\section{Shasta Daisies}

Perennial Borders, Cutting Halt Shade 2680 Alaska. Glistening, broad white petals. Pkt. 15c

\section{Dauble Shasta Daisy}

2687 Giant Double Shasta Daisy. Beautiful, easily grown perennial border plants producing a high percentage of full double Aster-like flowers from seed. Exceptionally vigorous and long stemmed. Delightful cut flowers indoors. In the garden they form large masses of pure white
blooms from July till Autumn.

\section{Rust-Resistant Snapdragons - Antirhinium}

Annual Borders, Culting

Halt Shade

Our Rust-Resistant strains of Giant Snapdragons again make bedang plants though ern California and a dependable source of brilliant 2128 Rust Resistant Majus Grandiflorum Mixed.

2129 University of California Mixed. Oriqinal "Rust-Proof" Strain

\section{Tetra Snapdragan}

The largest flowered of all Snapdragons, many attractively ruffled; stems are stouter, plants stronger, base branching, central spikes $21 / 2$ ft. tall, surrounded by
many lateral spikes. Lovely colors, make a grand many lateral spikes. Lovely colors, make a grand

\section{Germain's Giant Daulele Stacks}

Annual Bedding, Cutting Sun

Stocks are of inestimable value both for garden and home decoration. For brilliancy and diversity of color. unequalled.

\section{Germains Column or Excelsiar}

Each plant prduces one enormous spike, covered with extra large tlowers. No side growth, the vigor of the

924 Column or Excelsior Mixed. Rose, W $\mathrm{h} \mathrm{it}$ it
crimson, lilac.

\section{Early Giant Imperial}

A superb new strain of eally flowering habir Largest sized, double fragrant flowers grow profusely on heavy well furnished spikes. Choose new colors!

3876 Fiery Blood Red.

3881 Dark Blue

3882 Elks Pride Purple.

3886 Deep Rose.

Pkt. 25c

3889 White (Santa Maria).

3883 Golden Rose.

3884 Lavender.

3890 Giant Imperial. Choice mixed.

Pkt. 25c

Pkt. 250

Pkt. 250

Pkt. 25c

Pkt. $25 \mathrm{c}$

Prt. 25c

\section{Rust Resistant Maximum}

2080 Camp Fire. (3 ft. high)

2082 Canary Bird. Canary yellow.

2078 Copper King. Burnished copper.

2084 Loveliness. Soft rose pink.

2086 Paradise Rose. Rose pink.

2089 Rust Proof Maximum. Special

\section{R-R Super Majestic}

A magnificent (About 2 to $2 \frac{11 / 2 \mathrm{ft} \text {. high) }}{\text { new strain with largest sized flowers. }}$ closely placed on strong sturdy stems! Beautiful and stately in your garden, they'll make lovely, long 2127 Super Majestic Mixed.

Pkt. 25c

\section{Large Flawering Ten Weets}

3949 Blood Red.

3945 Bright Rose.

3948 Yellow.

3950 Finest Mixed.

\section{Giant Winter Nice}

All-year-round favorite in California, a standout for greenhouse and home blooming in colder climates.

3910 Giant Winter Nice Mixed. All colors.

\section{Giant Perfection ar Cut-and-}

$$
\text { Came-Again }
$$
garden display!

940 Cut - and - Come - Again Mixed. A grand
assortment of colors. Special

No. 28 Fragrant Flower Garden

An exclusive selection of sweetly scented flowers, the delight of old world gardens for generations.
3 pkts. for $60 \mathrm{c}$; Pkt. 250
3947 Pure White.

Perpetual bloomers, especially valuable for summer
Perennial Beds, Borders, Cutting Sun 3756 Special Strain. Beautiful perennial 12 to 15 inches high, in all shades of red, rose, orange and
yellow. Excelient cut tlower. Ramneya - Matilija Poppy

$\begin{array}{lr}\text { Perennial } & \text { Background } \\ 3774 \text { Coulteri. Large white, yellow center. Pkt. } 200\end{array}$ Glaming Saluias - Flowering Sage Annual Beds, Borders Sun 3792 Splendens (Scarlet Sage). Favorite vivid scar. 3793 Bonfire. Similar to above but compact and early blooming $1 \frac{1}{2} \mathrm{ft}$. tall.

\section{Schizanthus - Butterfly Flower}

Annual Pot, Sheltered Beds Shade 3827 Extra Select Large Flowered Mixed. A wonderful, hardy strain. Well branched, two feet high!
A choice variety of colors. 3830 Choice Mixed. Many fine shades.

\section{Statice - Sea Lavender}

Annual Borders, Strawflowers
Popular for cut or dried bouquets! Sinuata type is an Popular for cut or dried bouquets! Sinuata type is an
annual. Other perennials in $a$ wide selection of gor.

3860 Sinuata Mixed.

Oz. 40c: Pkt. $15 \mathrm{c}$

\section{Sweet William - Dianthus Barbatus}

Perennial Beds, Borders, Cutting Sun Vigorous, free flowering perennial with large showy flower heads in bright attractive colors abundantly 3970 Large Single Mixed.

3975 Extra Large Double Mixed. $\quad$ Pkt. 15c

\section{Texas Blue Bannet}

3981 Lupinus Texanus.

Pkt. $10 c$

Thunbergia - Black-Eyed Susan

3984 Alata Mixed. Climber Sun 3984 Alata Mixed. Orange, buff and white. A
daisy-like climber!

\section{Germain's Verbenas - vervain}

Annual Low Borders, Bedding Sun 4017 Beauty of Oxford. Giant-Rose. Pkt. 25 4012 Royale. Royal Blue, yellow eye. Pkt. 250 4005 Lavender Glory. Lavender, white eye. Pkt. $25 \mathrm{c}$ 4001 Lucifer. Brilliant self scarlet. Pkt. 25c 4004 Hybrida Gigantea Mixed. 1/8 Oz. 75c; Pkt. 25c 4006 Pink. Pkt. 15c 4009 White. Pkt. 15c 4007 Purple. Pkt. 15c 4010 Mixed. Pkt. 15c 4008 Scarlet. Pkt. $15 c$

\section{Vinca - Madagascar Periwinkle}

Perennial Borders, Bedding Sun The Madagascar Periwinkle is an excellent and con stantly blooming "perennial, with shiny leaves and 4020 Choice Mixed.

\section{Virginia Stack}

Annual Edging, Rockeries 4045 Mixed.

Oz. \$1.15; Pkt. 10c

\section{Vialas - Tufted Pansy}

Annual Edging, Low Borders Shade There are few bedding plants so dependable, so color ful, so persistent in blooming over a long period of such profusion that the beds are a sheet of bloom through the entire season.

4031 Arkwright Ruby. Ruby.

4024 Chantreyland. True Apricot.

4022 Blue Perfection.

4028 White Perfection.

4026 Yellow Queen.

4038 Heavenly Blue.

Pkt. $50 \mathrm{c}$

flowering Grandiflora Mixed. New P a n s y 4030 Tufted Pansies Mixed. $1 / 16$ Oz. 90c; Pkt. $15 \mathrm{c}$ 4044 Johnny Jump-Up. Tiny flowers marked with purple, yellow and white. Tht. 25c

\section{Wall Flawer}

Annual Bedding, Cutting Sun The velvety petals of this old time favorite are rich in Ches of bronze, copper and butt.

Choice Single Mixed. 4062 Double Flowering Extra Select. Large spikes
Prt. $25 \mathrm{c}$ 


\section{GERMAIN'S NEW MIRACLE ZINNIA Lucky Strike}

Mllustrated in Cor "Lucky Strike" Zinnias - by Superinten dents of major U. S. Parks, under all sectional growing conditions - this newest creation by Germain's is acclaimed THE FINEST GIANT ZINNIA OF ALL TIME! NEWEST COLOR SHADES YOU HAVE EVER SEEN! Exotic two and hree tone harmonies vibrant crimsons, yellows, with bi-colors and subtle overtones...thrilling shades of lilac, violet, lavender... vivid, brilliant orange and new exciting colors and shades you've never seen before! The huge flowers, on extra long stems, have a UNIFORM strain of truly inlormal type. Vigorous plants grow $3 \mathrm{ft}$. tall and bloom profusely entire season. EASY TO GROW. ANOTHER AMAZING ORIGINATION bY GERMAIN'S-creators of famed All America Rose Winners. "LUCKY STRIKE" ZINNIA is the result of 20 years of scientific plant breeding in California where hundreds of outstanding new flowers have been developed.

SPECIAL OFFER! Be the lirst in your neighborhood to proudly display this New Aristocrat of all Zinnias: "Lucky trike, in your garden.

4129 Lucky Strike Full trial Packet (75 Seeds)....................25c Special Jumbo Size (6" $\left.\times 9^{\prime \prime}\right)$ Package (500 seeds) for only $\$ 1.00$

\section{Dahlia-Flowered ZINNIAS}

Deep centered Dahlia-like flowers of huge size. A favorite strain branched and grow $2 \frac{1}{2}$ to 3 feet high. Our named varieties are true to color and our Gold Medal Mixture offers a beautiful range of the finest and most popular shades.

4087 Canary Bird. Primrose yellow.

4088 Crimson Monarch. Best Crimson.

4089 Dream. Deep lavender or purple.

4091 Exquisite. Rose with darker center.

4092 Golden State. Rich oranqe vellow.

4097 Polar Bear. White.

409.8 Scarlet Flame. Vivid scarlet.

4 101 Gold Medal Dahlia-Flowered Mixed.

of many becutiful colo

\section{Super Giant Binnias}

186 - Huge flowers often $51 / 2$ inches across in a wonof the largest and most beautiful Zinnias in existence. The many wo tone combinations and unusual shades of cream, buff, apricot, salmon, rose and orange, as well as the diversity of blends of Zinnias for the garden, for cutting and exhibition.

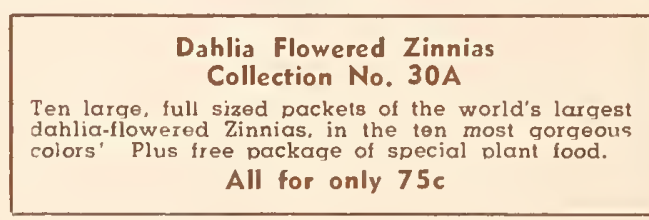

\section{New Crawn O'Gold Binnias}

4183 Crown $O^{\prime}$ Gold Improved Pastel Tints. Very larce and showy blooms 5 inches across. Vastly formed flowers in rich pastel shades, each petal over. laid at the base with doep aolden yellow. Gives each flower a distinct bicolor appearance which is most artistic and beautiful. Superb cut flowers. 4160 Haageana (Mexican Hybrids). Small, ve $r y$

\section{Nem Gantasy Binnias}

Fantasy Zinnias are unlike anv other type of Zinnia yrown. The entirely novel, shaqqy appearance presented by their fluted, quilled and informally curled petals is a pleasina surprise and offers a flower displays.

4151 Fantasy Mixed.
"FAR SUPERIOR TO ANY ZINNIA EVER GROWN", Say Leadinq Park Superintendents few of the written comments: Far superior to other Zinnias we have
grown. Unusually large flowering. The range of colors was outstanding.

Georqe A. Mallett.

Supt. of Parks. Bridqeport, Conn.

I believe them to be much superior. have seen.

Russell Kelley,
Supt. of Parks, Jacksonville, Illinois Best we have had for color. Outstand ing color variations.

Board of Park Commissioners.

Board of Park Com

Lucky Strike Zinnias were larger than any we have had previously. The thing that impressed me most in these Zinnias was the extremely clear colors.

Supt. of Parks, Saginaw, Mich.

Much larger and showier. Very much impressed by the new pastel colors and bicolor flowers. So was the public.

Supt. Audubon Park, New Orleans, La Far superior. Excellent ranqe of color and color combinations.

L. C. Palmer,
Supt. of Parks, Grandville, Mich. They are the finest I have ever qrown

Glenn W. Garwood

Supt. of Parks, South Pasadena, Cal. Superior 10 any I have grown. More brilliant flowers. I think you have a proud to grow and display.

Supt. of Parks, Williamsburg, Va.

Supl. lace This is the best combing pasiels that I have ever grown. The bril a mauve pink especially impressed me. I have not seen anvthina like them before.

C. L. Mcllwaine, Superior to any we have seen of planted. Deeper color and larger foliage. more so than any other.

Supt. of Parks, Richmond, California. Bloomed two to three weeks earlie Bloomed two to three weeks earlier llowers were magnificent.

Charles E. Nelson, Lucky Strike Zinnias are superior to an giant Zinnias 1 have had. It has been oulstanding in viqor, structure and color.

Supt. of Parks, Akron, Ohio.

The size of the blooms was as much as 7 inches across. Personally 1 think hat the colors in your Lucky Strike are y outstanding,

Supt, of Parks, Huron, So. Dakola.

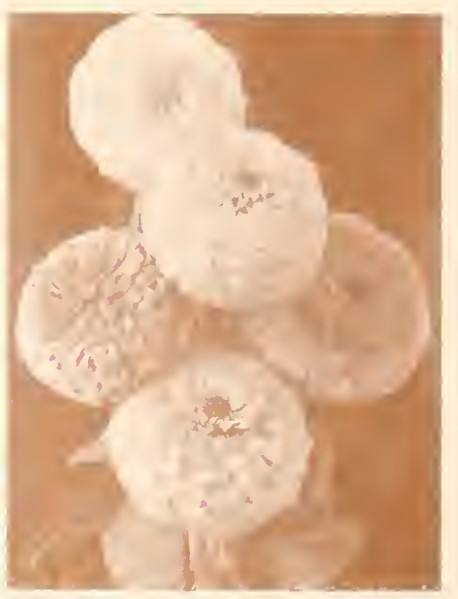

Germains Lilliput, Baley ar Pampan Binnias

Small pompon Zinnias invaluable for tinq and qay qarden borders.

4143 Golden Gem. Golden oranae.

4145 Scarlet Gem. Brlqht red. Pkt. 15c

4146 White Gem. Pink white. Pkt. 15

4140 Rosebud. New rose pink. Pkt. 15c

4149 Lavender Gem. Pleasina laven.

4141 Canary, Vivid canarv vellow

4148 Salmon Rose. A lovelv shade.

4150 Pompon or Lilliput Mixed.

4135 Tom Thumb Mixed. 3 for 60

135 Tom Thumb Mixed. Dwart.
inches hiah. Small double flowers.

\section{Germains Califarnic Giants}

Giants in size. Heavily branched, bearina 4175 Daffodil. Canarv Yellow. Pkt. Isc 4162 Orange King. Burnt Oranqe. 15 4166 Rose Queen. Rose oink, deep rose 4174 Violet Queen. Lavender Violet. 4167 Scarlet Gem. Glowing skt. 4164 Purity. Pure while Pkt. $15 \mathrm{c}$ 4177 Miss Willmott. Favortle solt pink 4168 California Giant. Named varie ties mixed. Price 1/2 oz. 70c: Pkt. $25 \mathrm{c}$. 4170 Choice Mixed. Plt. $10 \mathrm{c}$

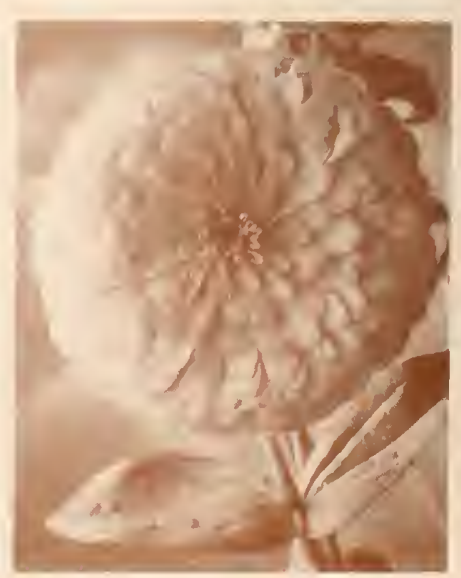




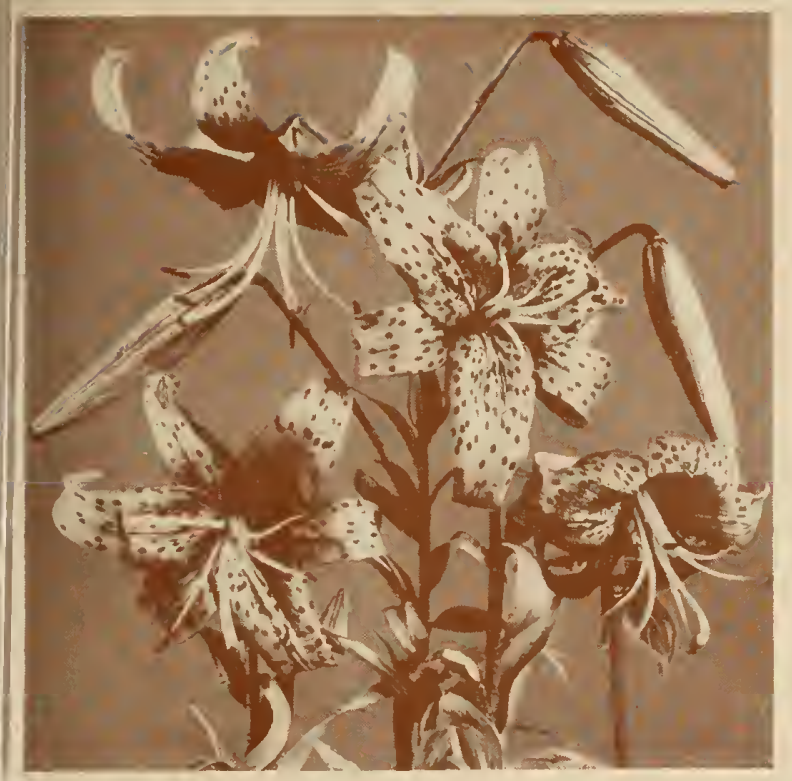

TIGRINUM SPLENDENS

\section{Acidenthera}

"Sweet Scented Gladialud"

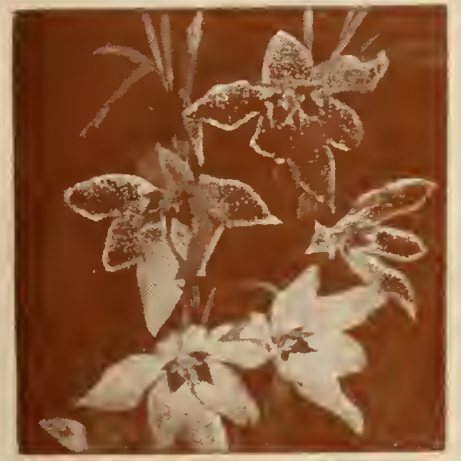

5020 Acidenthera Murielae

A vigorous growing Gladiolus-like flower. highly scented. They bloom late in the are white with a are white with
brilliant purple marking in the con ter. The stems grow about 2 to $21 / 4$ feet tall and the flowers

6 bulbs for $89 \mathrm{c}$ 12 for $\$ 1.69$; 25 for $\$ 3.29$.

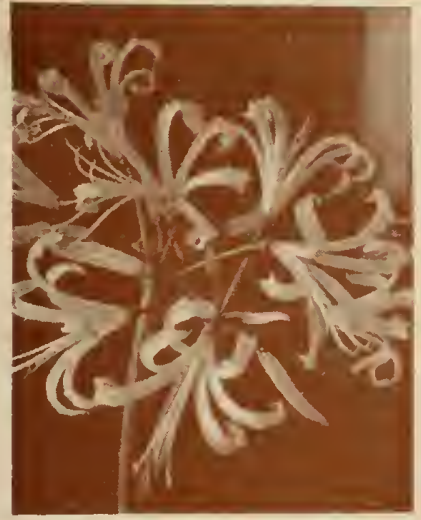

\section{LYCORIS}

5445 Radiata. A coral red Spide Lily. If planted in late Spring wil bloom the same year. Is not hardy. should be lifted during the winter An excellent pot plant.

Price: 3 for 69c; 6 for $\$ 1.29$

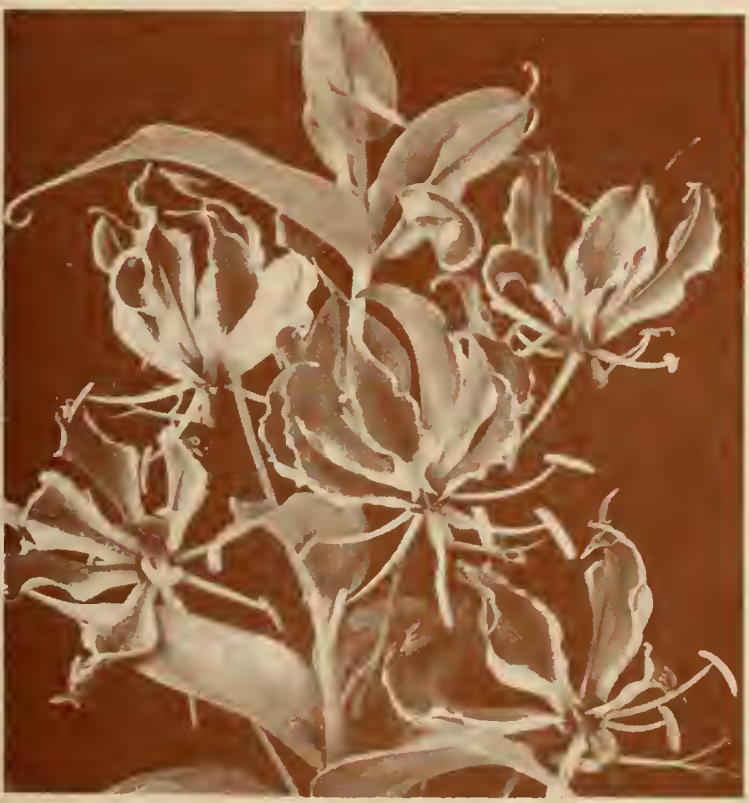

GLORIOSA

\section{Hardy Garden LILIES}

Lilies are easy to arow ond will do well in tull sun as well as in shady locations. While they like plenty of moisture, be sure adequate drainaqe. Lilies do not like heavy fertilizing. heither do they like to have their root svstenis disturbed during shrubbery.

5370 Sunset Lily. (Pardalinum Giqanteum.) $\bar{A}$ brilliant Lily Easy to grow. Height about 5 feet. Five to six flowers on

5371 Centifolium A ma showy.

5372 Tigrinum Splendens. The finest and most robust ot the Tiger Lilies. Large shapely flowers of orange-red spotted black 59c each: 3 for \$1.59; 6 for \$3.09.

5373 COLLECTION: 2 each of above 3 Lilies

$$
6 \text { in all for only } \$ 2.89 \text {. }
$$

5368 The New Bellingham Hybrids. Robust plants qrowing 4 to 5 teet high. Flowers grow in pyramidal clusters of 20 to 30 blooms. The blooms are shaped like a Turk's Cap. The colors range from orance yellow. $\$ 1.50$ each; 3 for $\$ 4.25 ; 6$ for $\$ 8.25$.

\section{Papular Hame Garden Lilies}

$\$ 375$ Henryi. A Stems, bearin 20 flowers of glowing cinnabar red spotted glossy black.

5376 Formosanum. Long trumpet-like, shaped flowers o

5377 Regale. A truly hardy Lily Sturdy stems 4 to 6 . of tlower flushed yellow. Outside the petals are streaked brown at the ribs. $\AA$ flower of great beauty.

5378 Croft. A relative of the Giganteum. A true Easter Lily. Good for indoors as well as outdoor culture.

5379 Coral Lily. A charming little early flowering Lily. Coral red waxy flowers. Likes cool shady places. Good for borders or rock gardens.

5380 Golden Glearm. Another beautiful little Lily. More robust than the All Above-49c each: 3 for $\$ 1.39 ; 6$ for $\$ 2.69$.

5382 COLLECTION OF POPULAR HOME GARDEN LILIES. One bulb each of the above. 6 bulbs in all for $\$ 2.25$.

BARGAIN OFFER No. 5385

"GARDEN OF LILIES". Special Offer 10 bulbs A magnificent labeled. $\$ 3.00$.

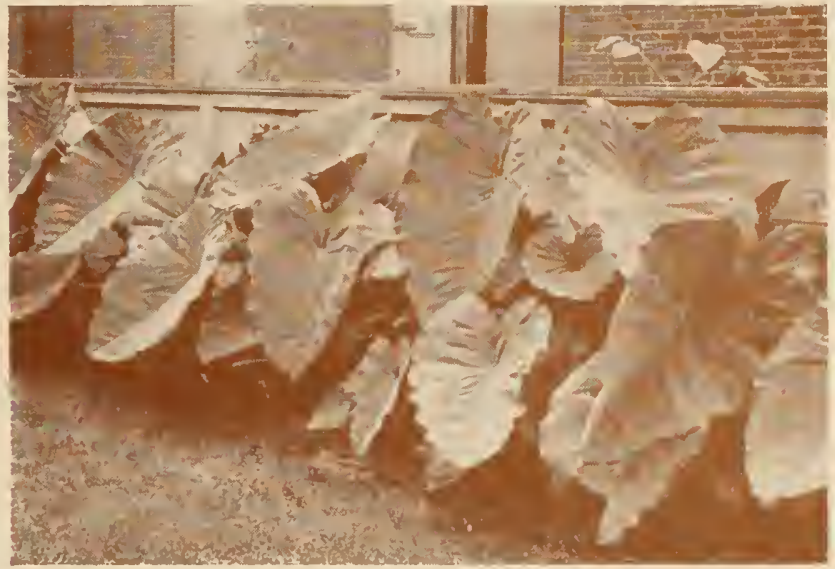

Achimenes

\section{ISMENE}

5440 lsmene Calathina (Per vian Daffodil) One of the best Large summer flowering bulbs tragrant flowers Multiplies rapidly and

Price: 1 for $69 \mathrm{c}$ : 3 for $\$ 1.89$ 6 for $\$ 3.69$.

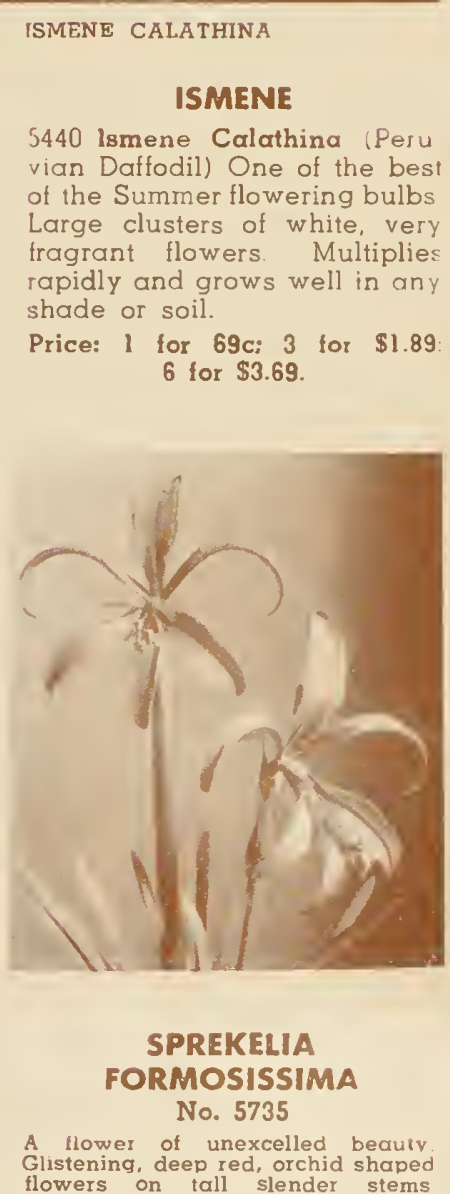

SPREKELIA FORMOSISSIMA

No. 5735

Gistening, deep red, orchid shape

lowers on tall slender stems

$49 \mathrm{c}$ each; 3 for $\$ 1.39$; 6 for \$2.69; 12 for $\$ 5.29$

CALADIUM

5180 Elephant's Ear the leaves of immense size of four

First size: $50 \mathrm{c}$ each; 3 for $\$ 1.39$ 6 for $\$ 2.59$
A lovely plant for the house or window boxes. Thrives only in shady spots and responds perfectly to treatment given Tuberous Begonias The variety we are offering here has great cascades of flowers of a Pansy-like form. Excellent for pots or hanging baskets.

3 bulbs for 59c; 6 for \$1.09. 12 for $\$ 2.09$

\section{GLORIOSA}

No. 5222

\section{A charming importation}

Atrica Otten called the "Climbing

Lily " Blooms profusely The tlow ers, which resemble the Tiger Lily are yellow and orange, spotted deep crimson. A good pot plant. When planted outdoors place against pillar or trellis as it is inclined climb and often will reach a heigh of three or four feet.

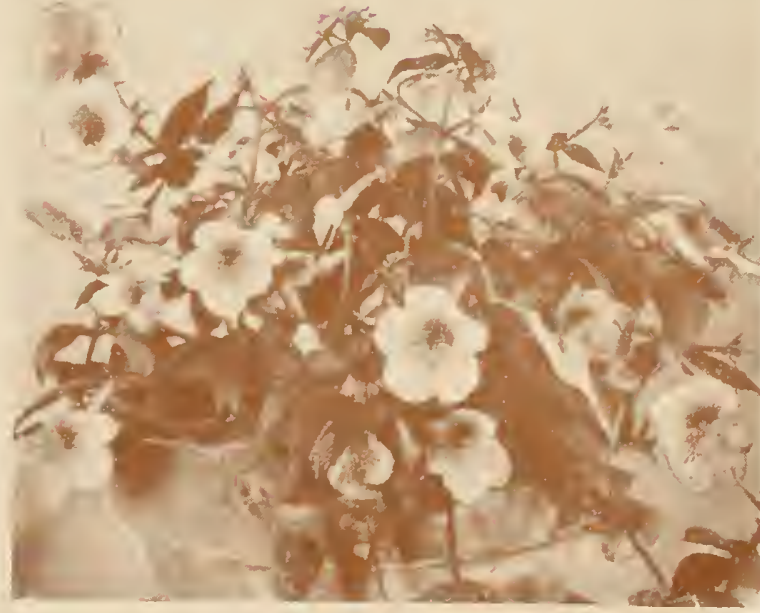
Each \$1.50; 3 for $\$ 4.25$ 


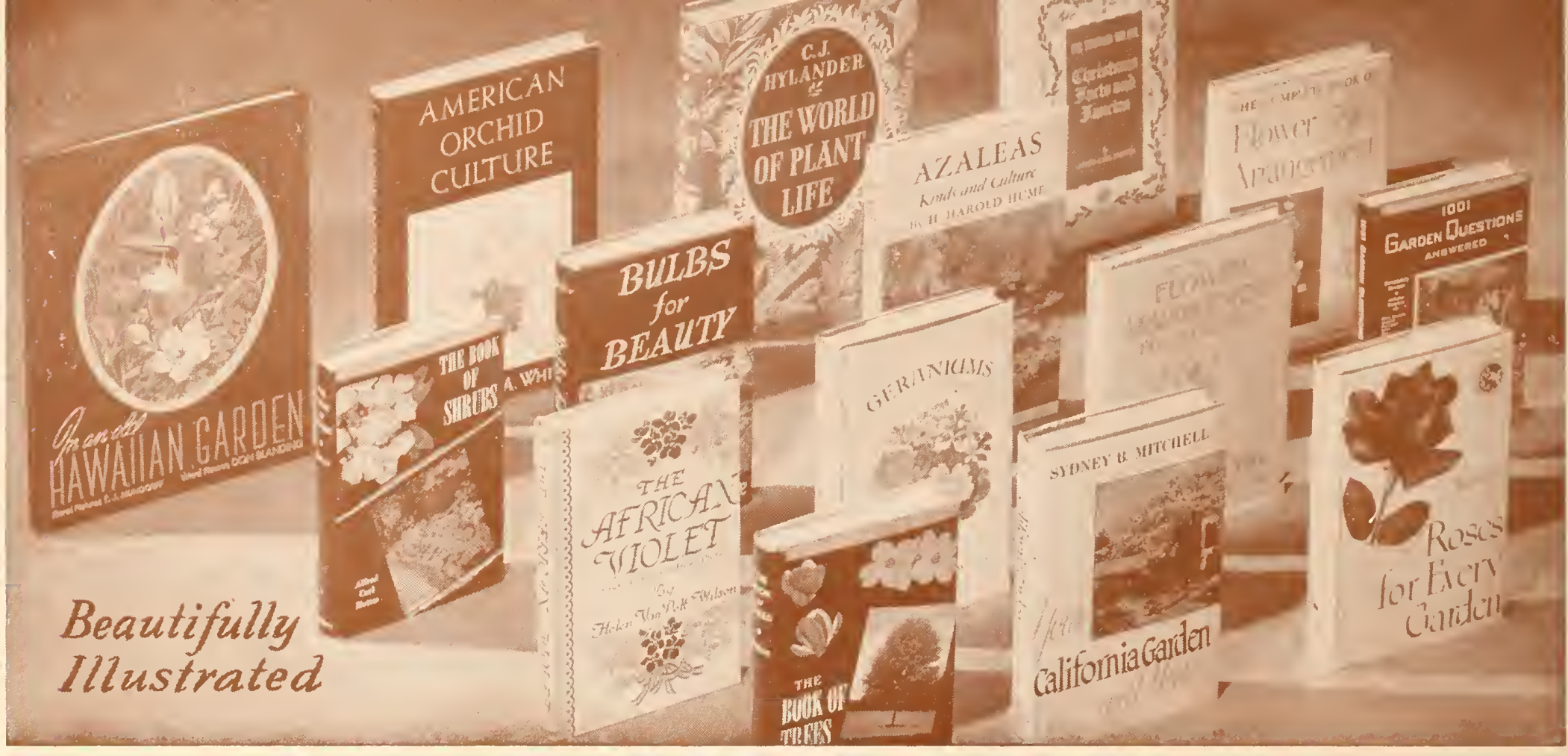

\section{Madern Harticultural Baoks}

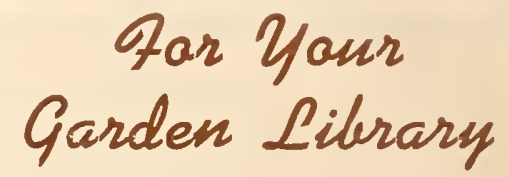

\section{SUNSET FLOWER GARDEN BOOK}

The prime purpose of this book is to show you the how of qardenina. It embraces every anqle of aarden cyclopedia for western qardeners.

SUNSET VISUAL GARDEN MANUAL

Sunset's New Garden Manual shows you how

$\$ 2.00$ 32E02

$\$ 1.50$

SUNSET BARBECUE BOOK

Brings you un to the minute on the barbecue and barbecue parties. Complcte plans, materials and con-
struction, furniture, etc. ALL ABOUT HOUSE PLANTS-By Montague Free Gives complete information on what to arow and how. praes of full-color illustrations.
$32 \mathrm{EO} 4$

$\$ 3.50$ FLOWER ARRANGEMENT WITH COLOR - BY Rockwell. Considered the most comprehensive volume on flower arranaement ever published. A direct, lucid,
step-by-step quide to makina good floral displays for the home 32 E05

$\$ 4.95$

GARDEN BULBS IN COLOR-By McFarland.

The most excitina book about bulbs ever published!
275 color nlates! $32 \mathrm{EO6}$

$\$ 3.95$

GARDEN FLOWERS IN COLOR-BY D. J. Foley. 400 photoqraphs in this "best seller." Formerly $\$ 3.75$. $32 \mathrm{E} 07$

$\$ 2.95$

STANDARD CYCLOPEDIA OF HORTICULTUREBy L. H. Bailey. In 3 volumes, the most important

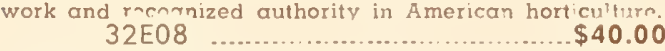
ROSES OF THE WORLD-By J. Horace McFarland Maqnificently illustrated with page after paqe of full
color illustrations picturing novelties and old time favorites in Roses
32 EO9

TUBEROUS BEGONIAS - By Worth Brown.

A complete quide for amateur and specialist-qives

HORTUS SECOND-By L. H. Bailey

$\$ 2.75$

PACIFIC COAST TREES-BY McMinn.

$\$ 8.50$

The complete where, when and how to use annual

CAMELLIAS-By G. G. Gerbing.

$\$ 4.00$

Beautifullv exccuted with 108 pictures in natural colors.
$32 \mathrm{E} 12$

AMERICAN ORCHID CULTURE-BY E. A. White.

Orchids for the use of American growers, both com$32 \mathrm{E} 13$
THE AFRICAN VIOLET-Saintpaulia

By Helen Van Pelt Wilson. Tells how to promote continuous bloom. Discusses all aspects of culturelocation, waiering. temperature, mealybua and mite control-and aives a new classification based on the color sequence of freshly athered blossoms. Describes $32 \mathrm{E} \mid 4$

$\$ 2.95$

HOW TO INCREASE PLANTS-By Hottes.

Tells how to multiply desirable plants by seeds, cut-
tinqs, divisions, araftina, etc. $32 \mathrm{E} 15$

$\$ 3.00$

ENCYCLOPEDIA OF GARDENING-By Taylor. Complete Garden Dictionary. Compiled with vision $32 E 16$..................................\$5.00 HOME ORCHID GROWING-By R. T. Northern. Every major species fully treated, methods of arowina and ways to make it a profitable hobby.
$32 E 17$ AMERICAN WILD FLOWERS-By H. N. Moldenke Describes and illustrates American Wild Flowers from 32E18

$\$ 6.95$

PLANT DISEASE-By Cynthia Westcott.

Designed to afford quick, accurate detection of dis cases caused by baciena, lunal, viruses, mutrien def
ciencies.

THE BUG BOOK-By Cynthia Westcott

Scient fically accurate and presents subec
that any layman can follow. 590 paqes.

$\$ 7.50$

32E20 ........ \$4.95

ROSES ILLUSTRATED-Portland Rose Society.

159 illustrations make visual "how to do it" quide in
Rose qrowina. 197 Rose pictures, 71 in color.

CAMELLIAS ILLUSTRATED - Portland Camellia

Society. Complete and practical articles on all

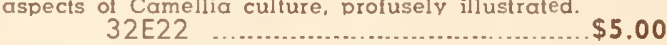
CAMELLIAS AND COMMON SENSE-BY Claude Chidamim. A new common sense approach to Camellia culture, propaqation, landscaping, cutting, etc.
$32 E 23$......................................\$3.50 HOLLAND'S HANDBOOK FOR SOUTHERN GARDENERS-By B. A. Davis. Covers the field of gar

$$
32 \mathrm{E} 24
$$

$\$ 3.00$

HOW TO BUILD FENCES AND GATES

$$
\text { 32E25 }
$$

$\$ 1.50$

IN AN OLD HAWAIIAN GARDEN-BY T. J. Mundorf. Word Pictures by Don Blandinq-a lovely, beautiiully illustrated volume to treasure in the home. the alories of Hawaii's exotic flora.
CHRISTMAS FACTS AND FANCIES-By Alfred Carl Hottes. Most complete and fascinatina book about Christmas and its celebration. Gives new ideas for home fun, decorations and foods. Tells of customs of earlier days and distant lands. A source of inspiration $32 \mathrm{E} 27$

$\$ 3.25$ THE WORLD OF PLANT LIFE-By C. J. Hylander Classifies and discusses virtually every common type of plant now extant in this country. A detailed and seaweed on the ocean floor mosses plant forms from flowers and trees of our American fields, forests and $32 E 28$

$\$ 4.50$

AZALEAS-KINDS AND CULTURE - By H. Harold Huml. Well desiqned Azalea plantinqs immed iately lift a qarden out of the commonplace. This volume, by an authority, presents up-to-date informaselect. etc. Profusely illustrated in color.

$\$ 4.25$

THE BOOK OF SHRUBS-By Alfred Carl Hottes. A mine of information on evervthing relating to shrubs as qrown in every part of the county-Complete non prune and spray.

$32 \mathrm{E} 30$

$\$ 4.25$

THE BOOK OF TREES-By Alfred Carl Hottes. Every worth while tree is described with notes as a culture, propaqation, pruninq, etc., plus a multitude of history, favorite tree poems, etc.

$\$ 4.25$

1001 GARDEN QUESTIONS ANSWERED-BY Alfred Carl Hottes. If you are an amateur gardener you may not think there are 1001 questions that might arise about your small home aarden-yet here they are Iact an $32 \mathrm{E} 32$

$\$ 3.75$

ROSES FOR EVERY GARDEN-By Dr. R. C. Allen. Whether you arow five roses or five hundred, wherever you live, this is vour complete quide to success and tion, preparing the soil, caring for roses, how to propaqate and hybridize, protection, exhibiting and arranq

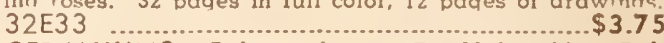
GERANIUMS-Pelargoniums-By Helen Van Pelt Wilson. If geraniums aren't your hobby when you begin this aay book, they will be when you finish formation on collecting and qrowing sinqle, double. and Martha Washington. 7 color plates; 15 black and white photoqraphs: 23 paqes of drawings. 32 E3 4 ............................................. $\$ 3.25$ FLOWER ARRANGEMENT FOR EVERYONE-BY Dorothy Biddle \& Dorothea Blom. Makina arranae. ments for the home, the church, and the flower show is clearly explained; also corsade desianina. fring a dozen lus, and usinq containers-11 compositions shown for 1 vase. "One of the best books" savs Book of the month Club News. 80 photoqraphs. 

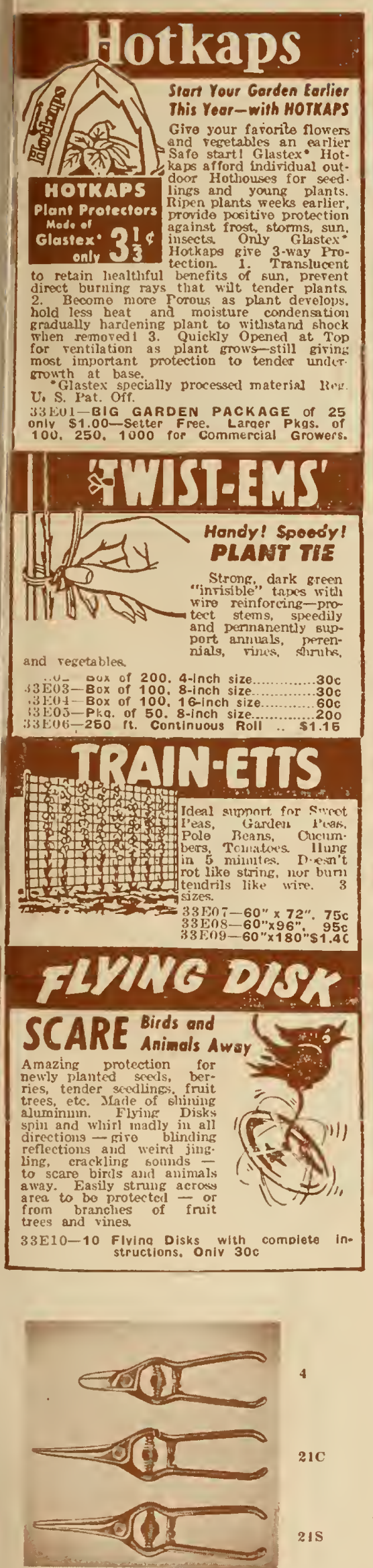

CORONA GARDEN PRUNER NO. 4 The Corona Garden Pruner is a com panion tool to the Corona Calkins Pruner. flower harvesting and for general alleround work in the garde general all shop or wherever llight shears are used. the Garden Pruner is unsurpassed. GRAPE SHEAR

Espectally designed for the harvesting of this shear has found man and fields, where it is used for varled pruning.

33E12-Grape Shear-No, 21S

wE tralght blades s......... \$2.40

with Grape Shear-No. 21C

.82 .06

\section{Garden Accessaries, Insecticides}

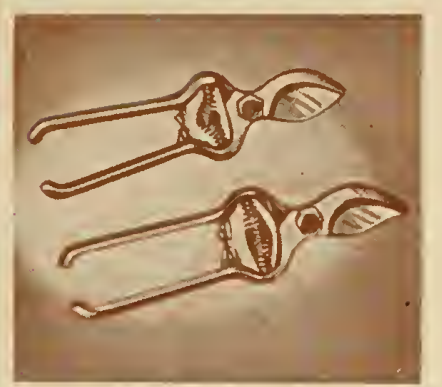

CALKINS PRUNER NO. 8

Calkins No. 8, the orlginal is smaller than the "Pro", but of the same high only seven ounces, but does the heaviest work.

\section{CALKINS "PRO" PRUNER NO. 800}

Calkins Pruners have attalned an en viable reputation in California's greatest the professional model and is used ho fine workmen who demand the best. 33E15 -

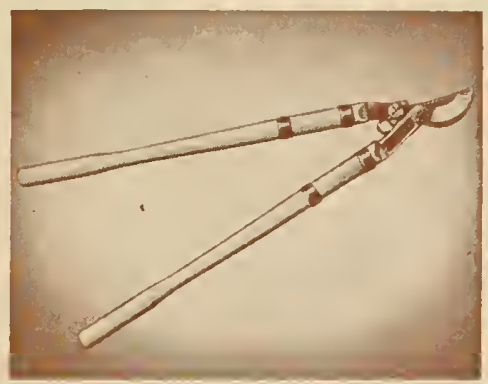

HAWLEY PRUNERS

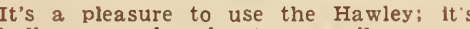
hollow ground and cuts so easily.
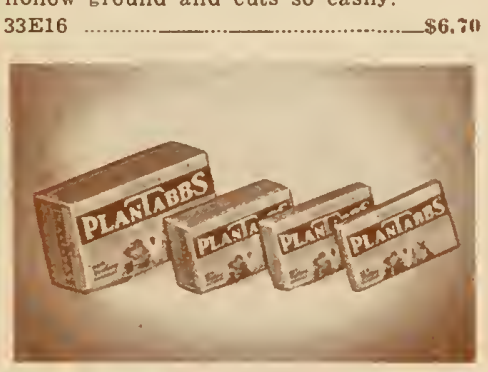

FULTON'S PLANTABBS

Safe, economical, odorless. An 1deal complete plantfood for garden and house 33E17 Plantabbs, 30 Tabs 33E18 Plantabbs, i5 Tabs

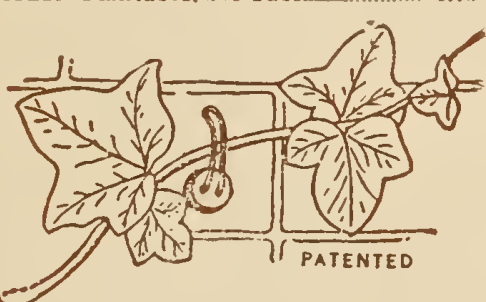

WAYWARD VINE GUIDES

These ingenious supports are easily a
tached to walls, fences, etc. and hold without nailing, to brick, stucco, cement or wood. Support 1vy, roses, vines. Order red for brick, gray for stone. White for

33E20 Box of 25 (incl. cement) .... \$1.15

\section{VILLAGE BLACKSMITH} GRASNIP

For trimming grass, small plants. edg. ings, etc. Tool steel blades polished on
both sides. 33E21

\section{PLASTIC WATERING POT} Very light and very colorful. Holds ap proximately 1 at. of water. Ideal fn: Indoor plants and window garden. Green.
Cholce of colors, maroon, bronze or green. 33 E22 …_.............................. 81.30

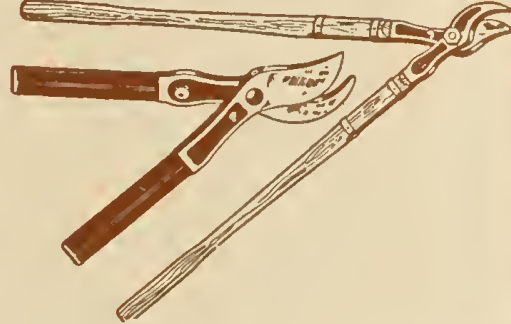

JOOST TREE AND VINE PRUNERS Blades and hooks are made from our own analysis - finest quality, electric fur pered for maximum strength and wear. Both blades and hooks are surface ground to a tolerance of less than twothousandths of an inch, insuring clean cutting and

33E23 "Artisan" Model No. 24A 18 inch handle .................. Each \$6.30 3 E24 "Brand" Model No. 24B,
18 inch handle ........-..-Each $\$ 5.80$

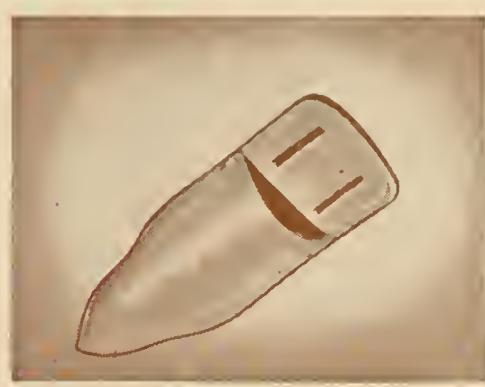

CORONA LEATHER SCABBARD Made of genuine hoavy collar leathe $33 \mathrm{E} 25$ - - . -

WEEDER AND ASPARAGUS KNIFE No. $25 \mathrm{~N}$

$$
\text { Not Illustrated }
$$

Has a 5 inch length handle of black satin finish. Its overall length is 14 inches. A combin 33 E35

\section{BLOOMLIFE}

Feeds and prolongs the life of cut flow ers and helps to retain color and fragrance.

$33 \mathrm{E} 26$

MILLER'S

GARDEN COMPOST MAKER Save weeds, leaves, garden rubbish and convert them into Organic Humus Fertilizer. Remember organic Fertilizer that bacterias, yeasts, molds, etc.. feed upon and give "life" by helping to liberate and make available the
elements contained in the soil. $33 \mathrm{E} 28 \quad 5$ lus. \$1.30; 33E:29 25 lUS $\$$.

\section{FLORALIERS}

Revolutionary new flower holder that makes home flower arrangements look as and it's fun! A lovely gift or party prize. 33E30 $3 . . . . . . . .2$ Each \$1.45

WICK LAWN EDGER The only Edger with self- adjusting cutting knife. Follows contour of the greater ease and faster operation. $33 \mathrm{E} 31$

THREE PIECE HAND TOOL SET Stamped from heavy gauge steel, metal cap on handles, painted finish, trowel, 33532 set of all three onl

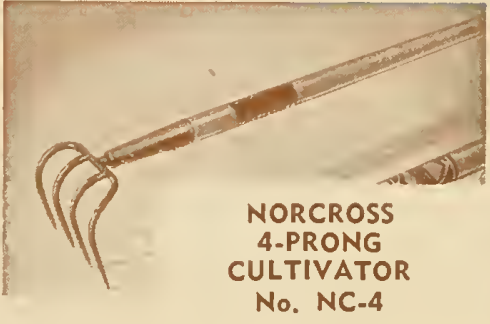

Forged from one piece high carbon steel. prongs, correctly curved and tempered. HANDLE: four and one-third foot, sely sanded and lacquered clear. 33E33

NORCROSS CULTIVATOR No. $33 \mathrm{~N}$

HANDLE: $4 \mathrm{ft}$. selected hardwood. sanded smooth, clear lacquer finlsh.
PRONGS: High carbon square steel, malPRONGS: High carbon square steel, malSHOVELS: Forged from one piece, heavy reinforcing rib on back. uniformly spaced and scour freely.

33E34

$\$ 2.25$

HAYES FERTL-RAIN APPLICATOR

Attaches to garden hose. Proportions while watering.

33E37

\section{GERMAIN'S SOIL-AIDS}

MICHIGAN PEAT
For Luxuriant Roses and Shrubs.

Mix $1 / 2$ peat with $2 / 3$ soil when planting. During hot weather, mulch with 1"
peat to keep moist. "Winter, mulch with

For Azaclas, Rhododendrons, Trees, These like "peaty" soils. Mix 1/2 peat with $1 / 2$ soil around roots when planting. For established evergreens, use year $33 \mathrm{E} 37100$ Cubic inches

SPONGE-ROK

Air-Conditions Your Soil

Csed by Professional Nurserymen an Soil Conditioning for Cuttings, Seed Beds, Flower Beds, Lawns. Potted Plants. Dish Gardens, Growing Bulbs in
Storing Bulbs, All-Season Mulch. $33 E 38100$ Cubic inches.
$33 E 39200$ Cubic inches... $.39 c$

ATKINS \& DURBROW GARDEN PEAT MOSS

the needs of the small user-the garden lover who can use only limited quantities

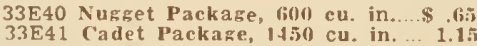

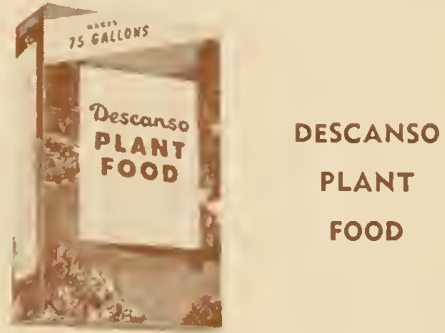

This remarkable new fertllizer is hlghIy concentrated and in powdered form. It dissolves quickly in water, and de-
spite its strength. will not burn follage, when used as directed. It is 1deal for zardens, lawns, shrubs and indoor plants 2 level teaspoonfuls make 1 gallon of

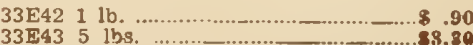




\section{GARDEN ACCESSORIES}

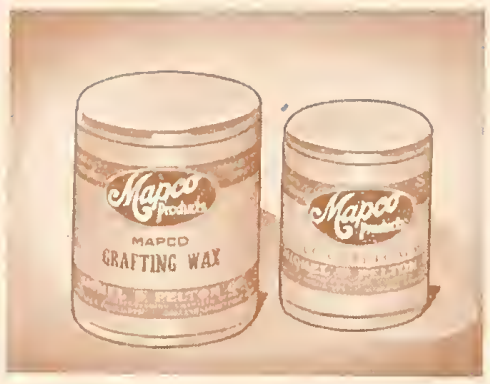

GRAFTING WAX

Use in budding and grafting.

$\begin{array}{ll}34 \mathrm{E} 25 & 1 / 4 \mathrm{lb} \ldots \\ 34 \mathrm{E} 26 & 1 / 2 \mathrm{lb} \ldots \\ 34 \mathrm{E} 27 & \mathrm{I}^{1 \mathrm{lb}}-\end{array}$

$\$ .35$
$\$ .5 n$
-8.75

PREE-PLANT

Suerds up yermination. makes for sturdler hrowth and better production. Combines

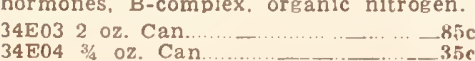

TRANSPLANT TABLETS

Counteracts root shock and wilting in Hormones plus B-Complex. 2 tablets make gallon.

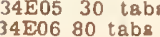
$35 \mathrm{c}$
GAr

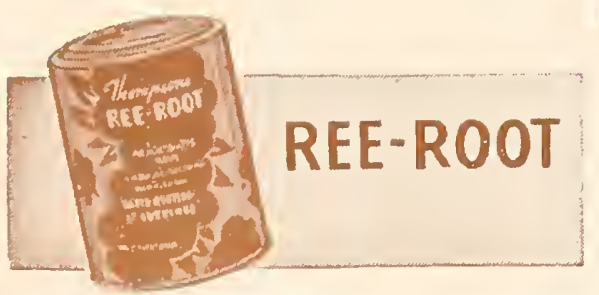

\section{REE-ROOT}

A recently developed hormone B-Complex curtings. No 1 for more sensitive plants. No. 2 ior hards plants.

34E07 Ree-Root for sensitive plants 34E08 Ree-Root for hardy. woods plants
No. 2 l H $_{2}$ oz

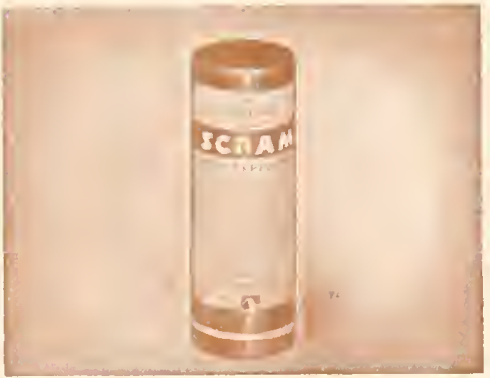

SCRAM DOG REPELLENT To keep dogs awas from the plarits 33E09

RAIN KING, MODEL H

ideal for Newly Seeded Area

tstanding sprinkler that's a sure vinrantee of beautiful lawns. Sprinkles issed for revolving or stationary sorink. unes are solld bress, chromlum Bronze bearines, exposed brass parts chrnmlum plated. Heavy. baked-n
-namel I1n!sh $34 \mathrm{E} 28$ Model H. $\times 3.25$

RAIN KING, MODEL D america's Quality Surinkter.

Nozzles can be easily set to water clrcles

ncrs. Each nozzle a sprinkler in itself utuckly adjusted for distance, direction and volume, elther revolving or stationmeter. Model D has gleaming brass prinkler finished in enamel. 9 inches linished in enamel. 9 Inches
laches wide at base 34 E29

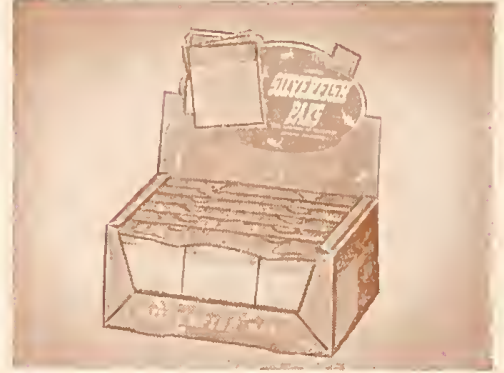

DEKKO SILVERFISH PAKS

Silverfish are insidious and hard to copo
with--but Dekko does it! Place paks it closets bookcases. under rugs, etc
34 E10 Postrald

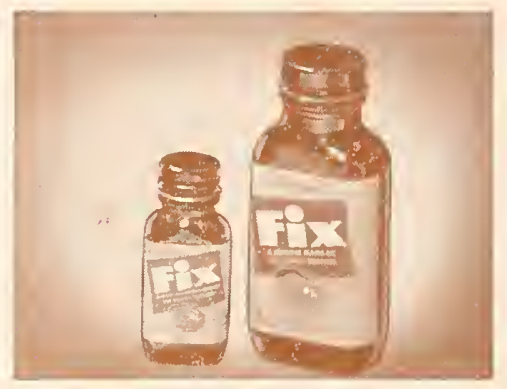

FIX

A multi-hormone bloom-set for seedles. tornatoes. First tomato blossoms ar those which usually fall to "set." Yo: result have seedless tomatoes much ear 34 E11 20 tablets make 20 qts. solution 35 34 E12 40 tablets make 40 ats. solution $65 \mathrm{c}$ 4E13 100 tablets make

81.211

\section{ROOTONE}

Rootone stimulates the natural tendenc for roots to form on slips or cuttings When seeds and bulbs are dusted with
Rootone and planted. germinatlon is Rooton

$34 \mathrm{~F} 18 \mathrm{1} / 4 \mathrm{GZ} \ldots \ldots \ldots \ldots$

\section{VITAMIN BI PELLETS}

Thompsons standardized ration of Vila min $B^{3}$. plus important factors of Vlia

34 E14 Box of 200 pellets
34 E 15 Box of 50 pellets. $\$ 1.14$

\section{FIREPLACE CRYSTALS}

Effective, long lasting, produces brlllian and Redwood package desten- burns on! when in the fire. $34 \mathrm{E} 16$

\section{ELKAY VALVE hOSE NOZZLE}

The Elkay Nozzle operates with mese touch of a fingertip, and makes possib! Eins and diNozzle is made of an amazing light. weight, non-corrosive metal alloy. It extremely durable, having a higher tell-
slle strength than cast brass. $34 \mathrm{E} 30 \mathrm{EI}$.
kay Nozzle, $\$ 1$. fis.

\section{"TAP REEL"}

The new "Tap Reel" is deslgned make watering and gardenlag a pleasure. The hose is connected to the hose con the tap. The water passes through the reel into the hose making it unnecessars to connect and disconnect the bose each tine it is used. yet It is alway ready for lnstant use colled up and
out of the way. 34E31 rap Reel.

SAFETY SNAP-ON ELOWER POT HANGER Made of strong wire, easily snaps on
rim, making any flower pot a "hanging

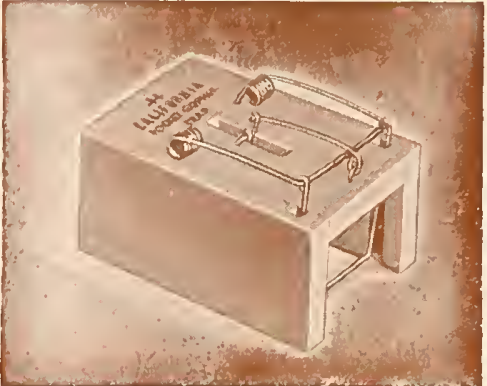

\section{CALIFORNIA GOPHER TRAP} No. 44

The slandard box trap for gopher trat ping. powerfu

$34 \mathrm{E} 17$

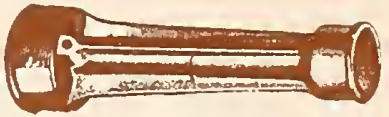

THE HAYES SPRINKL-AIR

Amazing new type nozzle! It's the alr that does it! Mixes alr into water flow. ling through garden hose $\begin{gathered}\text { almost } \\ \text { magically changes harsh stabbing streams }\end{gathered}$ magically changes harsh stabbing stream.

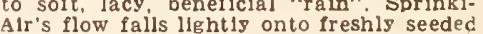
lawns and gardens onto no washluk away of earth and seeds no damage to tender seedllngs and thn plants.

Only $\$ 1.10$

\section{FRUITONE}

Frultone has been found elfectlve in keeping varlous knds of howers, leave and hrults on the tree or plant longer

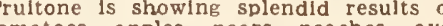
tomatoes, apples, pears, peaches, avo plants and trees $34 \mathrm{E} 12 / 5$ oz $34 \mathrm{E} 2$ 2 oz.

\section{TRANSPLANTONE}

Transplantone helps grow new roots and reduces loss of water so the plant start rich as tomatoes celers stramperries. tch as tomatoes. celerg, strawberries. much more rapld growth after trans planting

$34 \mathrm{E} 19 \cdot 15$

\section{SELF-SET GOPHER AND} MOLE TRAP Easy to Use
use the amazing Ses, even a chlld can The self-set is automatically set by holding the trap at a downward anele and simply squeezing the handeri

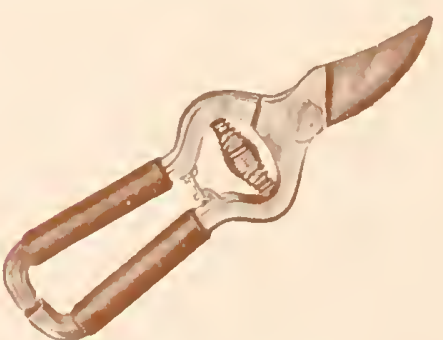

\section{CORONA CLIPPERS}

"Fur a Cut Above the Averake" No. 80 Heavs duty Rleser pattern cllpre or rugged pruning. Neoprene handles Rubber bumpers prevent plnching Lone
lasting sharpness. 34 E33 Corona Cilppeength $83 / 16^{\prime \prime}$. \$8.18.

\section{NEW NO-BLIST'R LIFETIME} RUST-PROOF TROWEL cientificaliy Designed to Prevent Blis Cast Aluminum

Llghtwelght, attractlvely designed, blade and handle are molded as a single unt rom alumlnum for durable llfetime. rust-proof service. 34 E34 No-Bllst

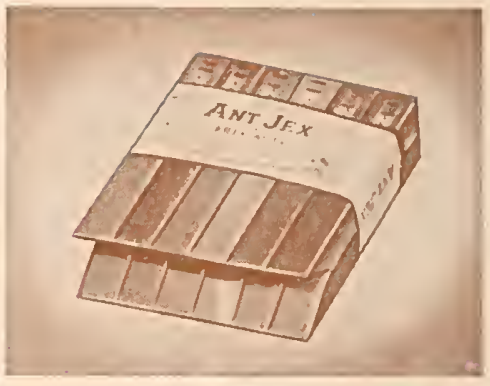

ANT JEX (Improved Ant Stakes) Ant Jex Ant Polson is made in gelatio form and inclosed in stakes, bence no and pers.

34E20 Dozen

$-81.41$

\section{PLANT-CHEM \\ For Vepelable Gardens Flower} The ideal all-purpose fertillzer. A scle iflc balance of the blg 3 plant nutrien: orether hormone.

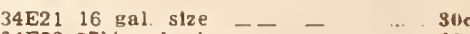

$34 \mathrm{E} 22371 \%$ Bal size,$--- \ldots$ AOC

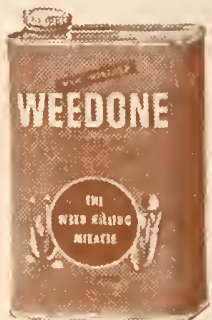

NEW IMPROVED WEEDONE

A marvelous new weedkller. When th emulsion is sprased on the leaves of cercaln weeds the 2-4-D is absorbed by the Dlant and peretrated is absorbed by the Weed lawn weeds without killing the desirable lawn and pasture grasses, or the cereal cropa.

$34 E 24 \quad 8 \quad 02-11.10$

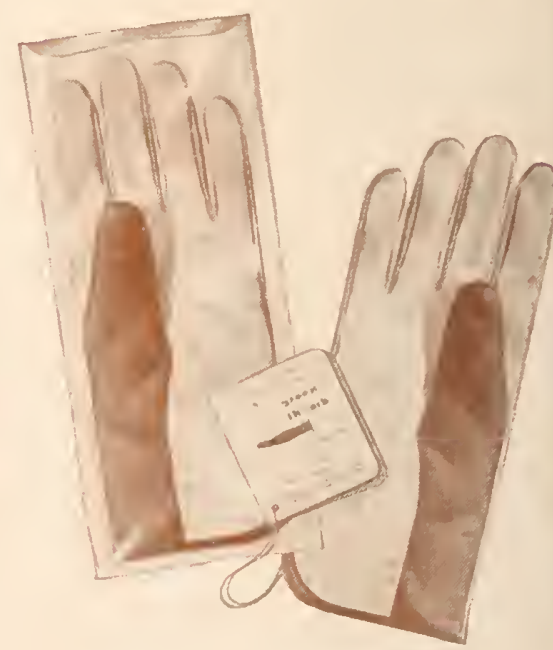

"GREEN THUMB" GLOVES Vinyl treated, dirt-repellent, washable and they actualls have a green thumb Sroen chumb. Indlvidually pack green thumb. Indivlduaily packaged large. 34 E35 Grees Thumb Gloves. 99e

GRANT'S DOG REPELLENT

\section{Keeps Dogs Away.}

After years of research Grant Laboratorles have developed a chemically concen sealed all-metal contalner it is a weather (t) a weather THAT DOG! From destroying lawn shrubs, trees, gardens, etc. Package of six individual repellents 34E36 Dog $\mathrm{R}$ pellent. \$1.1n 


\section{ORTHO GARDEN AND NURSERY SPRAYS}
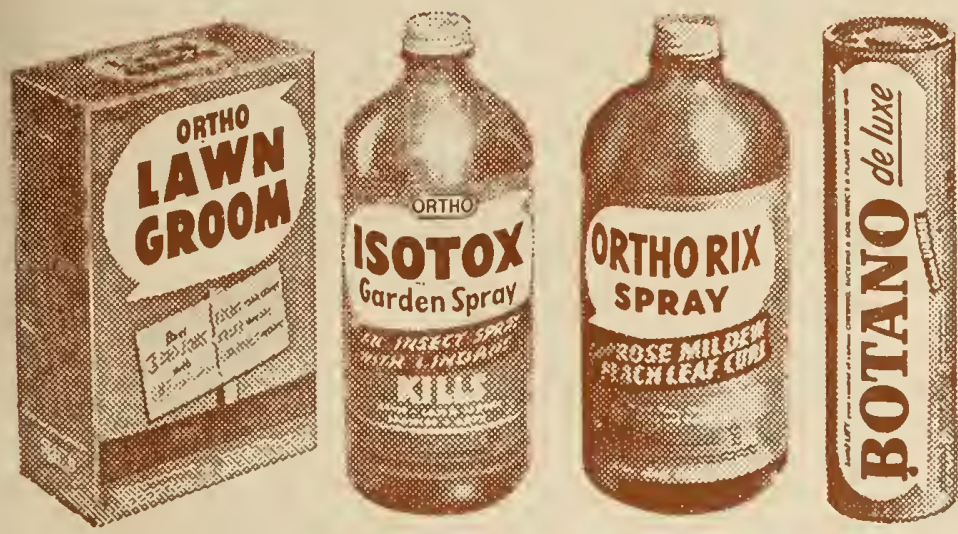

ANT-B-GON Ant control Liquid and Dispenser. The new method of Ant Control with "Sweet wick" dispenser. The
patented "Wick" does the trick. Set of patented "Wick" does the trick. Set of of Syrup-35E01 \& oz. 4nc: 35E02. 16 oz. of $\mathrm{s}$.

\section{BOTANO DELUXE DUST}

Improved mult1-purpose dust mixture in self-use duster package. For use on oragalnst 16 different garden pests includ. ing certain Ants. Aphis, Beetles, Black Spot Diseases. Caterpllars. Red Spidcr. $35 \mathrm{E} 03$ Del Rue Ducter Oz. $\$ 1.05$ : 35E04. 1 Lb. 1.15.

ISOTOX GARDEN SPRAY W ith Lindane-Kills Aphls. Lawn Moths. Earinsects and many other pests. very effectlve pest control for general garden or greenhouse use on Roses, Camellias. Ornamentals, Shrubs, Trees, Fiowerin, Plants, etc. $35 \mathrm{E} 052$ oz, $75 \mathrm{C}$

GARDEN BORDO MIXTURE FO blisht. rust and fungus diserses. 35E08 BUG-GETA METALDEHYDE BAIT A new snall and slug balt for control of sna1s, slugs, earwigs, Erasshoppers, cut worms. Contalns Meta-Acetaldehyde.
35E09, 21/2 lbs., $95 \mathrm{c}$; $35 \mathrm{E} 10$, 6 lbs., $\$ 1.95$ BUG-GETA PELLETS Th1s new Metaldehyde-Arsenlc Balt in pellet form. Bug Gelf Controls Snalls, Slugs, Cutworms. Sow Bugs, Earwigs, Grasshoppers and Straw35E12, 2 lbs., 95e: 35E13, 5 lbs., \$1.9i: 35E14, 25 lbs., \$7.05.

LEAD ARSENATE A stomach polson for chewing insects. 35E15. 20 ozs. $\$ 1.15$ 35E16, 4 LS., $\$ 2,05$,

FLOTOX GARDEN SULPHUR Is the superfine flotation type sulphur for all
around home garden use. 35E17, 26 oz., super
around
35c.

\section{HAYES-ETTE SPRAYER}

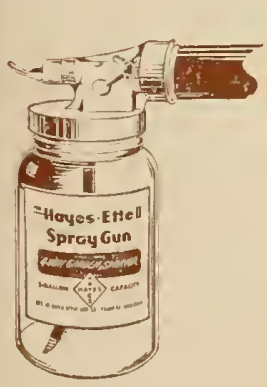

AT LAST! A compact little bantanweight that efficiently does the work of many larger sprayers Weighs just a little over a pound, filled Simply attach to gar. den hose, lightly press the new No-Leak Thumb Button-that's all! ideal for use with spray kits.

35E93

$\$ 5.70$
VOLCK OIL SPRAY A summer oll spray and spras carrler for use agalnst Spider, White Flies, 35E18, 4 oz.. 45e: 35E19, 16 oz.. 85c.

EXTRAX GARDEN SPRAY A contact Insectlcide. Used as a general purpose garden spray against Aphis, Thrips. Rz.. 69: : 35E21, 4 nz.. \$1.10; $35 \mathrm{E} 22$. GREENOL LIQUID FUNGICIDE Used agalnst Rose Milldew, Blackspot. APPO CUTWORM BAIT Appo is a poisoned apple bait useful in controllin cutworms, strawberry root weev11, ear.
wigs. slugs and a number of other simi lar pests. 35E25. I lb., 60c.

SOIL FUMIGANT For use agains Cabbage Maggot. Onion Maggot, Cen:1pedes. Wireworms, Sod Web Worms (Lawn Moth)

ISOTOX GARDEN DUST Contalns Lindane. An excellent garden dust to control Aphis. Thrips, Caterpiliars, Earworms, Sod Web Worms and Many other pests. 35E28. $1 \mathrm{lb}$. 98c.

ORTHO LAWN GROOM Does 3 blg jobs with one appllcation. Feeds the lawn, k11ls weeds controls insects such
as lawn moth, wireworms. 35E29, o lbs.

ORTHORIX SPRAY A fine year 'round spray, for Powdery Mildew, Black Spot, Rust and Red Splder mites; and also Scab. San Jose Sale, Peach Rust, Peach Leaf Curl, and B B

ORTHO SPRAY SET For many Rose and Garden Pests. contalns 1-4 ounce bottle of Isotox Garden Spray, $1-4$ Ortho Soray Set, $\$ 1.55$.

ORTHO CRA B GRASS KILLER Contains Phenylmercuric Acetate. Kllls ugly crab grass (water grass. wire grass
or full grass). 35E33. 4 tbs.. $\$ 2.26$.

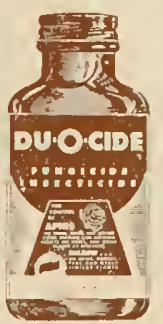
dew. Leaf Spot, Aphls and Chewing In DU-O-CIDE GARDEN DUST fol in milliple pest control in dust and leaf spots on Snapdrakons. Chrysanthemums. Roses. Carnations. Sweet Peas Iris.
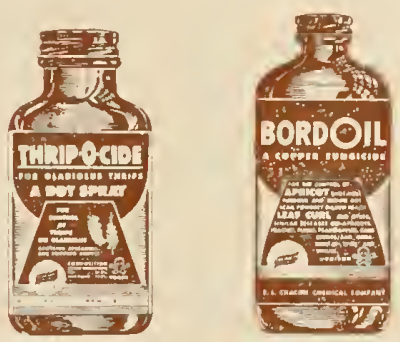

THRIP-O-CIDE An outstanding Thrip control for Gladiolus, Roses, Dahlias and other fast growing flowering plants. Also effective for beetles, cankerworms. elm caterplllars, rose and cherry slugs
$35 \mathrm{E} 84,2$ oz. 65c: $35 \mathrm{E} 85,4$ oz., $\$ 1.15$.

BORDOIL Controls shot-hole fungus. brown spot and simllar fungus diseases An Almonds, Cherries, Nectarines.
Peaches and plums; leaf curl on Peaches: Peaches and plums; leaf curl on Peaches;
mildew, etc on Apples, Pears, Roses, mildew, etc on Apples, Pears, Roses, Fuchsias and other trees and plant

\section{CHA-KEM-CO \\ MODERN PEST \\ CONTROLS}

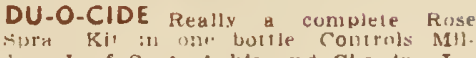
sects. 35E75. 2 az. $75 \mathrm{se:}$ 35E76. I plani diseases. such as Mildews. rusts

SCALE-O-KIL recuminended 10 , Spider mites in cltrus or a avocado trees Camelilas, Gardenlas, Eugenlas, ollve trees. etc $35 \mathrm{E} 80$. 8 oz.. 9ne: $35 \mathrm{~EB} 8$. ot.

SULF-O-ZIDE

to Hole disease on peaches, nectarines and cherrles and other stone fruits. In sprine and summer controls Blackberry mite and tomatr
at. $\$ 1.50$.
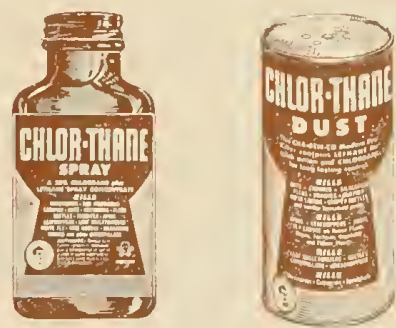

CHLOR-THANE SPRAY A $25 \%$ Chlor dane plus Lethane Spray of fast action and lons-lasting qualties. Remarkabl effective on soll insects. leaf chewers.
sucking insects. $35 \mathrm{E} 88$ oz., $\$ 1.15$ 35E89, pt. \$3.10.

CHLOR-THANE DUST Controls same pests as the Spray, plus household pests as Ants, Roaches, Carpet Beetles, S1lverPz., 400; 35E91, 12 oz., 690.

CORNWORM SPRAY YOu may now enjos wormless roasting ears with just

\section{MISCELLANEOUS INSECTICIDES AND FUNGICIDES}

FUNGTROGEN A concentrated form of copper used in the control of Mildew and Black Spot on Roses. 35E51, 1/2 Pt.,
$85 \mathrm{c}$; $35 \mathrm{E52}$, 1 ot., \$1.40; 35E53, 1 at.,

NICONA A nicotine and oll spras, effective against Aphls, Thrips, Red Spider. Scale, Mealy Bug and Mildew. Prices: $35 \mathrm{E} 55,4$
$35 \mathrm{E} 7$, RED ARROW A Contact Pyrethrum and Rotenone spray used in control of suck1ng insects. 35E59, 1 oz., 45c:
$35 \mathrm{E} 60$.
PULVEX Powder for doss, cats, and canarles. Dust the powder well and rub 35 c: $35 \mathrm{E} 63$. 3 3 $3 / 5$ oz. for dozs, or e.ats.

FRESNOL ANT SYRUP is the onls ant syrup that kills all 7 specles of ants that invade Calliornia homes and gardens. FRESNOL has a special attraction for ants; they seek it in preference to
all other foods in the home. Jars (Set of 4 filled) 750 : $35 \mathrm{E} 64,8$ oz. size, 600

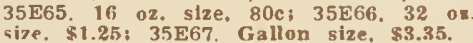

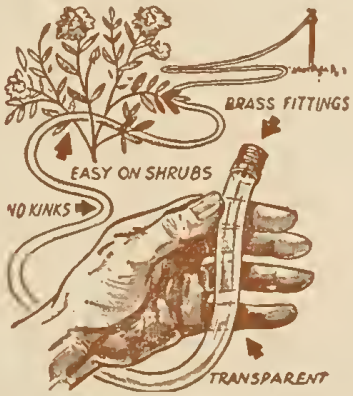

\section{New AMPECO Clear Amber Garden Hose Long lasting, very light $1 / 2$ usual weight) mo oth non sorling. -revolutionary in every \\ way $5 / 8$ " Size \\ $35 E 9425 \mathrm{ft} \ldots \$ 6.80$} $35 E 9550 \mathrm{ft} . \quad \$ 10.45$

Clear Green VYNAL Garden Hose 3/8" Size

$35 E 9625 \mathrm{ft}$

S 5.80

उ5E97 $50 \mathrm{H}$

$\$ 8.45$

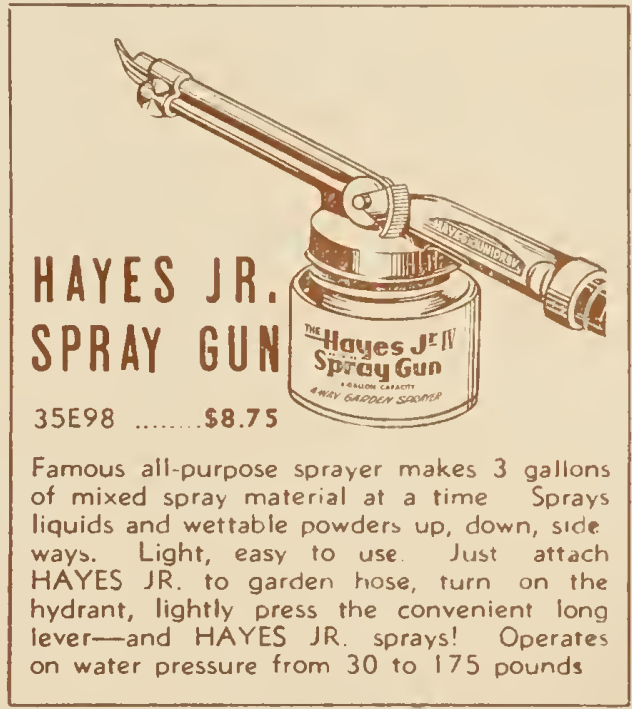


A

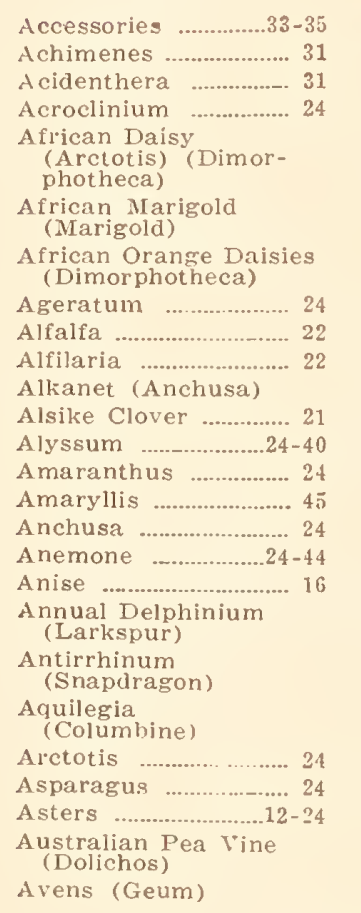

\section{B}

Baby Blue Eyes
(Nemophila)

Baby's Breath
(Gypsophila)

Baby Snapdragou

(Nemesia)

Bachelor's

Button ….............24-10

$\begin{array}{lll}\text { Balsam ........................... } 24 & 24 \\ \text { Basil .......................... } 16 & \end{array}$

Basket of Gold

(Alyssum)

Beans, Ficld ................ 25

Bcans, Table ..........14-15

Beard Tonguc

(Pentstemon)

Beets ........................... 1:

Begonia .................24-13

Bellys ........................... 24

Belvederc (Kochıa)

Bent Glass .-.............. 2 I

Bcrmula Grass ......... 21

Birdsfoot Trefoil ...... 21

Blackeye Beans ........ 22

Blackeyed Susan

Blanket Flower

(Gaillardia)

Blue Girass.

Books

Lorage

Borecole

Broccol

Brome Grass

Bugloss (Anchusa)

Bunch Primrose

Bullus ..................-31-43-46

Bur Clover .................. 22

Burnet ........................... 22

Butterfly Flower
C

Cabbage ........................ 16

Cactus ............................9-24

Caladium
Calceolaría

Calendula ................... 25

Calif. Native Flower

California Poppies

Calif. Windbreak

Calif. Windb

Calla Lily

Calliopsis

25

Candytuft

Candytuft ................... 25

Canterbury Bells

(Campanula)

Cape Forget-Me-Not

(Anchusa)

Caraway ...................... 15

Cardinal Climber ..... 25

Carnation ..........25-38-42

Carrot …............................ 16

Casaba .............................. 19

Cathedral Rells

(Coboea)

Catnip ...............

Cauliflower

Celery ............................ 16

Celosia .............................. 23

Centaurea (Sweet

(Bultan)

Cherry Pie
(Heliotrope)

Chinese Forget-Me-

Not (Cynoglossum)

Chincse Woolflower

(Celosia)

Chives ............................. 16

Chrysanthemum ......... 25

Cineraria 25

Clarkia ................................ 25

Clivia ............................. 29

Clover Seed ............21-22

Coated Seeds .............. 23

Coboea ……................... 25

Cockscomb (Celosia)

Cocksfoot (Orchard

Grass)

Coleus ............................... 25

Collards .......................... 10

Columhine ........................ 25

Convolvulus

rning Glory)

Coral Bells (Heuchera)

Coreopsis .................... 2 бే

Coriander ................... 16

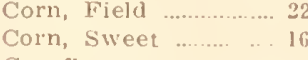

Cornflower
(Bachelor Butcons)

Cosmos ..............25-40-4

Corel Crop seeds..... 22

Cress …....................... 14

Cucumber

Cyelamen ....................... 25
Cynoglossum

\section{D}

Uahlias
Dassy (Arctotis. Dellis Dassy (Arctotis, Bell
Brachycome, Ger-

bera, Shasta Daisy) Dallis Grass ……....... 22 llicrls (Candyturt) Dianthus (Sweet William) (Carnation) Dichondra ……............ 21

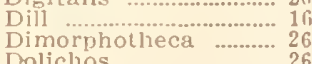

E

\section{F}

Farewell To Spring

(Celosia)

Flame Nettle

(Coleus)

Flax (Linum)

Flowering Suge

Flowering Tobacco

Fountain Plant

Fringe Flower

(Schizanthus)

Gerbera

Geum

Gladiolus

\section{H}

Harding (irass

Helianthus

Helichrysuin

Heliotrope

Heuchera

Hibiscus

11 ollyhock
$110 t$ kaps

Hubam cinver chos)

Insecticide ..................

(Morning Glory -

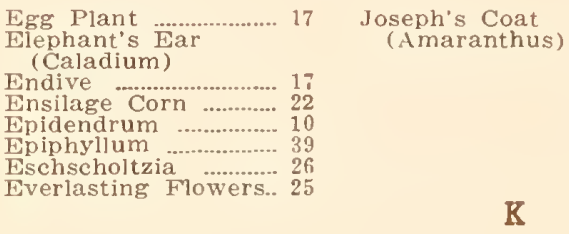

Feathered Cockscomh

Fescue Grass ..........21-22

Filcoat Flower and

Floss Flower (Agera

Flying Disk ............29-3?

Forget-Me-Not (Cyno-
glossum, Myosotis)

(Amaranthus)

of Peru)

Fox Glove (Digitalis)

Fragrant Flowers 28

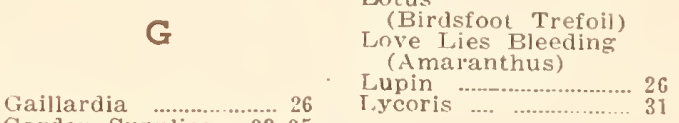

Gaillardia $\quad \ldots . . \ldots \ldots \ldots . . . . . .26$

Geranium ……........9-26

Gloxinia

Golf Course................. 26

Golf Course Seed......... $\frac{21}{42}$

Grasses, Lawn and
Golf Courses .......... 21

Grasses, Pasture and

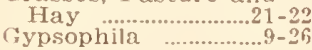

Hunnemannia …........ 2

Cardinal Climber) Iris ........................
Ismet
Italian Forget-Me-Not
(Anchusa)
J

O

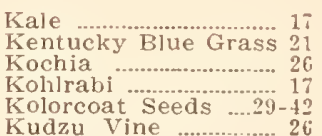

Painted Daisy .......... 40 (Chrysanthemum)

Papaver (Poppy)

Parsley

Parsnips

Pasture Gras

Peas, Field

Pelargonium

Pelargonium

Pentstemon

Ladies' Slipper (Bal-

sam) Clover

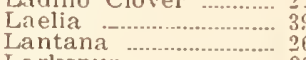

[arkspur Perennial

(Delphinium)

Lathyrus

Lawn Seed

Leaf Cactus

Lespedeza

Lily …….................... 17

Lily of the Valley....

Linaria

.

(Birdsfool Trefoil)

(Amalanthus)

I.ycoris

Peppers ……................

(Delphinium)

Perennial Sweet re:

(Lathyrus)

Persian Buttercup

(Ranunculus)

Petunia ……........ $2 \overline{7}-40-42$
Phlox ………... $97-37$

Pincushion Flower

(Scabiosa)

Pinks (Dianthus)

Planting Chart ............ 23

Poa ……................. 21

Poppies ………..... 27

Poppy (Eschscholtzi

Hunnemania)
Portulaca ..................2 $8-41$

Pot Marigoli

(Calendula)

Primose (Primula)

Primula

(Primion
Pruners

Pumpkin

Purple Vetcl

(Calceolaria)

M

Pyrethrum

Mad Wart (Sweet

Alyssum)

Mallow: (Lavatera)

Marigold ……27-40-41

Marigold (Calendula)

Marjoram

(Hisbiscus)

Marvel of Peris

(Ronmeya)

Melilotus

Melons …........... 14

(TIthonia)

Mignonette
Nilo Naize

Milo Maize

Montbretia

Noon Flotwer

IIourning Brid

(Scabiosa)

Mruskmelon
MI ustard

Myosotis

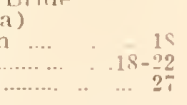

N

Nasturtiums

Nemesia

Nemophila
Nicotiana
Nierembergia

vierembergia

Sorghum

Spanish Fla

(Mina)

spi-Cee-Cres

Spider Lily (Lycorls)

Sprekelia

Squash

Statice

trawberry Clover $28-4$ Straw Flower

(Helichrysum)

Strelitzia

Sudan Grass ....

(Kor Cypress...... 22

Sunflower (Helianthus) Sun Plant

Sweet Clover

sweet Plover ................

Sweet Scabious

(Scabiosa)

Sweet Scented Gladio-

lus (Acidenthera)

Sweet Sultan

Sweet Villiam

Swiss Chard ............ 16.

\section{T}

Texas Plue Bunnet... Texan Pride (Phlox) Thunber

Tiger Flower (Tigridi Tigridia 


\section{ORDER BLANK}

for SEEDS, BULBS and ACCESSORIES GERMAINS

LOS ANGELES 21, CALIFORNIA

Mr.

Date of Order

Mrs.

Miss

Please write your name plainly and give address in full.

Terms-Send Remittance in full with order. We cannot accept C. O. D. orders. All shipments are sent PREPAID.

You pay nothing extra.

If merchandise is to be sent to another address. please print or writo olainly.

SHIP TO

R. D. or Street and No.

Name.

\section{Post Office}

Express Office

If Different from P. $O$.

In case we are out of a variety yols order, we shall send another variety of the same color and equal or higher value, as most of our customers prefer it. If you do NOT wish us to substitute, please mark " $X$ " in this space.

NON-WARRANTY. GermuIn's Inc. glves no warranty express or implled, as to the productiveness of seeds bulb. is limited to the purchase price of the seeds, bulbs or plants.

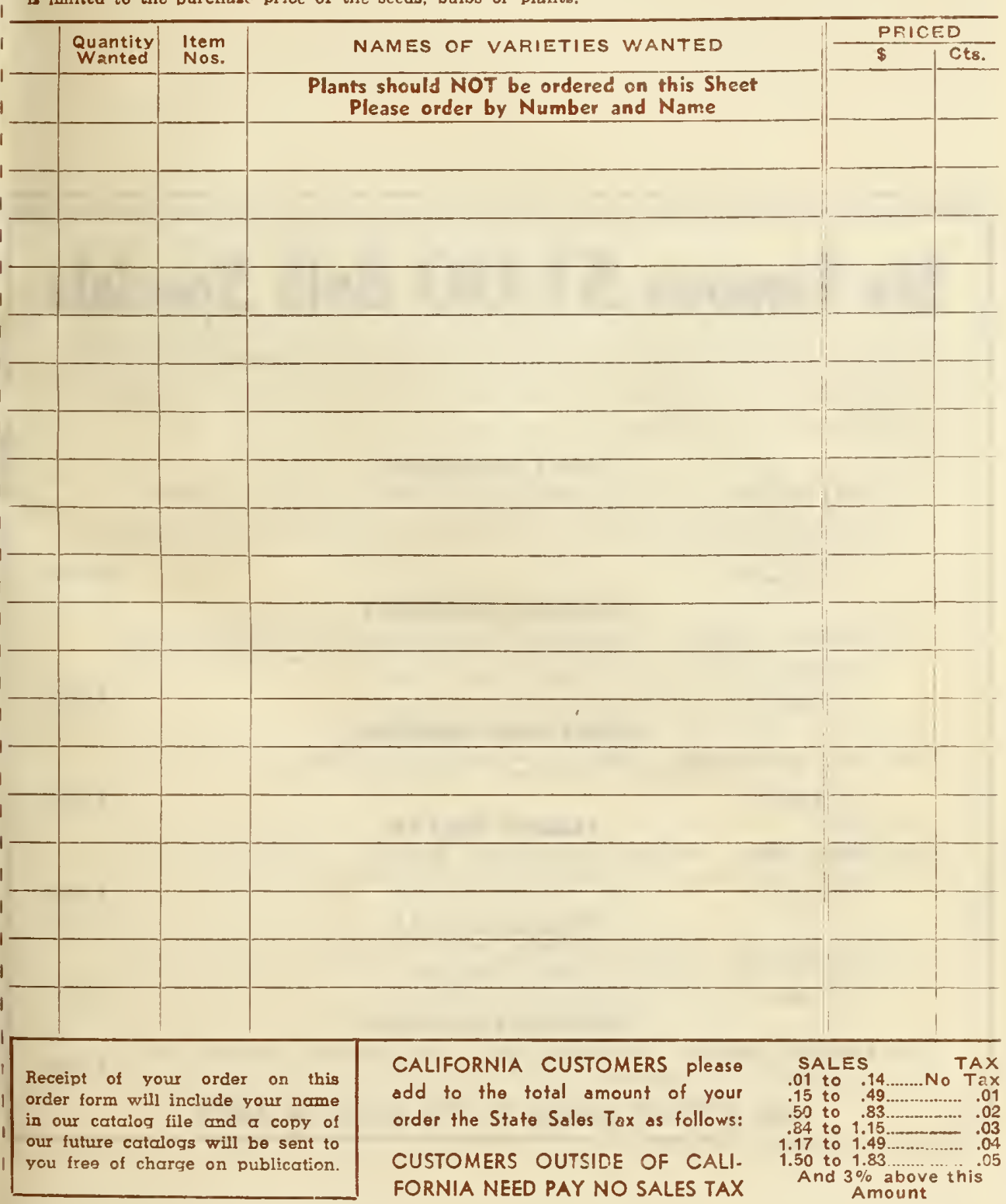




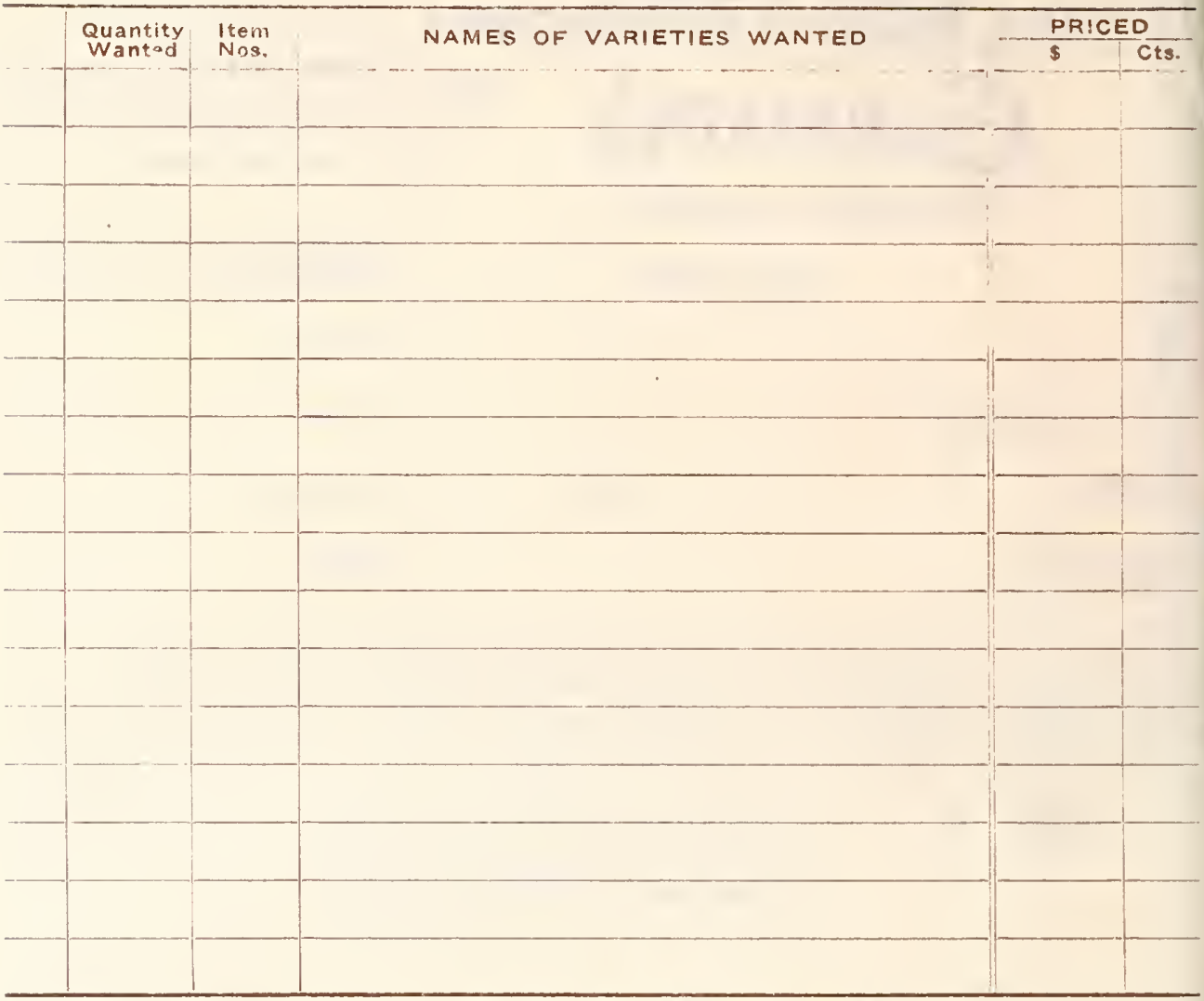

\section{Six Famous $\$ 1.00$ Bulb Specials}

In these amazing $\$ 1.00$ specials Germain's offers you a rare opportunity to grow a garden full of splendid bulbs at surprisingly low cost!

\section{GIANT GLADIOLUS}

5280 Giant Gladiolus. The most spectacular and easiest to grow of all summer bulbs. The beautiful 4 to 5 - $\mathrm{ft}$. spikes bear up to 18 giant 6 and 7 -inch blooms-5 each: Red, Yellow, Pink, Lavender, White. Plus I special novelty bulb.

26 bulbs.

\section{TUBEROUS BEGONIAS}

5100 Tuberous Begonias. Magnificent shade-loving plants, bearing huge camellia-like blooms in rich, velvety tones. One each: Red, Rose, Yellow, Pink, White, plus one new hanging basket type.

6 bulbs.

\section{FANCY LEAF CALADIUM}

5180 Fancy Leaf Caladium. Ideal pot and window box foliage plants. Exotic 2 and 3 tone harmonies-Reds, Pinks, Rose, Greens, etc.
5 bulbs.
is

\section{YELLOW CALLAS}

5148 Yellow Callas. Gorgeous golden yellow flowers on tall stems, beautiful spotted white leaves. Dramatic cut flower or attractive pot plant.

3 bulbs.

\section{PINK CALLA LILY}

5) 45 Pink Calla Lily. Most exquisite and rare of all Callas. Dainty flowers, 2 to $2 \frac{1}{2}$ inches across, of orchid shade pink.

5 bulbs.

DECORATIVE DAHLIAS

5636 Decorative Dahlias. Giant flowering in three beautiful separate colors

3 bulbs. 



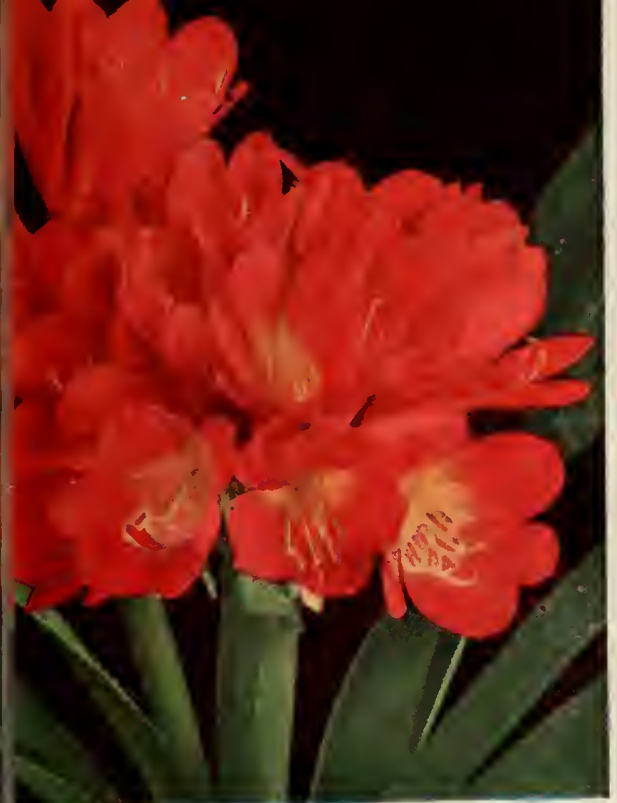

NEW HYBRID CLIVIA

\section{Clivia}

NEW HYBRID Clivias succeed best in dense shade and thrive under and the South they are more and more the dis. tinctive feature of finer landscaping for shade, while in colder climates they are outstandine pot plants for the home or conservatory. Whe to become pot bound, more blooms will be obtained.

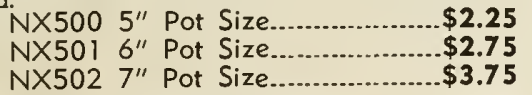

NX502 7" Pot Size......................\$3.75

Note: East of the Mississippi, please add $25 c$ to above prices.

Flawering Leaf Cactus

(Epiphyllum)

Free flowerinq. They are among the mos

prized and loveliest of all house plants.

varieties.

\section{Three Outstanding}

Varieties

HERMOSISSIMUS $\mathrm{T} h \mathrm{~h}$ coloring in this superb varable. Crimson, cerise and white.

NP173

ARGUS Larae, broad petaled flower of rich rose

pink. One of the best.

AMBER QUEEN Fine tone of deep amber blendina to rich copper. A areat favorite. NP175

Any of the above 3 for $\$ 2.00$ Or Collection: One each of the

three varieties.

NP177 $\$ 2.00$

\section{EPIPHYLLUM GENERAL COLLETION}

AGATHA Deep pink, red eye

NP179

CONWAY'S GIANT Maroon and cerise edge.

EDEN Pure white.

NP 180

H. M. WEGGENER Carmine and purple

NP187

PROFESSOR EBERT Deep Orchid. NP192

FLAMINGO Copper, cerise eye. NP193

Above Varieties Any 3 for $\$ 1.75$.

Collection of 6 for $\$ 3.25$. NP196

\section{Strelitzia}

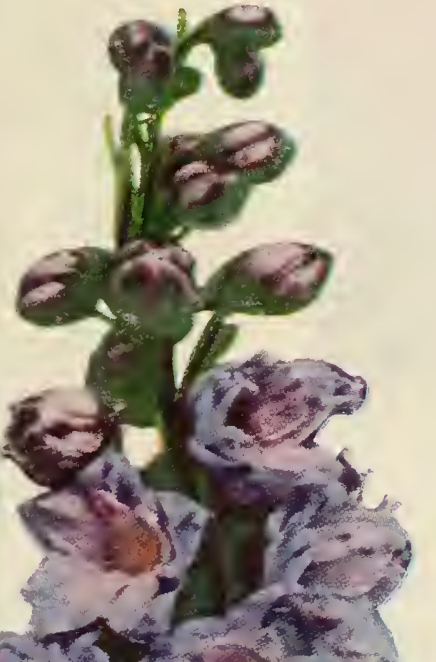

REGINAE (Bird of Paradise) Rivaling the tropical Bird of Paradise in splendor, this flower with its combination of red, yellow, blue and orange Easily grown out of doors wherever Oranges thrive or suitable as a tub plont in the colder sections. Should be left undisturbed in a sunny situation in. a rather rich soil and liberally watered for most time when cut. in great demand by florists every. where.

East of the510 3-year old plants $\$ 2.50$ each

\section{Laelias}

This class of Orchid is one of the easiest to grow and will thrive and bloom under the most adverse conditions. Grow in Osmunda fibre.

ANCEPS This variety has two to four flowers to a stem which arows two to three feet tall. The color is violet rose. Bloomina season October to
December. Grows on wooden slabs or in pots or baskets.

$$
\text { N×540. }
$$

$\$ 5.00$ each

AUTUMNALIS Flowers four inches across, borne three or four to a stem. Color rose purple easy to grow. Blooms Oct. to Dec.

NX54i ................................\$4.50 each

SUPERBIENS Flowers five to six inches across. Fragrant, with as many as ten to twenty purple on the maroins. Blooms Jan. to Mar

\section{Odantaglassum}

GRANDE The flowers are borne three or four to a stem and the individual flowcolor is yellow lined and spotted dark brown. Deep golden yellow throat. This variety does well under pot culture and a mixture of fibrous peat and decayed leaves in equal quantity suits them best. Plenty of drainage is essential for success. Shade lovina. Water moderately.
NX548................... $\$ 5.00$ each

\section{Delphinimm Pacific Aybrids}

We believe this strain of Delphiniums to be the equal of any strain in existence. Noted for their stiff stems and heavy foliag they are a standout in any garden. While easy to grow a few pointers a do be nuire lime is applied al pell-drained soil is essentiol to their well being. Keep crowns of plants above the soil line when planting. Sold in mixture only.

\section{OSMUNDA FIBRE}

The best medium in which to qrow Orchids. This material is very liaht and bulky. We can supply the fest grade, matter. NX559 \$1.00 per lb.
STRELLTZIA REGINAE

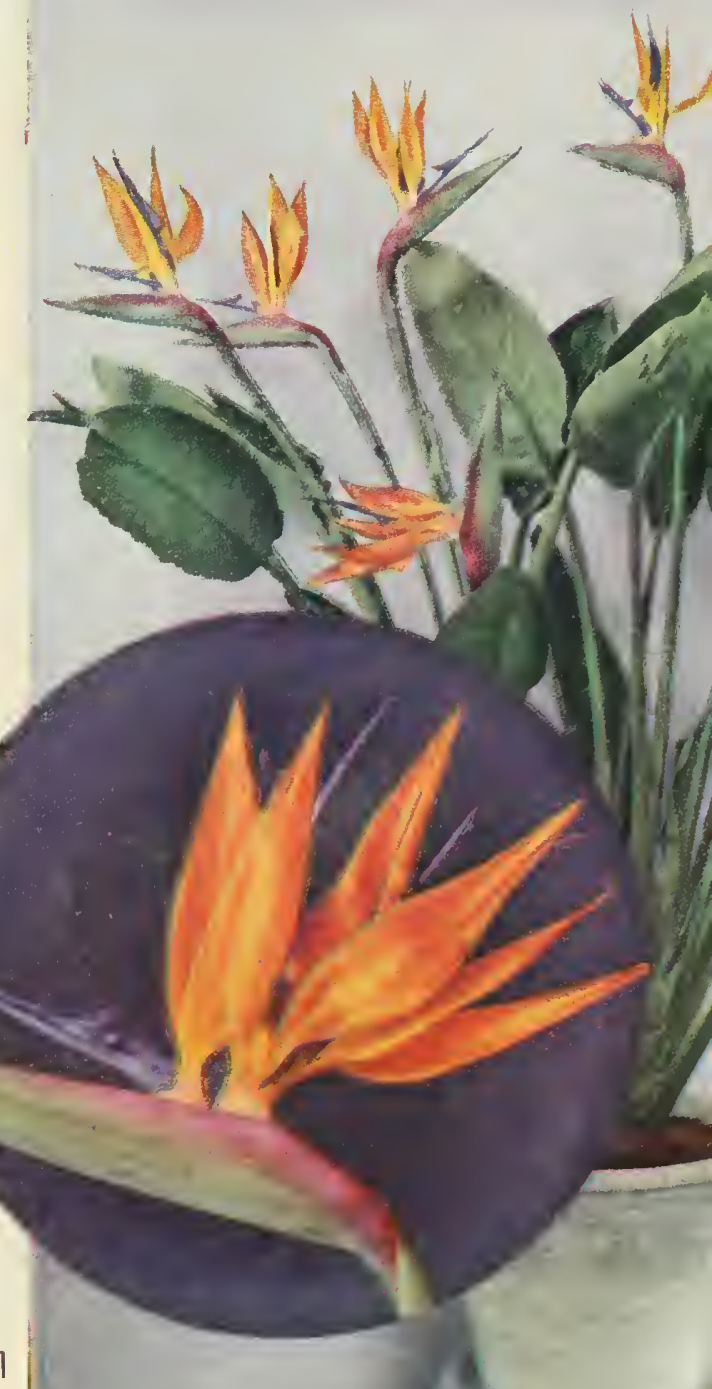




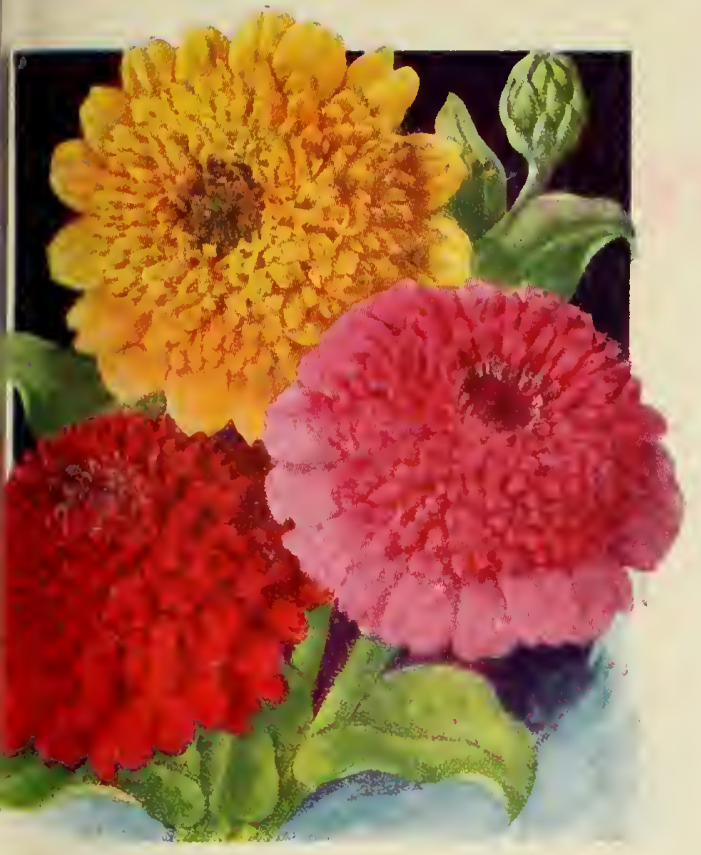

ZINNIA HARMONY CRESTED

\section{Nem Fantasy Binnias}

Fantasy Zinnias are unlike any other type of Zinnia qrown. The entirely novel shaggy appearance presented by their fluted, guilled and informally curled and crested petals is a pleasing surpris

4158 Melody. soft shade of lavender blue.
Pkt. $25 \mathrm{c} ; 3$ for $60 \mathrm{c}$

4153 Wildfire. A brilliant, flame scarlet, the most vivid sparkling of all red shades. $60 \mathrm{c}$

\section{DOUBLE CRESTED ZINNIAS Collection No. 41}

The three varieties of double crested Zinnias in this collection are amona the loveliest and most useful for cutHarmony Crested, Fantasy Melody

All Three Packets for $60 \mathrm{c}$

\section{New Marigald Spatlight}

3341 Spotlight. Saucy, sprightly and colorful. One of the qayest of new flowers. Distinctly new in the "Harmony" gloup, it bears an abundance in an arresting shade of gold, surrounded by a corolla of broad, mahogany red guard petals. Its wealth of blooms and vivid color makes each plant $\alpha$ flowers all summer long.

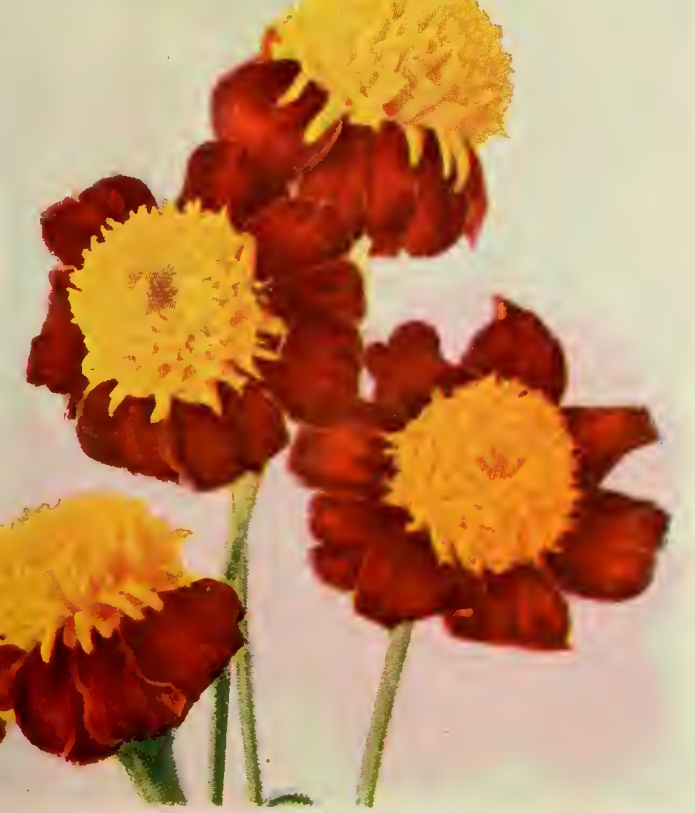

MARIGOLD SPOTLIGHT

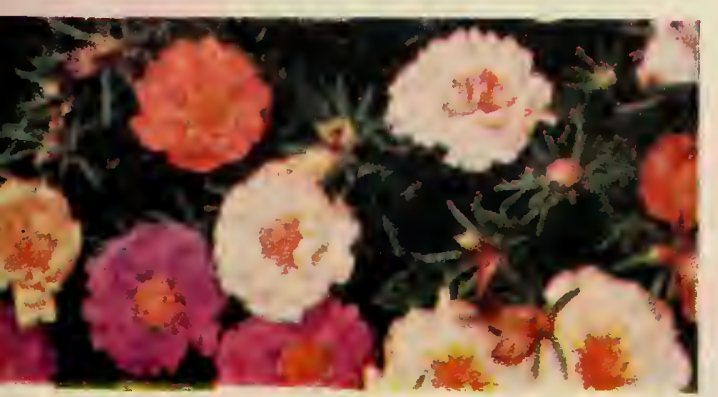

\section{Marigald}

GIGANTEA SUNSET GIANTS

3358 Sunset Giants Mixed. "Giganted Sunset Gionts" is a remarkable new sweet scented, robust qrowing extremely large flowered type of African Mariqold. The individual flowers are of huge 5 " to 6" size. The plants spectacular of all Marigolds.

\section{Dauble Crested Flowers COLLCTION No. $41 \mathrm{~A}$}

This novel collection of Double Crested Flowers for cutting will provide an abundance of blooms for artistic flower arrangements throughout the season. It con Crested. Aster Princess Mixed Giant Zinnia Harmony Fantasy Zinnia Melody and Wildfire. Marigold Spot

liqht and Scabiosa Rosette.
7 Packets (a $\$ 1.75$ value) for $\$ 1.50$

\section{Daule Rase Mass}

3720 Portulaca Double Choice Mixed. S u n loving unequaled for summer color in low borders, beds, edq ALL-AMERICA ADLECTIONS

\section{WINNER FOR 1952}

Casmas Fiesta

The festival colors of Old Mexico, com. r's maqic, bring this sparkling new-

comer All America's TOP AWARD for

952. For the first time-

mos: a new color for the

easy to qrow, Fiesta makes

a compact $21 / 2$, plant with a

Flowers are semi-double uffled, borne like tropico lt's a cut flower for the house, a handsome borde neat, trouble-free. Fiesto will be the most important year Don't miss it! 2777 Fiesta 3 Pkts. 60c; Per Pkt. 25c

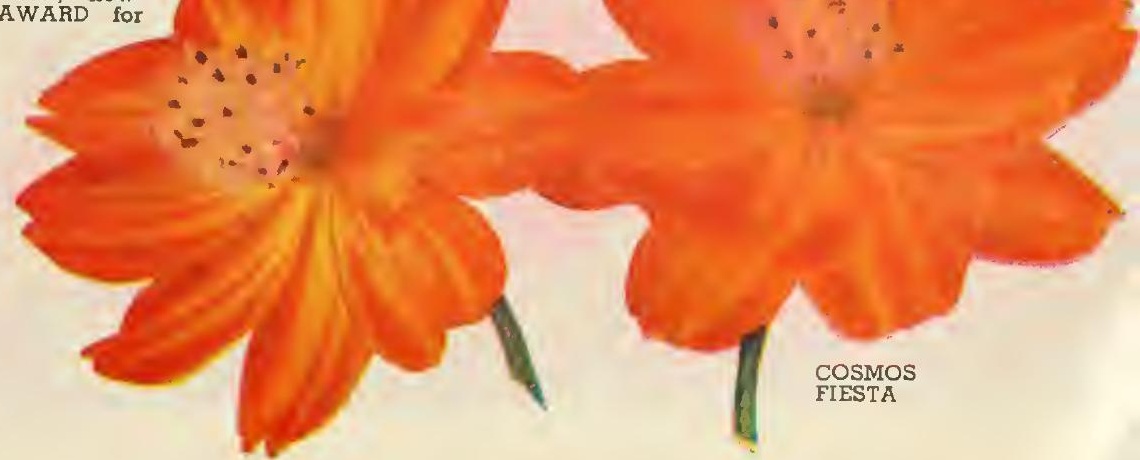




\section{for Spring Planting \\ Fancy Seaf Caladium}

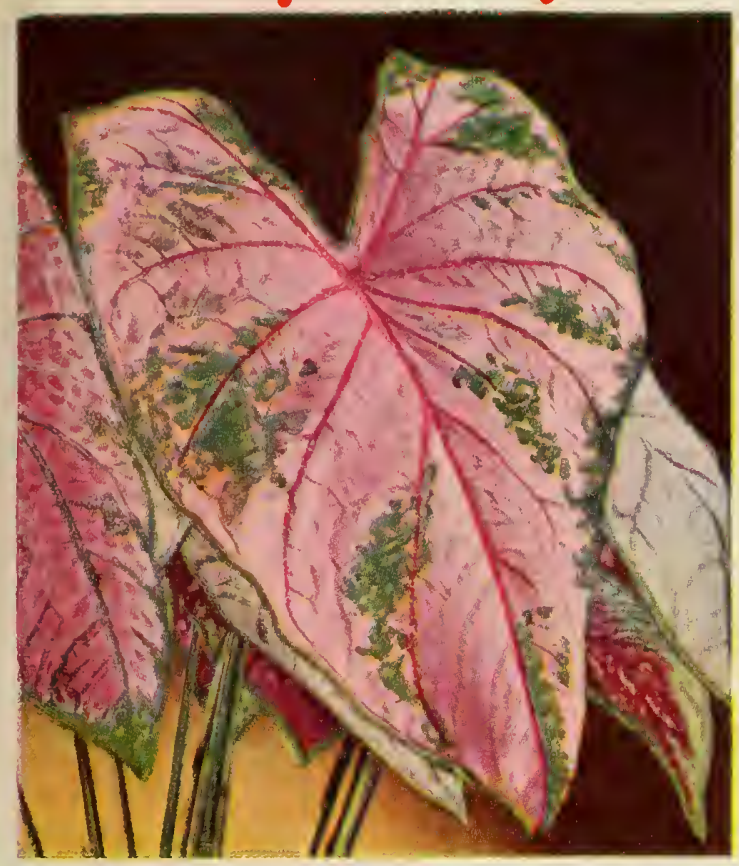

\section{Monteretias}

Montbretias are of easy culture, doing well in shade or full sun. Massed together in clumps they are effective and may be left in the ground without being lifted for years. They will bloom profusely throughout the summer and fall.

5850 Vesuvius. Dark blood red.

5851 Kathleen. Apricot scarlet, primrose center.

5852 Lemon Queen. Golden Yellow.

5853 His Majesty. Dazzling orange scarlet, yellow eye. 5854 Princess Mary. Petals pale yellow, tipped red.

5855 Lady Hamilton. Yellow center suffused with rosy Priced alike: 3 for 39 c; 6 for 79 c; 12 for \$1.49; 25 for $\$ 2.89$. COLLECTION No. 5860

2 bulbs each of the above 6 varieties for only $\$ 1.39$

Tigridia (Ferraria) Tigerflower

A splendid strain of this showy Garden Plant. The curous three-petaled flowers are very large and are wonderfully marked. Plant 2 inches deep and four to six inches apart in shade or half shade.

5770 White, carmine center. 5774 Pure Yellow.

5771 Light Yellow, red cen- 5775 Red Giant.

5772 ter. Ruby Oueen flower. 5776 Rose Queen, cle a $5773 \mathrm{C}$

rose color. center.

6 for 79c; 12 for $\$ 1.49$; 25 for $\$ 2.89$.

COLLECTION No. 5780. 2 bulbs each of the above $8 \mathrm{Var}-$

ieties. Not individually labeled. 16 bulbs $\$ 1.69$.

5778 Tigridia Finest mixture.

6 for 69 c; 12 for $\$ 1.19 ; 25$ for $\$ 2.29$; 50 for $\$ 4.19$
FANCY LEAF CALADIUM

Caladium provides a brilliant subject unexcelled for many uses. Taking little care, they are ideal pot plants for the home.

5160 Candidum. Fine Easter variety and very popular. Lea Snow-white with green veins and network, narrow green border.

5161 Crimson Wave. Large deep green leaf with crinkled, transparent crimson or scarlet center
spots towards edge. Strong qrower.

5162 Lord Derby. Transparent rose with dark green ribs and narrow green edge Very popular.

5163 Macahyba. Dark moss-green leaf profusely spotted lilac, heavy scarlet ribs.

5164 Mrs. W. B. Haldeman. Medium sized leaf of brigh pink with narrow green edqe.

5165 Reconcavo. A tine strong grower. Has a delicate rose center with carmine ribs. One of the best colors we offer.

5166 Rising Sun. Brilliant deep red center and ribs on dark qold tinted background, spotted transparent pink. 5167 Thomas Tomlinson. A Caladium of many lea Briqht crimson center and bloth

5168 Triomphe de l'Exposition. Roundish leaves of bright red dark areen edge.

5169 Scarlet Pimpernelle. Bright red center with scarlet ribs, leaf bordered creamy yellow.

$39 \mathrm{c}$ each; 3 for $\$ 1.09 ; 6$ for $\$ 2.09 ; 12$ for $\$ 4.09$ COLLECTION No. 5170. One bulb each of the ten v ieties listed above for only $\$ 3.39$.

COLLECTION No. 5175. One bulb each of Candidum Lord Derby, Macahyba, Rising Sun and Scarlet Pimpernelle for only $\$ 1.75$.

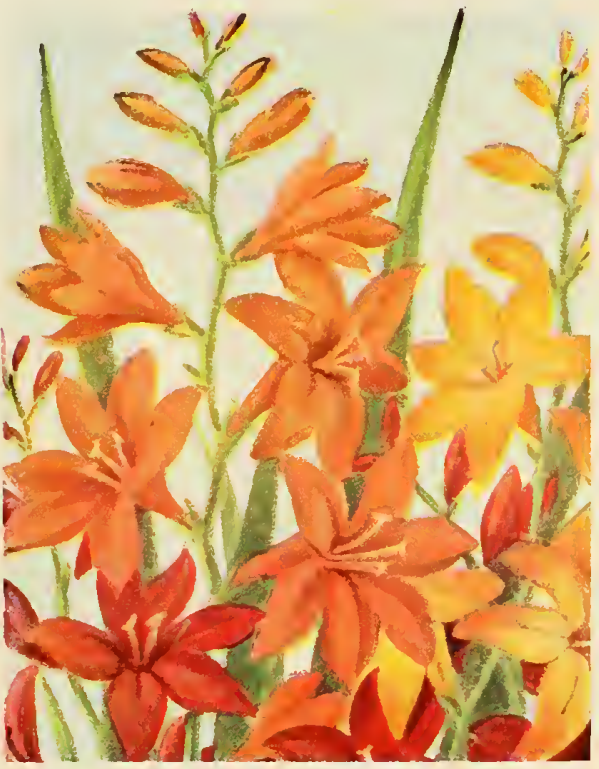

HYBRID MONTBRETIAS

\section{Grow Lovely and Fragrant}

\section{LILIES OT TIIE VALLEY} in the House All the Year'Round Clusters of charming pure white bell-shaped blossoms on tall graceful stems stand, full grown, just 3 weeks after you receive Germain's imported forcing pips.

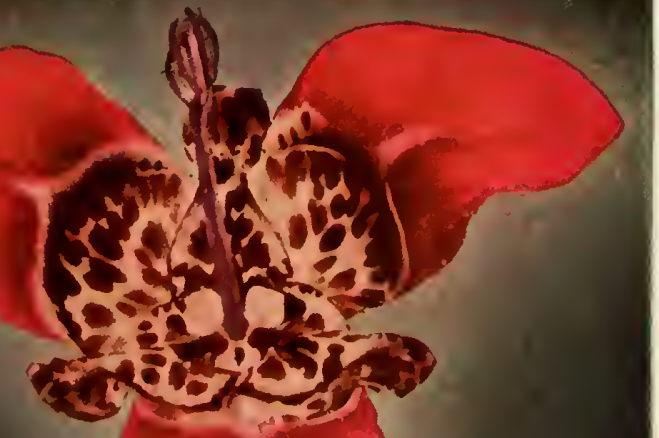

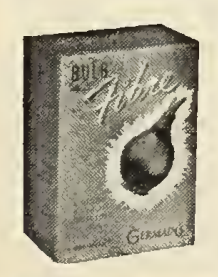

Six Lily of the Valley pips, No. 5361

12 Lily of the Valley pips, No. 5361

25 Lily of the Valley pips, No. 5361

$\$ .89$

$\$ 1.69$

5567 Pack

ing Lily of the Valley indoors.

PLANTED POTTERY CONTAINER No. 5362

Beautiful California glazed pottery Coffee

libre and planted with 5 Lily of the Valley

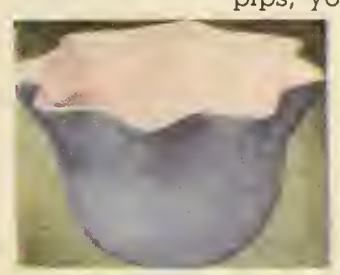

PLANTED CONTAINER

5363-Round Fluted pottery bow

with 5 Lily of the Valley pips \$1.59

LILY OF THE VALLEY PIPS

For Outdoor Growing Only

No. 5366

6 for 39 c; 12 for $69 \mathrm{c} ; 25$ for $\$ 1.29 ; 50$ for $\$ 2.49$; 100 for $\$ 4.69$.

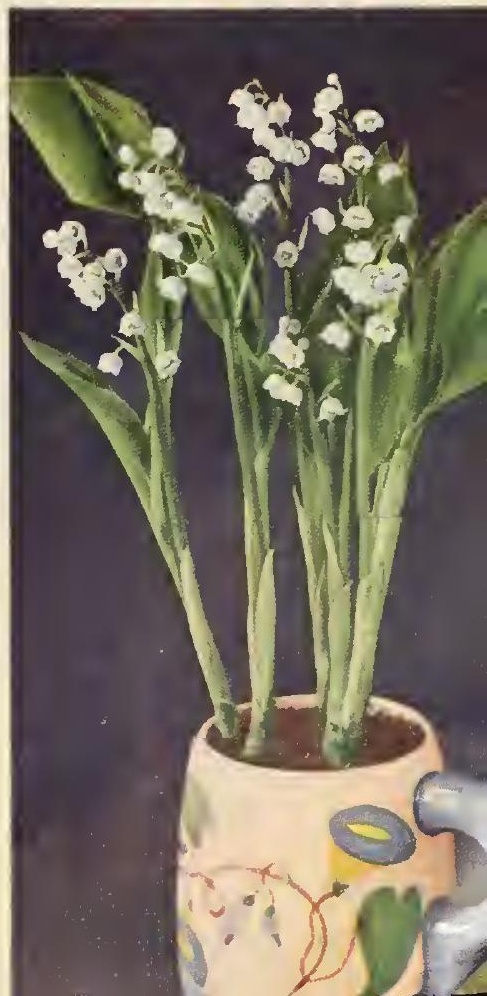


Germain's Califarnia Dahlias

\section{for Spring 1952}

Germainí Twelve Papular Decarative Dahlias

5600 Avalon. Clear lemon yellow flowers on tall strong stems.

5601 Blue River. Distinct deep lilac or bluish mauve, the nearest to be had in a blue Dahlia.

5602 Mrs. George Le Boutillier. Handsome 10 inch blooms of rich velvety crimson, excellent

5603 Golden Eclipse. Golden yellow with slight blush of salmon. Rich salmon center.

5604 Jane Cowl. An old favorite, but still one of the best of the autumn shades. Huqe flowers
of golden buff, suffused salmon and rose pink.

5605 Jersey Beauty. Another old timer of qreat popularity. Considered by many to be the best popularity Conside.

5606 Jean Kerr. A very fine medium sized Dahlia of pure white and good substance. The

5607 Le Toreador. Large bright red flowers borne on tall stiff stems. One of the best red Dahlias.

Above all priced alike: 59c each; 3 for \$1.69: 6 for \$3.29; 12 for $\$ 5.49$.

COLLECTION: 5612. One each of the above 12 varieties. For only $\$ 5.25$.

COLLECTION: 5614. Two each of the aboye 12 yarieties. For only $\$ 10.00$

\section{Germain's Cactus Dahlias}

5580 Beaute. A striking Flower of clear lemon yellow. A profuse bloomer.

5581 Cometeer. Another popular Dahlia of light bronze shading to gold and buff.

5582 Governor Heil. Bright orange suffused pink and gold at the center.

5583 Jersey Dainty. Snow white flowers with creamy centers.

5584 Pink Giant. Large flowers of clear pink. 5585 Rose Beauty. Medium sized flowers of a rich deep rose. One of the best.

5586 Ruby King. Deep Ruby Red flowers. Do not fade or burn.

5587 Germain's Lavender. $\AA$ beautiful cactus Dahlia in clear lavender shades. A wonderful All priced alike: $69 \mathrm{c}$ each; Three for $\$ 1.89$ Six for \$3.69; 12 for $\$ 7.29$.

COLLECTION No. 5588. One each of the above 8 Cactus
all for only $\$ 4.25$.

COLLECTION No. 5590. Two each of the above 8 Cactus Dahlias. Sixteen tubers in all for only $\$ 8.00$
5608 Watchung Giant. Extremely larqe blooms of deep amber suffused orange. $\bar{A}$ winner at all

5609 Major Bowes. Huge flowers of delicate deep pink. A viqorous qrower.

5610 Mrs. Wm. Knudsen. The best $w$ hite Dahlia for cutting, exhibition or qarden.

5611 Town Topics. Medium sized flowers of deep purple. The petals are often tipped white,
which forms a striking contrast.

\section{GERMAIN'S DECORATIVE}

DAHLIA COLLECTION No. 5594

One tuber each of Blue River, Golden Eclipse, Jane Cowl, Le Toreador, Major Bowes and Mrs. Wm. Knudsen. Six bulbs for only $\$ 2.89$.

\section{GERMAIN'S CUT FLOWER}

\section{DAHLIA COLLECTION No. 5592}

Six superb Dahlias suitable for cut flowers or show. One each of Ayalon, Jean Kerr, Jersey Beauty, Rose Beauty, Mrs. George Le Boutillier and Fireball for only $\$ 2.89$.

\section{Ball Type ar Sham Dahlias}

One of the most attractive types of Dahlias. The alants are sturdy. The formal ball-shaped flowers 5615 Snowball. Flower of medium size. Pure

5616 Rosy Dawn. Golden yellow with fine shadings of salmon. Golden yellow

5618 Parthos. Deep Red.

5619 Clara Clemens. Two tone red and white.

The above Dahlias are all Priced Alike.

59c each; 3 for $\$ 1.69 ; 6$ for $\$ 3.29 ; 12$ for $\$ 6.49$. BALL OR SHOW DAHLIA COLLECTION No. 5660

One bulb each of the fiye yarieties listed aboye for only $\$ 2.50$, Postpaid.

\section{BARGAIN COLLECTION OF GIANT FLOWERED DAHLIAS}

Our selection from those varieties we mahave in surplus when your order is filled. Dahlias at real barqain prices.

5640 l tuber each, 6 varieties only $\$ 2.50$ 56452 tubers each, 6 varieties only $\$ 5.00$

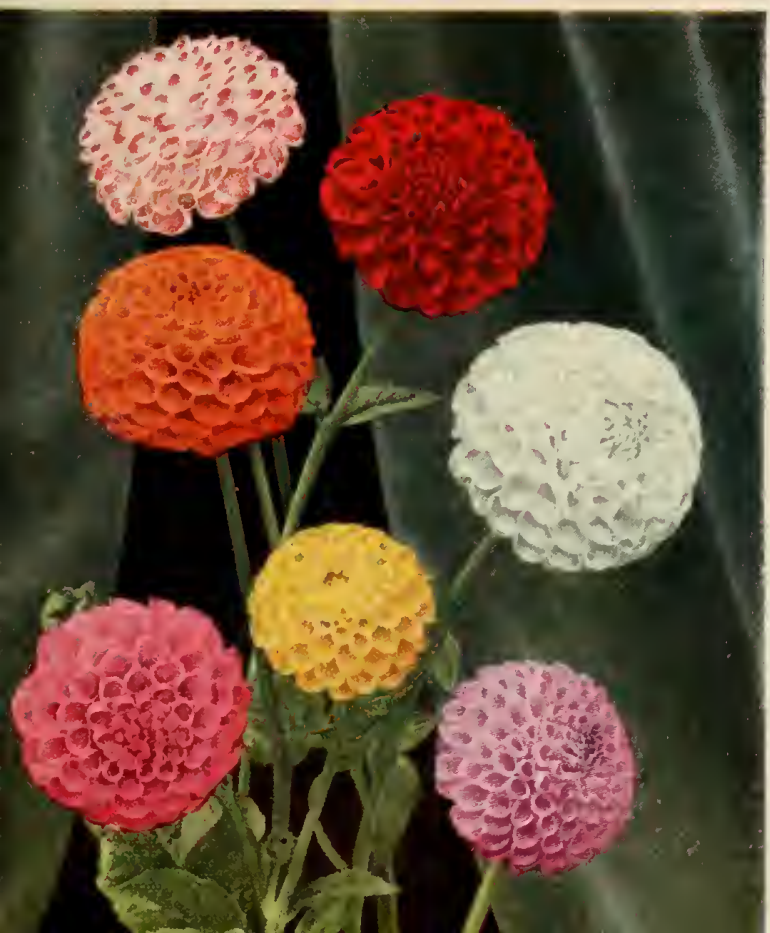

\section{Six Chaice 4 Pampan Dahlias}

These small ball shaped Dahlias are excellent cut flowers, like the miniature Dahlias they bloom

5628 Yellow Gem. Pure white.

5629 Snow Clad. White.

5630 Morning Mist. A beautiful shade Lilac.

5631 Mary Munns. Clear lavender. 5632 Little Herman. Red and white. 5633. Cardinal. Bright red.

All priced alike at 49c each; 3 for $\$ 1.39$; 6 for $\$ 2.69 ; 12$ for $\$ 5.19$.

\section{GERMAIN'S POMPON} DAHLIA COLLECTION

No. 5634-One each of the six Pompon Dahlia yarieties listed aboye for only

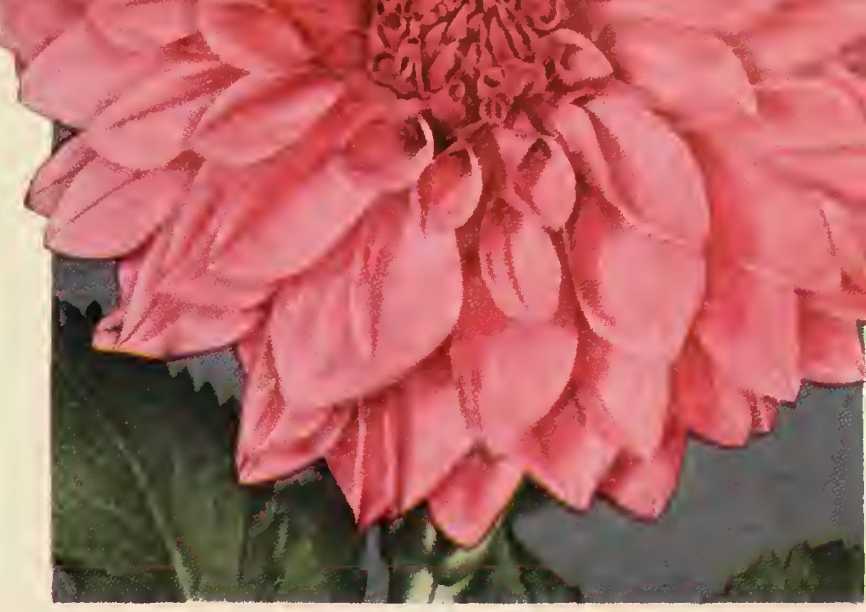

MAJOR BOWES

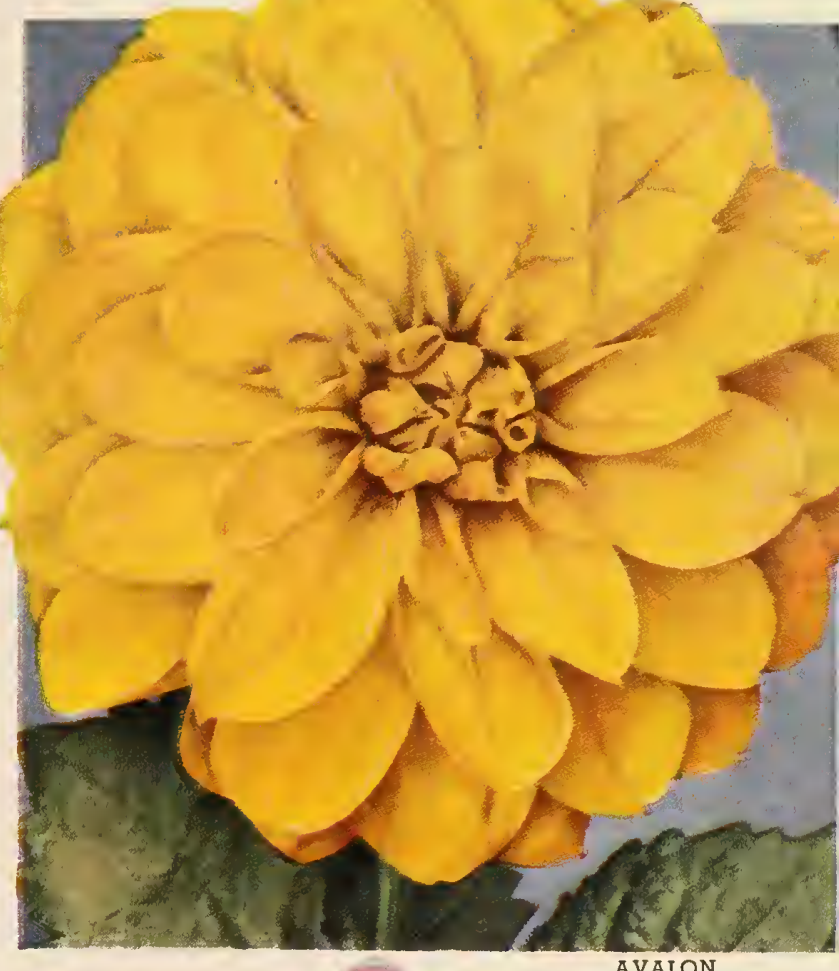

BLUE RIVER

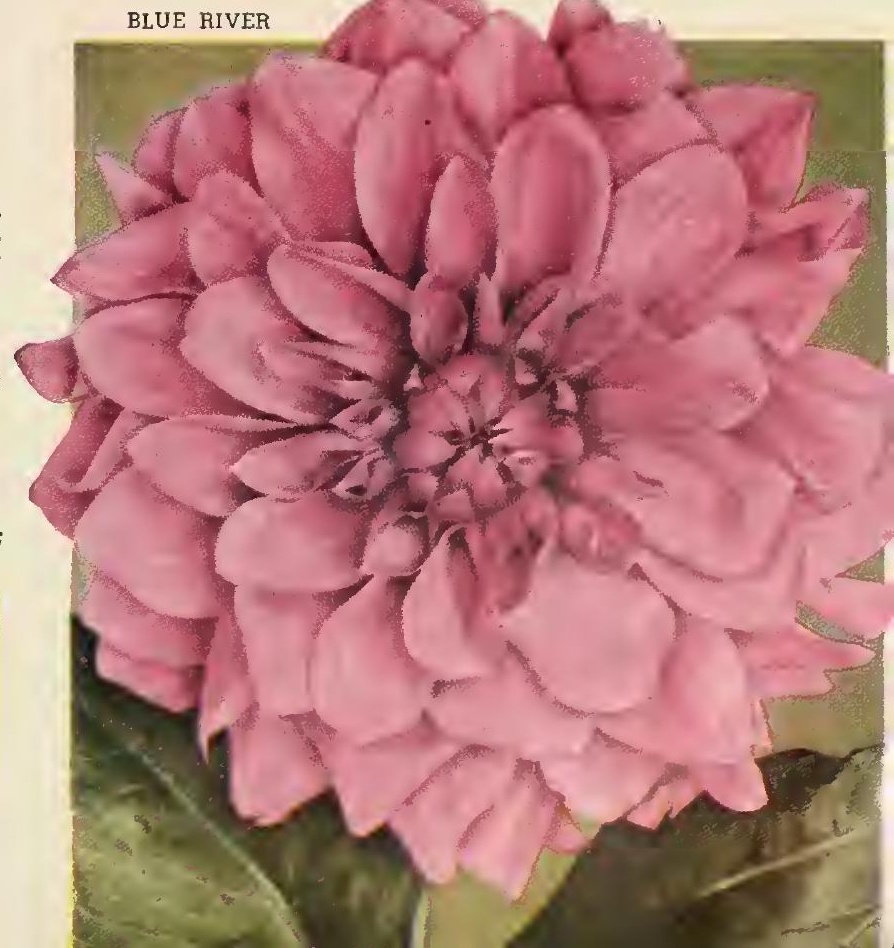




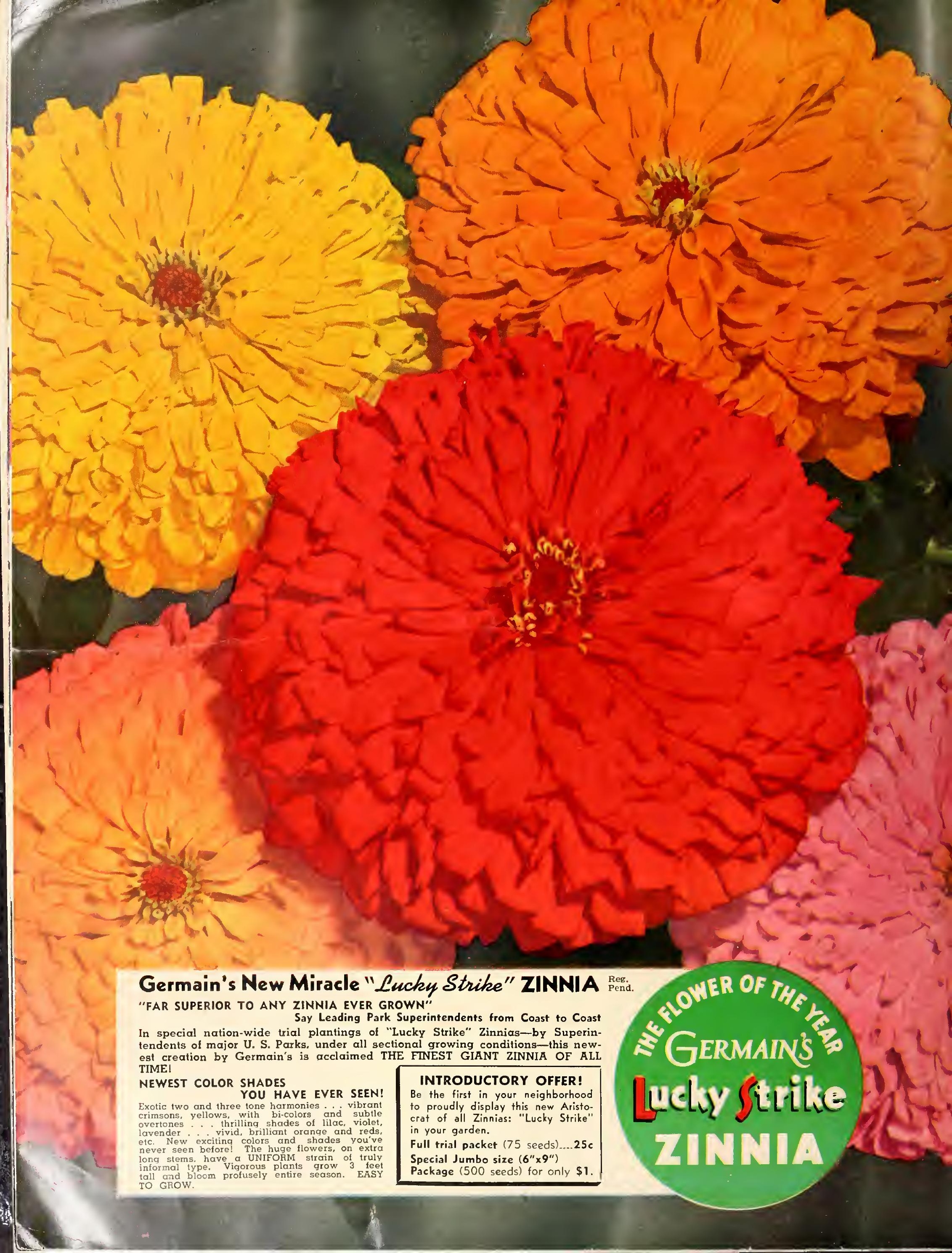

